\title{
Estimating Wetland Condition Locally: An Intensification Study in the Blackfoot and Swan River Watersheds
}

\author{
Prepared for: \\ The U.S. Environmental Protection Agency \\ Prepared by: \\ Melissa Hart, Linda Vance, Karen Newlon, Jennifer Chutz, and Jamul Hahn \\ Montana Natural Heritage Program \\ a cooperative program of the \\ Montana State Library and the University of Montana
}

December 2015

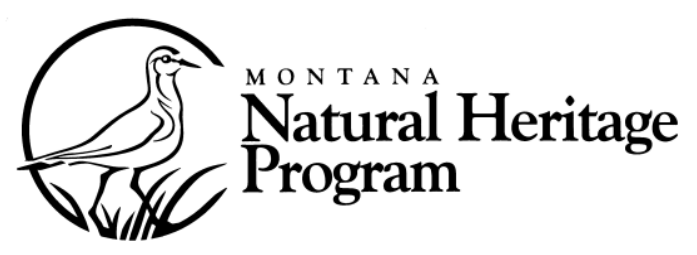




\title{
Estimating Wetland Condition Locally: An Intensification Study in the Blackfoot and Swan River Watersheds
}

\author{
Prepared for:
}

The U.S. Environmental Protection Agency

Agreement Number:

CD-96814001-0

Prepared by:

Melissa Hart, Linda Vance, Karen Newlon, Jennifer Chutz, and Jamul Hahn
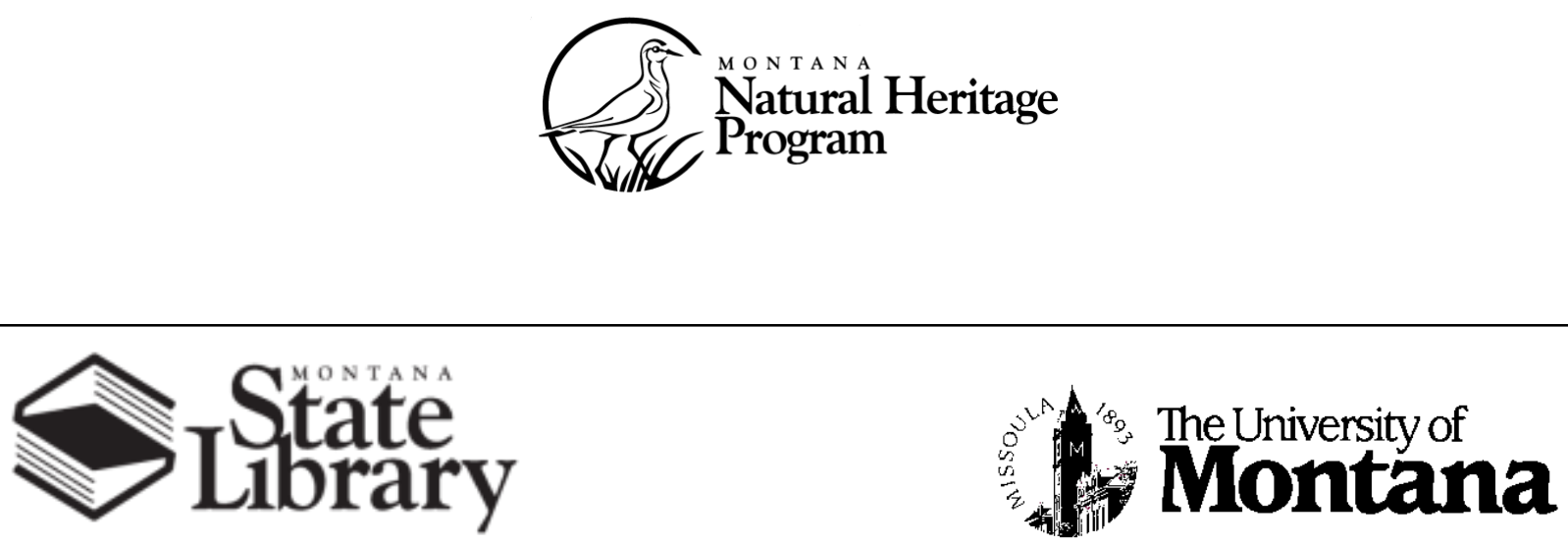

C2015 Montana Natural Heritage Program

P.O. Box $201800 \bullet 1515$ East Sixth Avenue • Helena, MT 59620-1800 • 406-444-5354 
This document should be cited as follows:

Hart, Melissa, Linda Vance, Karen Newlon, Jennifer Chutz, and Jamul Hahn. 2015. Estimating Wetland Condition Locally: An Intensification Study in the Blackfoot and Swan River Watersheds. Report to the U.S. Environmental Protection Agency. Montana Natural Heritage Program, Helena, Montana. 52 pp. plus appendices. 


\section{EXECUTIVE SUMMARY}

This report summarizes the results of our fourth statewide rotating basin assessment, focusing on wetlands in the Blackfoot and Swan subbasins of western Montana. We assessed wetland condition within nine watersheds at multiple spatial scales. We conducted Level 1 GIS analyses that produced: 1) wetland landscape profiles, which summarize information on wetland abundance, type, and extent within a given watershed; and 2) a landscape characterization, which characterizes the anthropogenic stressors such as roads and land uses, as well as general information regarding wetland landscape context, using readily available digital datasets. We carried out Level 2 assessments to provide rapid, field-based assessments of wetland condition based on four attributes: 1) Landscape Context; 2) Vegetation; 3) Physicochemical; and 4) Hydrology. Finally, Level 3 intensive assessments provided detailed information on the structure and composition of wetland vegetation at a subset of sites. This multi-tiered framework allows for the incorporation of multiple scales of assessment, integrating landscape-level information, ambient wetland condition, and site-specific data.

We included all digitally mapped wetlands to produce wetland landscape profiles for the project area. For the Level 1 landscape characterization and Level 2 and Level 3 wetland assessments, the target population included all mapped palustrine wetlands greater than 0.1 ha. We followed a spatially balanced sampling approach to select wetlands for assessment.

For Level 1 values and Level 2 assessment scores, we calculated descriptive statistics and assessed the range and distribution of each metric by examining frequency histograms. For Level 3 assessments, we calculated multiple vegetation metrics to conduct a floristic quality assessment (FQA). The FQA accounts for the presence of both native and exotic species, as well as individual plant species' tolerance of disturbance. We determined the relationships between Level 3 vegetation metric values, Level 2 assessment scores, and stressors recorded at assessment sites by examining Spearman's correlation coefficients.

Based on digital mapping, wetlands and other water bodies within the study area totaled 97,847 acres $(39,597$ hectares). The majority $(76 \%)$ of the mapped acres are palustrine wetlands. These totals include deepwater areas such as lakes and river channels, which provide critical aquatic habitat and other valuable ecosystem services, but are not considered wetlands.

We conducted a Level 1 landscape characterization of 1,000 mapped palustrine wetland polygons at three spatial scales, examining our recently developed Human Disturbance Index (HDI) within 100-m, 300-m, and 1,000-m envelopes around each polygon. Mean HDI scores were relatively consistent across all three scales for wetland types in the Blackfoot and Swan subbasins, suggesting moderate levels of disturbance. When scores were calculated separately for surveyed and non-surveyed (randomly chosen) wetlands, results suggested a public land effect: 1) randomly chosen wetlands had lower mean HDI scores for public than for private lands, whereas surveyed wetlands - tending to be nearer roads - showed no statistically significant difference between public and private lands; and 2) across all wetland sites, mean 
HDI scores were lower for surveyed sites (which tended to be on public land) than they were for randomly selected sites.

We visited 126 sites during the summer of 2013 and 2014, sampling 24 probabilistic sites and 26 targeted sites with the MTNHP Level 3 EIA protocol, and the rest with the Level 2 protocol. The Intermontane Prairie Pothole was the most common system sampled (37 sites). Rocky Mountain Subalpine-Montane Fen was the second most commonly sampled ecological system (26). Other systems encountered in this study included Alpine-Montane Wet Meadow, Western North America Emergent Marsh, Wooded Conifer Swamp, Rocky Mountain Vernal Pool, and several Riparian Woodland and/or Shrubland systems.

Level 2 condition scores were calculated for all 126 wetlands sampled. Scores ranged from 52100 out of a possible range of 21.5-100. We divided our assessment scores into four categories defined relative to their departure from reference standard. Most sites were either at or near the reference standard, or slightly departed from reference. Thirty-eight sites had no observed stressors in the assessment area (AA), whereas only 17 sites had no observed stressors within the 200-m envelope. No site's impact rating was categorized as Very High. Impact scores tended to be highest for the Landscape Context and Vegetation attributes within both the AA and the 200m envelope (Tables 16 and 17). The Physicochemical attribute made the least contribution to higher impact scores, with nearly all sites falling in the No Impact and Low Impact categories.

Recreation/human visitation and livestock grazing were the most common stressors potentially impacting Landscape Context within the AA, while unpaved roads were the most observed stressor in the 200-m envelope. Vegetation stressors included browsing by native ungulates, livestock grazing, and beaver activity. Beaver activity was also the most common Hydrologic stressor, along with impoundments. Trash or refuse dumping was the most common Physicochemical stressor.

We completed 24 Level 3 intensive assessments within the project area, encountering 309 plant taxa. The average number of species encountered per site was 34 (range 7-76). Of the 282 taxa identified to species, $260(92 \%)$ were native species and $19(7 \%)$ were exotic species. We calculated FQA metrics for all 24 Level 3 assessment sites. Mean C-value across these sites was 4.91 (range $3.44-6.34$ ). Most C-values for native species encountered fell between 3 and 8 (Figure 25). Species at the lower end of that range are found in diverse habitats with little to moderate disturbance, while those at the higher end tend to be habitat specialists or have low tolerance for disturbance.

To understand the effectiveness of this assessment framework in determining the condition of wetlands in the southeast Montana project area, we compared Level 3 assessment results with Level 2 assessment results. Impact ratings within the AA and within the 200-m envelope around the AA showed moderate correlations with overall Level 2 assessment scores. The Landscape Context and Hydrologic attribute scores were most strongly correlated with overall impact rating for both the AA and the 200-m envelope (with $r$ values ranging from 0.35-0.54).

There were 16 vegetation metrics evaluated in the FQA. Most of the vegetation metrics showed some degree of correlation with either stressors or overall wetland condition, but none of the 
correlations was strong. The strongest correlation was observed between mean C-value of native species and overall condition score. Non-native species richness was negatively correlated with stressor impact scores and overall condition scores, meaning that as impact and condition scores increased toward their maximum values (indicating reference conditions on the ground), the number of non-native species decreased.

FQA metrics that were correlated with overall condition scores also were correlated with one or more individual Level 2 attribute scores (Table 24). Not surprisingly, nearly all FQA metrics showed moderate correlation with the Vegetation attribute. Again, non-native species richness was negatively correlated with all four attributes, meaning that as EIA attribute scores increased toward 100 (reference conditions), non-native species richness decreased.

Results from this project indicate the wetlands in the Blackfoot-Swan area of Montana are in good to excellent condition. Except for unpaved roads, which are common throughout the study area as a legacy of logging, wetlands are relatively unimpacted by human stressors. However, these unpaved roads often act as sites for weedy species to establish, threatening wetlands and their adjacent buffers.

The rotating basin assessment was complemented by an analysis of data from this and previous projects to evaluate whether water permanence is a predictor of wetland condition. Analysis of the National Wetland Plant List for the Western Mountains and Valleys against the Coefficients of Conservatism (C-values) for Montana wetland plants shows that the mean $\mathrm{C}$-value for OBL and FACW species is 5.83, while for FAC, FACU and UPL species it is 2.87. In this study, we saw a moderate negative correlation $(-0.55)$ between the percentage of FACW or OBL species at a site and its overall native plant richness, and a slightly weaker correlation between the unadjusted Floristic Quality Index (FQI) of native species and the percentage of hydrophytes (-0.45). Scores on the Adjusted Cover-weighted FQI are moderately and positively correlated (0.49) with the proportion of hydrophytes. Examining these factors across several of our rotating basin assessments, we found that Mean $\mathrm{C}$ and Mean $\mathrm{C}$ of native species were moderately correlated with the proportion of FACW and OBL (0.58 and 0.46). We noted, too, that in both cases there was a moderate negative correlation between the proportion of hydrophytes and the number of exotic species. We also saw a moderate correlation between the Adjusted FQI for native species and the proportion of FACW and OBL species at a site. The analysis also showed that while there appears to be a clear relationship between the percent of standing water and proportion of FACW and OBL species, there does not appear to be any linear relationship between the percent of standing water and Mean C, except at the driest sites.

Finally, another goal of this project involved describing an ecological system that has not been previously described in Montana, the Intermontane Prairie Pothole. These sites are relatively abundant in the study area. Using data collected in this study, we were able to produce a detailed Ecological System description characterizing the environment, vegetation, dynamics and restoration considerations for these wetlands. 


\section{ACKNOWLEDGMENTS}

This project was funded by a U.S. Environmental Protection Agency Region 8 Wetland Program Development Grant. We would like to thank Toney Ott of EPA Region 8 for her continued support and commitment to wetland assessment and monitoring in our region. We thank Nick Smith, Karissa Ramstead, Isabel Beaver and Luke Obermeyer for spending long days in the field collecting data for this project. We also thank Robin Lium, Kyla Zaret, Gary Carnefix, Clea Klagstad, Sara Owen and Alexis Buchwald for spending long days in the office mapping wetlands and riparian habitats in the study area. Any errors or omissions in the report are entirely the responsibility of the authors. 


\section{Table of Contents}

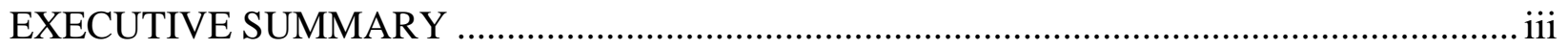

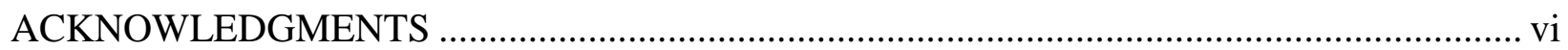

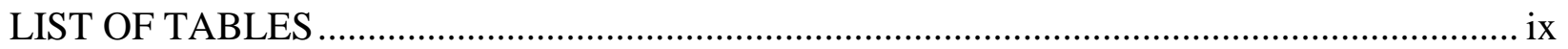

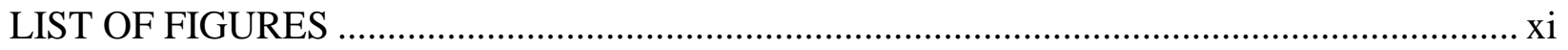

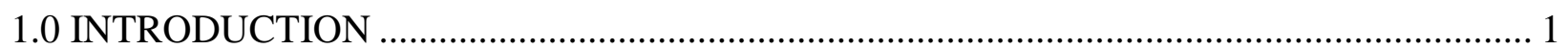

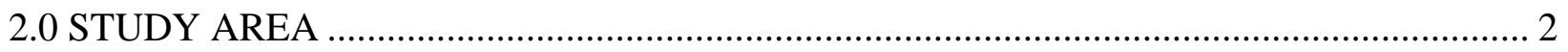

2.1 Geography

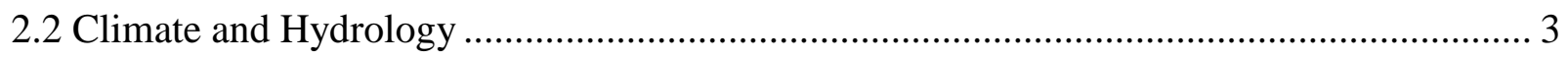

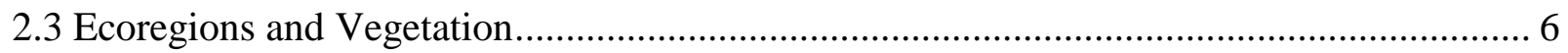

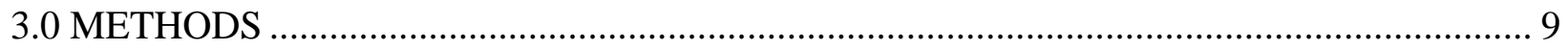

3.1 Ecological Integrity Assessment Framework .................................................................. 9

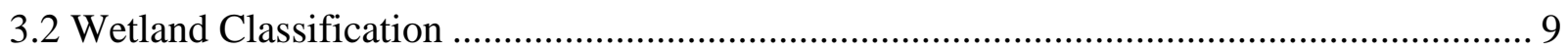

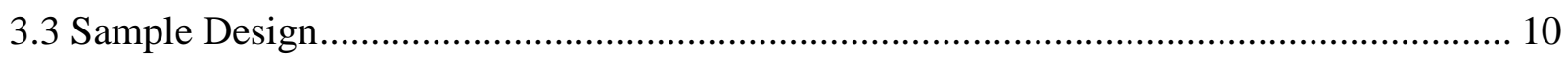

3.4 Level 1-2-3 Assessments ......................................................................................... 11

3.4.1 Level 1 - Wetland Landscape Profiling .................................................................... 11

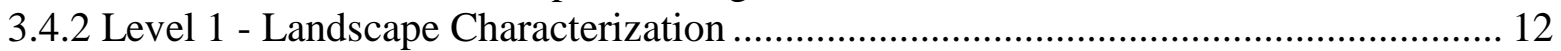

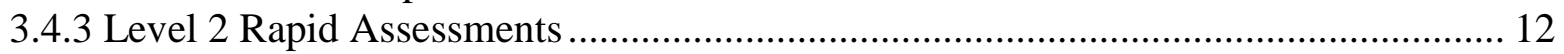

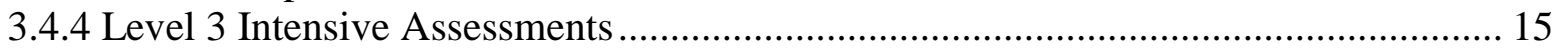

3.4.5 Intensive Assessment of Stressors ...................................................................... 16

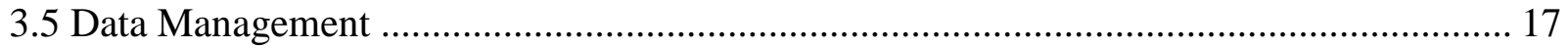

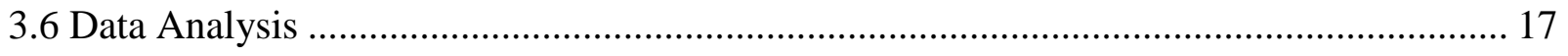

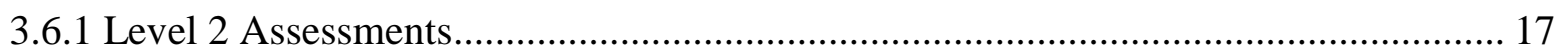

3.6.2 Level 3 Vegetation Assessments ........................................................................... 17

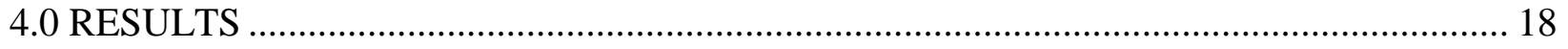

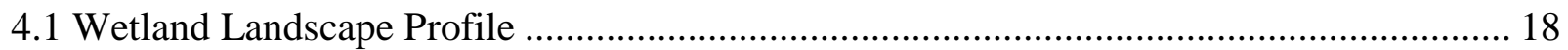

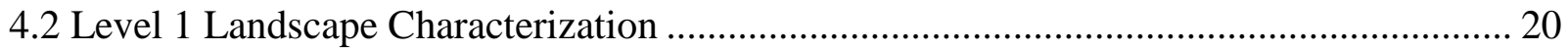

4.3 Level 2 Assessments ............................................................................................... 25

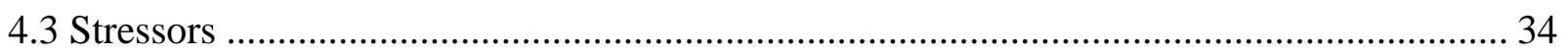

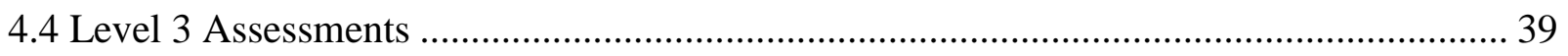

4.5 Floristic Quality Assessment........................................................................................ 40

4.6 Comparisons of Level 2 \& 3 Results .......................................................................... 40

4.7 Intermontane Prairie Pothole Descriptions ....................................................................... 44 
4.8 Wetland Indicator Species and Floristic Quality Assessments ................................... 45

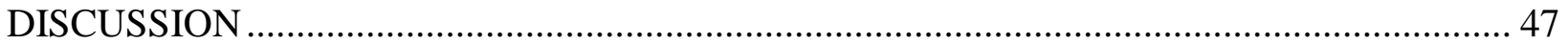

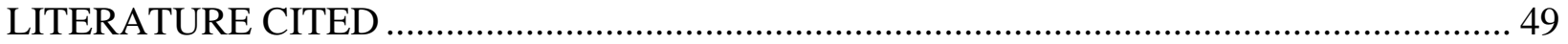

Appendix A. National Wetland Inventory (NWI) attribute codes included in the BlackfootSwan Intensification Project wetland assessment sample frame. ......................................... 53

Appendix B. Palustrine National Wetland Inventory (NWI) attribute codes excluded from the Blackfoot-Swan Intensification Project wetland assessment sample frame. ......................... 54

Appendix C. Lacustrine and riverine National Wetland Inventory (NWI) attribute codes excluded from the Blackfoot-Swan Intensification Project wetland assessment sample frame.

Appendix D. Scoring procedure for calculating stressor impact ratings (sensu Faber-

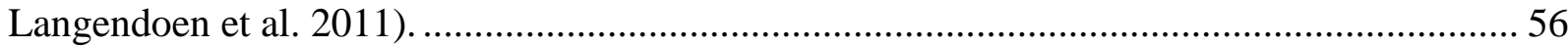

Appendix E. Scoring formulas for Level 2 attribute and overall wetland condition scores..... 57 Appendix F. Terminology, description, and calculation of the floristic quality assessment metrics.

Appendix G. Wetland landscape profile for palustrine wetlands in the Blackfoot-Swan Intensification Project area..... 59

Appendix H. Intermontane Prairie Pothole Ecological System description 


\section{LIST OF TABLES}

Table 1. Land area of watersheds included in the Blackfoot-Swan Intensification Project. ......... 3

Table 2. Level IV ecoregions and their corresponding land area within the Blackfoot-Swan

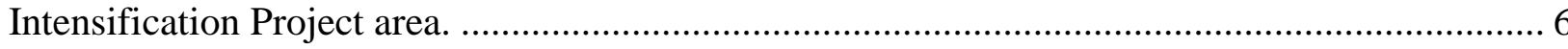

Table 3. Ecological Integrity Assessment metrics and ecological attributes used in the Blackfoot-

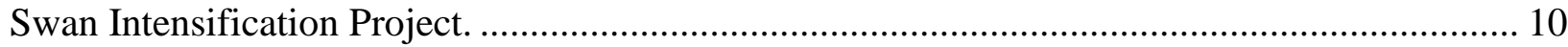

Table 4. Stressor metrics and associated disturbance categories............................................ 13

Table 5. Scope and severity ratings for stressors observed within the assessment area (AA) and

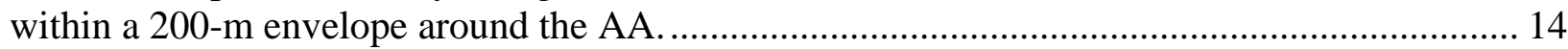

Table 6. Mean, standard deviation (SD), minimum, and maximum values for mean human disturbance index (HDI) by wetland type within $100 \mathrm{~m}, 300 \mathrm{~m}$, and 1,000 m envelopes around Level 2 surveyed wetlands $(n=119)$ and randomly selected wetlands $(n=881)$ in the Blackfoot and Swan subbasins.

Table 7. Comparison of mean human disturbance index (HDI) values within $100 \mathrm{~m}, 300 \mathrm{~m}$, and $1000 \mathrm{~m}$ envelopes around wetland sites under public and private ownership in the Blackfoot and Swan subbasins.

Table 8. Comparison of mean human disturbance index (HDI) values for $100 \mathrm{~m}, 300 \mathrm{~m}$, and $1000 \mathrm{~m}$ envelopes around Level 2 surveyed sites and randomly selected sites.

Table 9. Sampled wetlands by Ecological System in the Blackfoot-Swan Intensification Project area.

Table 10. Sampled wetlands by hydrogeomorphic system in the Blackfoot-Swan Intensification Project area.

Table 11. Wetland condition category by wetland ecological system for 126 sampled wetlands in the Blackfoot-Swan Intensification Project area.. 32

Table 12. Ecological Integrity Assessment (EIA) attribute condition category by wetland ecological system for the Blackfoot-Swan Intensification Project area..

Table 13. Stressors observed in the assessment area (AA) and the 200-m envelope around the AA and the corresponding number of sampled wetland sites, categorized by Ecological Integrity Assessment (EIA) attribute.

Table 14. Count of overall assessment area (AA) stressor impact ratings by wetland ecological system for the Blackfoot-Swan Intensification Project area.

Table 15. Overall stressor impact rating within the 200-m envelope around the assessment area (AA) by wetland ecological system for the Blackfoot-Swan Intensification Project area. .......... 36

Table 16. Ecological Integrity Assessment (EIA) attribute stressor impact rating within the assessment area (AA) by wetland ecological system for the Blackfoot-Swan Intensification Project area. 
Table 17. Ecological Integrity Assessment (EIA) attribute stressor impact rating within the 200$m$ envelope around the assessment area (AA) by wetland ecological system for the BlackfootSwan Intensification Project area.

Table 18. Most commonly encountered plant species during Level 3 intensive assessments in the Blackfoot-Swan Intensification Project area.

Table 19. Means and standard deviations of all floristic quality assessment (FQA) metrics considered by Ecological System for Level 3 assessments completed in the Blackfoot-Swan Intensification Project area.

Table 20. Spearman's correlation coefficients of Impact Category scores calculated within the assessment area (AA) with Level 2 assessment attribute and overall scores.

Table 21. Spearman's correlation coefficients of Impact Category scores calculated within a 200$m$ envelope of the assessment area with Level 2 assessment attribute and overall scores.

Table 22. Spearman's correlation coefficients of metrics included in the floristic quality assessment (FQA) for the Blackfoot-Swan Intensification Project. Correlation coefficients of 0.90 or greater are in bold.

Table 23. Vegetation metrics included in the floristic quality assessment (FQA), and their response to stressors within the assessment area (AA), within the 200-m envelope surrounding the AA, and their relationship with overall wetland condition scores.

Table 24. Spearman's correlation coefficients of floristic quality assessment (FQA) metrics with Level 2 assessment attribute scores for the Blackfoot-Swan Intensification Project.

Table 25. Spearman's correlation coefficients of metrics included in the floristic quality assessment (FQA) for the current study and previous studies in Montana ( $\mathrm{n}=189)$, and with fens excluded $(\mathrm{n}=89)$.

Table 26. Mean $\mathrm{C}$ and proportion of FACW and OBL species by percentage of standing water in the AA. 


\section{LIST OF FIGURES}

Figure 1. Blackfoot-Swan Intensification Project area. ........................................................... 2

Figure 2. Land ownership within the Blackfoot-Swan Intensification Project area.................... 4

Figure 3. Relative effective annual precipitation (REAP) for the Blackfoot-Swan Intensification

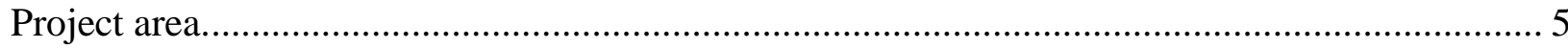

Figure 4. Level IV ecoregions within the Blackfoot-Swan Intensification Project area. ............. 7

Figure 5. Broad land cover and land use classes of the Blackfoot-Swan Intensification Project

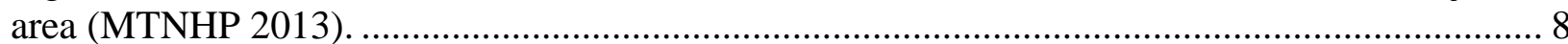

Figure 6. Example plot photos from wetland condition assessments in the Blackfoot-Swan

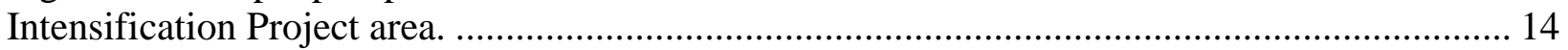

Figure 7. Reléve plot layout (adapted from Peet et al. 1998). .............................................. 16

Figure 8. Percent of mapped wetland acres by Cowardin system in the Blackfoot-Swan Intensification Project area.

Figure 9. Percent of mapped wetland acres by Cowardin class in the Blackfoot-Swan Intensification Project area.

Figure 10. Percent of mapped wetland acres by Cowardin water regime in the Blackfoot-Swan Intensification Project area.

Figure 11. Proportion of mapped wetlands classified as anthropogenically altered by Cowardin system in the Blackfoot-Swan Intensification Project area.

Figure 12. Human disturbance index for the Blackfoot-Swan Intensification Project and surrounding areas.

Figure 13. 126 wetland sites that were sampled for Level 2 assessment in the Blackfoot-Swan Intensification Project area.

Figure 14. Sampled wetlands by land ownership in the Blackfoot-Swan Intensification Project area.

Figure 15. An Intermontane Prairie Pothole sampled as part of the Blackfoot-Swan Intensification Project.

Figure 16. A Western North American Emergent Marsh sampled as part of the Blackfoot-Swan Intensification Project.

Figure 17. A Northern Rocky Mountain Lower Montane Riparian Woodland and Shrubland sampled as part of the Blackfoot-Swan Intensification project. 28

Figure 18. A Northern Rocky Mountain Conifer Swamp sampled as part of the Blackfoot-Swan Intensification project.

Figure 19. A Rocky Mountain Subalpine Shrubland sampled as part of the Blackfoot-Swan Intensification project.

Figure 20. A Northern Rocky Mountain Wooded Vernal Pool sampled as part of the Blackfoot-

Swan Intensification project. 
Figure 21. A Northern Rocky Mountain Subalpine-Montane Riparian Woodland sampled as part

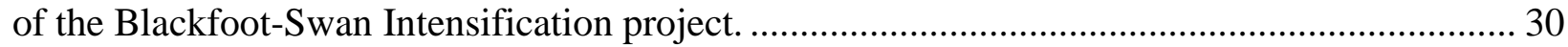

Figure 22. A Rocky Mountain Subalpine-Montane Wet Meadow sampled as part of the Blackfoot-Swan Intensification Project. ........................................................................ 30

Figure 23. A Rocky Mountain Subalpine-Montane Fen sampled as part of the Blackfoot-Swan Intensification project.

Figure 24. Level 2 assessment condition categories for wetlands assessed as part of the Blackfoot-Swan Intensification Project..

Figure 25. Frequency distribution of C-values of native plant species encountered during Level 3 assessments in the Blackfoot-Swan Intensification Project area. 40 


\subsection{INTRODUCTION}

Wetlands provide multiple biological and economic benefits such as plant and wildlife habitat, flood attenuation, groundwater recharge, and improvements to water quality. Despite these benefits, wetlands continue to experience pressures from multiple uses including urban, exurban, and agricultural development, as well as resource extraction. Quantifying the impact of these uses on wetland resources requires scientifically sound metrics to assess wetland condition. Recognizing the need for information on wetland condition at a watershed scale, the Montana Natural Heritage Program (MTNHP) initiated a statewide monitoring and assessment program in 2008 to report on the ambient condition of Montana's wetlands. These basin-wide assessments provide regionally specific information on the ecological integrity of wetlands.

This report summarizes the results of the Blackfoot-Swan Intensification Project (BSIP), our fourth basin-wide assessment of wetlands in the Blackfoot and Swan River watersheds of western Montana. The Blackfoot and Swan watersheds are relatively undeveloped and still support the full suite of native wildlife species, including gray wolf, bull trout, trumpeter swan, and grizzly bear. These watersheds have some of the highest wetland densities in Montana and support a diversity of wetland systems, including forested wetlands, fens, and potholes. Conducting wetland assessments across this range of wetland types will allow us to validate and calibrate our wetland assessment metrics. There are also information gaps about the pothole wetlands left behind by large ice sheets that once covered the intermontane valleys of the region. These potholes support unique and highly diverse plant communities (Lesica 1994), yet no accepted ecological description exists for these systems. Collecting field data, reviewing the literature and developing such a description was an explicit goal of this study.

Our objective was to assess wetland condition within two watersheds in western Montana at multiple spatial scales. We conducted Level 1 GIS analyses that produced: 1) wetland landscape profiles, which summarize information on wetland abundance, type, and extent within a given watershed; and 2) a landscape characterization, which characterizes the anthropogenic stressors such as roads and land uses, as well as general information regarding wetland landscape context, using readily available digital datasets. We conducted Level 2 assessments to provide rapid, field-based assessments of wetland condition, and at a subset of sites, carried out Level 3 intensive assessments to acquire detailed information on the structure and composition of wetland vegetation. This multi-tiered framework allows for the incorporation of multiple scales of assessment, integrating landscape-level information, ambient wetland condition, and sitespecific data.

As part of our ongoing development of wetland assessment tools, we also explored a separate question: when all other things are equal, are Floristic Quality Index scores higher for wetter wetlands than for drier ones? Casual observation and anecdotal evidence suggested that this was the case, in part because wetter wetlands appear to be less susceptible to invasive by exotic species. After several years of conducting rotating basin assessments across the state, we believed we had sufficient data to examine this question empirically. 


\subsection{STUDY AREA}

\subsection{Geography}

The project area is focused within two USGS hydrologic basins in western Montana (Figure 1): Swan River (17010211) and Blackfoot River (17010203).

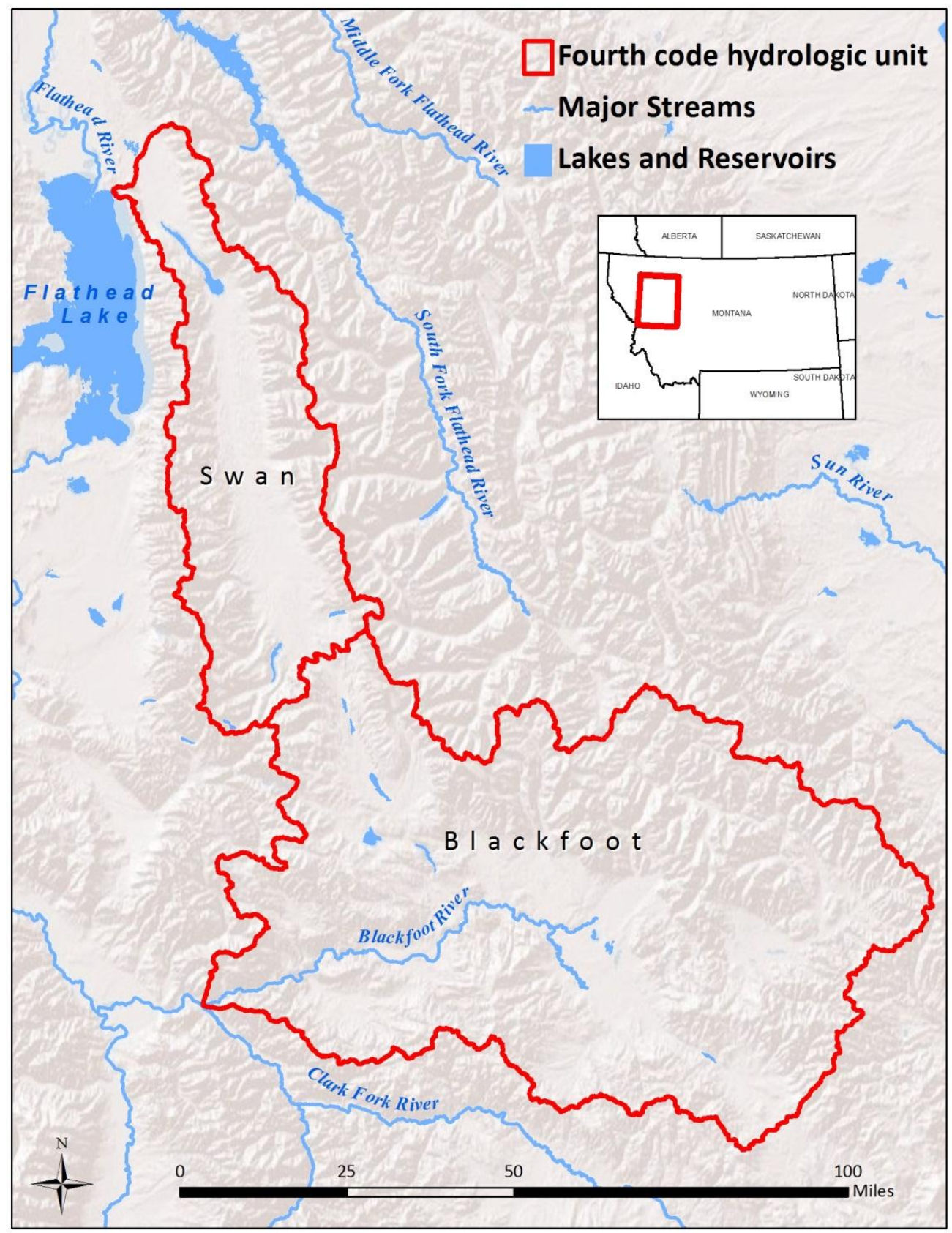

Figure 1. Blackfoot-Swan Intensification Project area. 
The project area covers 1,944,455 ac (786,893 ha) and includes portions of Flathead, Lake, Lewis and Clark, Missoula, Powell, and Granite counties (Table 1). Major towns in the project area include Seeley Lake and Lincoln, with the towns of Bigfork and Bonner on the western periphery and many smaller communities scattered throughout. The area is a complex mix of publicly and privately owned lands; the U.S. Forest Service, the State of Montana, and Bureau of Land Management manage the largest public holdings (Figure 2). Timber harvest and livestock grazing are the historically predominant land uses, with recreation, wildlife habitat, and rural residential development becoming increasingly important.

Table 1. Land area of watersheds included in the Blackfoot-Swan Intensification Project.

\begin{tabular}{lccrc}
\hline Watershed & $\begin{array}{c}\text { 8-digit } \\
\text { hydrologic } \\
\text { unit code }\end{array}$ & Acres & Hectares & $\begin{array}{c}\text { \% } \begin{array}{c}\text { \% of } \\
\text { Area }\end{array} \\
\text { Blackfoot }\end{array}$ \\
Swan & 17010203 & $1,478,394$ & 598,285 & $76 \%$ \\
\hline
\end{tabular}

The topography of the project area, for the most part, has been shaped by glaciation. Continental glaciation yielded the long valley of the Swan, while disintegration of alpine glaciers shaped the hummocky moraines of the Blackfoot Valley. Quaternary alluvial, colluvial, glacial drift, ash deposits, and Precambrian Belt formations are also common. Soils are fine-textured and have low permeability, with many wetlands perched above the water table and receiving most hydrologic inputs from precipitation and runoff.

\subsection{Climate and Hydrology}

The climate of the project area is characterized by long, cold winters and moist springs; in the Swan drainage, climate is partially maritime-influenced. Average annual precipitation ranges from 14.6 to 28.1 inches (37 to $71 \mathrm{~cm}$ ). Peak precipitation periods typically occur in May and June in the Blackfoot, and in November-January in the Swan. Highest maximum daily temperatures occur during July and August, with temperatures averaging $78^{\circ}$ to $83^{\circ} \mathrm{F}$ ( $26^{\circ}$ to $28^{\circ}$ C). (Western Regional Climate Center 2015)

Relative effective annual precipitation (REAP) is an indicator of the amount of moisture available at a given location accounting for precipitation, slope, aspect, and soil properties. REAP ranges widely from 9 inches $(24 \mathrm{~cm})$ to 102 inches $(260 \mathrm{~cm})$, with the lowest values in the Blackfoot valley and highest values along the peaks of the Swan and Mission mountain ranges (Figure 3).

The major river in the project area is the Blackfoot River, which has its headwaters along the Continental Divide at Rogers Pass and flows southwesterly to its confluence with the Clark Fork River just east of Missoula. Other rivers include the Clearwater and Swan Rivers, separated by the gentle Clearwater Divide. The Clearwater flows south through a chain of lakes - including Seeley and Salmon Lakes - into the Blackfoot, and the Swan flows north into Swan Lake and 
empties into Flathead Lake at the town of Bigfork, eventually joining the Flathead River. Other large lakes include Holland, Lindbergh, and Placid Lakes, but the landscape is dotted with many other smaller lakes and wetland features.

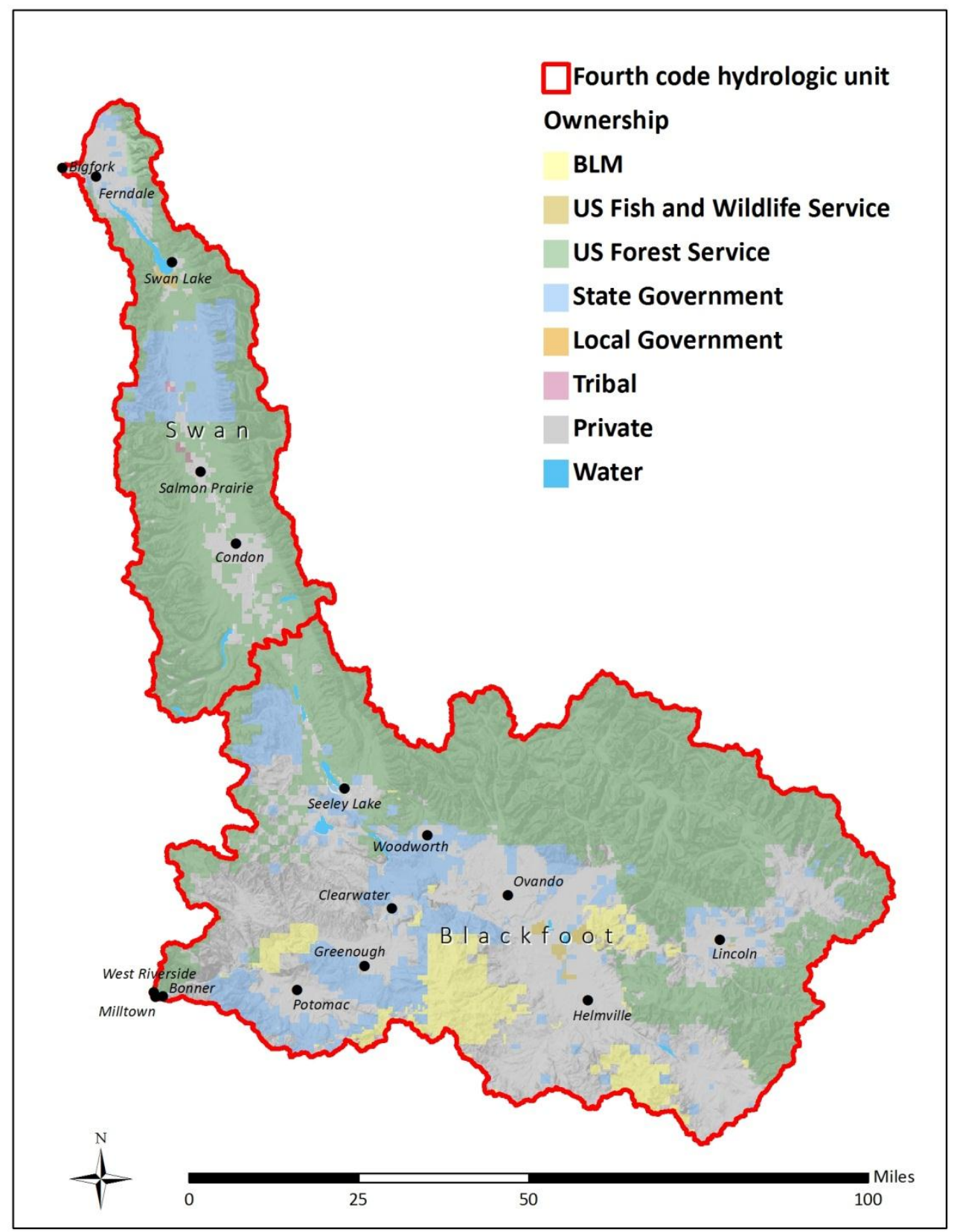

Figure 2. Land ownership within the Blackfoot-Swan Intensification Project area. 


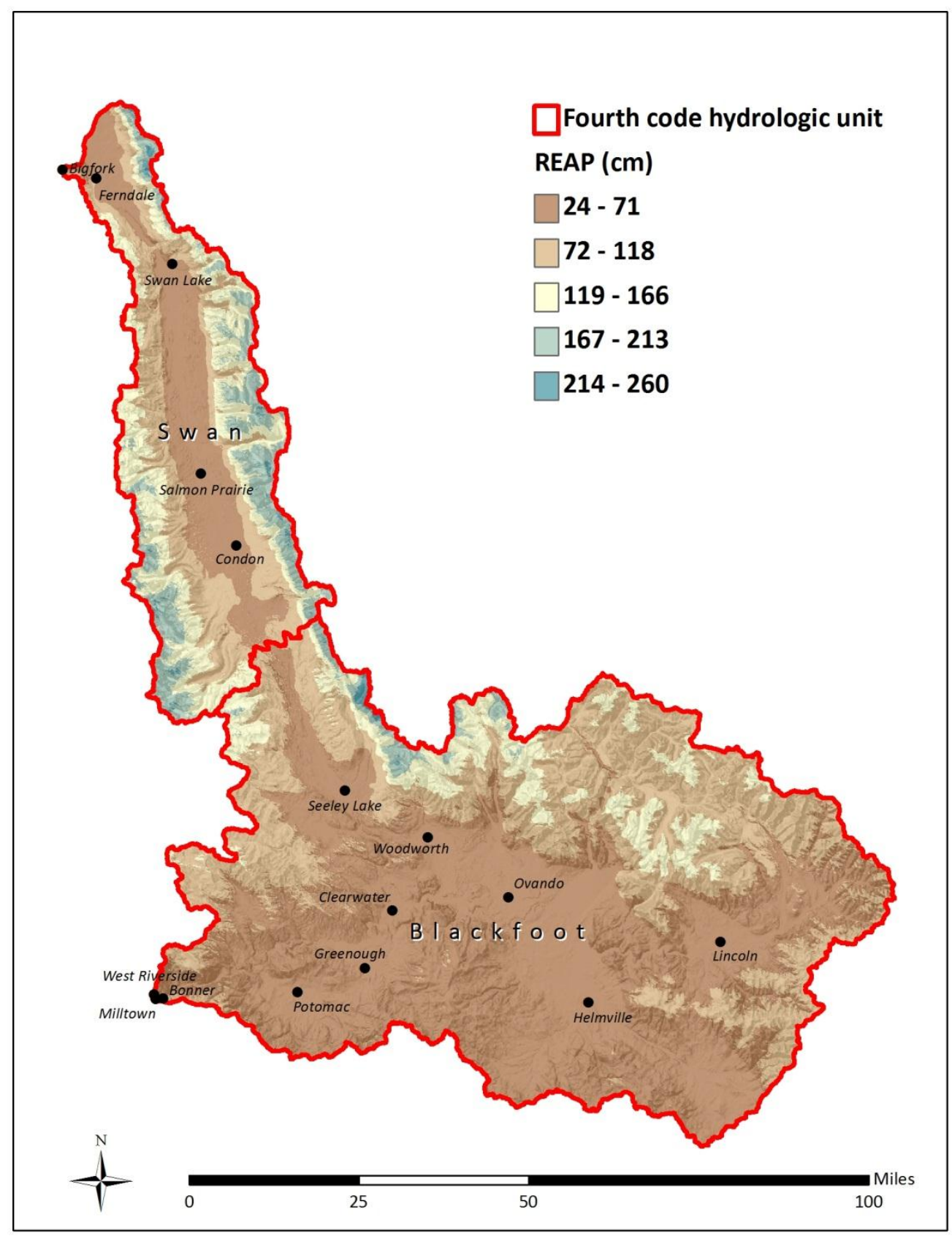

Figure 3. Relative effective annual precipitation (REAP) for the Blackfoot-Swan Intensification Project area. 


\subsection{Ecoregions and Vegetation}

The project area falls within three Level III ecoregions (Omernik 1987). The Blackfoot watershed lies almost entirely within the Middle Rockies ecoregion, although the Swan and Mission mountain ranges in the northwestern corner are assigned to the Canadian Rockies, as they are in the Swan watershed to the north. The valley floor of the Swan falls within the Northern Rockies ecoregion.

Level IV ecoregions further subdivide the area into 12 different units based on geology and dominant vegetation (Table 2; Figure 4). Coniferous trees are the predominant vegetation, with grasslands and shrublands more common in the valleys and foothills of the Blackfoot (Figure 5). Subalpine fir (Abies lasiocarpa), Douglas-fir (Pseudotsuga menziesii), and ponderosa pine (Pinus ponderosa) forests occupy the mountains of the Blackfoot drainage, with foothill prairie vegetation in the Blackfoot Valley. In the moister Mission Mountains and Swan Range and in the valley that separates them, subalpine fir (Abies lasiocarpa) and Douglas-fir (Pseudotsuga menziesii) are joined by grand fir (Abies grandis) and Engelmann spruce (Picea engelmannii).

Table 2. Level IV ecoregions and their corresponding land area within the Blackfoot-Swan Intensification Project area.

\begin{tabular}{llrrr}
\hline Level IV Ecoregion Name & Code & Acres & Hectares & \% Project Area \\
\hline Crestal Alpine-Subalpine Zone & $41 \mathrm{~b}$ & 40,402 & 16,350 & $2.08 \%$ \\
$\begin{array}{l}\text { Deer Lodge-Philipsburg-Avon Grassy } \\
\text { Intermontane Hills and Valleys }\end{array}$ & $17 \mathrm{ak}$ & 77,941 & 31,542 & $4.01 \%$ \\
Eastern Divide Mountains & $17 \mathrm{aj}$ & 10,821 & 4,379 & $\mathbf{0 . 5 6 \%}$ \\
Flathead Thrust Faulted Carbonate-Rich & & & & \\
Mountains & $41 \mathrm{e}$ & 3,295 & 1,333 & $0.17 \%$ \\
Flathead Valley & $15 \mathrm{c}$ & 37 & 15 & $0.00 \%$ \\
Foothill Potholes & $17 \mathrm{p}$ & 159,804 & 64,670 & $8.22 \%$ \\
Rattlesnake-Blackfoot-South Swan- & & & & \\
Northern Garnet-Sapphire Mountains & $17 \mathrm{x}$ & $1,094,864$ & 443,077 & $56.31 \%$ \\
Salish Mountains & 151 & 7,241 & 2,930 & $0.37 \%$ \\
Southern Carbonate Front & $41 \mathrm{~d}$ & 467 & 189 & $0.02 \%$ \\
Southern Garnet Sedimentary-Volcanic & & & & \\
Mountains & $17 \mathrm{al}$ & 32,297 & 13,070 & $1.66 \%$ \\
Stillwater-Swan Wooded Valley & $15 \mathrm{t}$ & 160,331 & 64,884 & $8.25 \%$ \\
Western Canadian Rockies & $41 \mathrm{c}$ & 356,949 & 144,453 & $18.36 \%$ \\
\hline
\end{tabular}




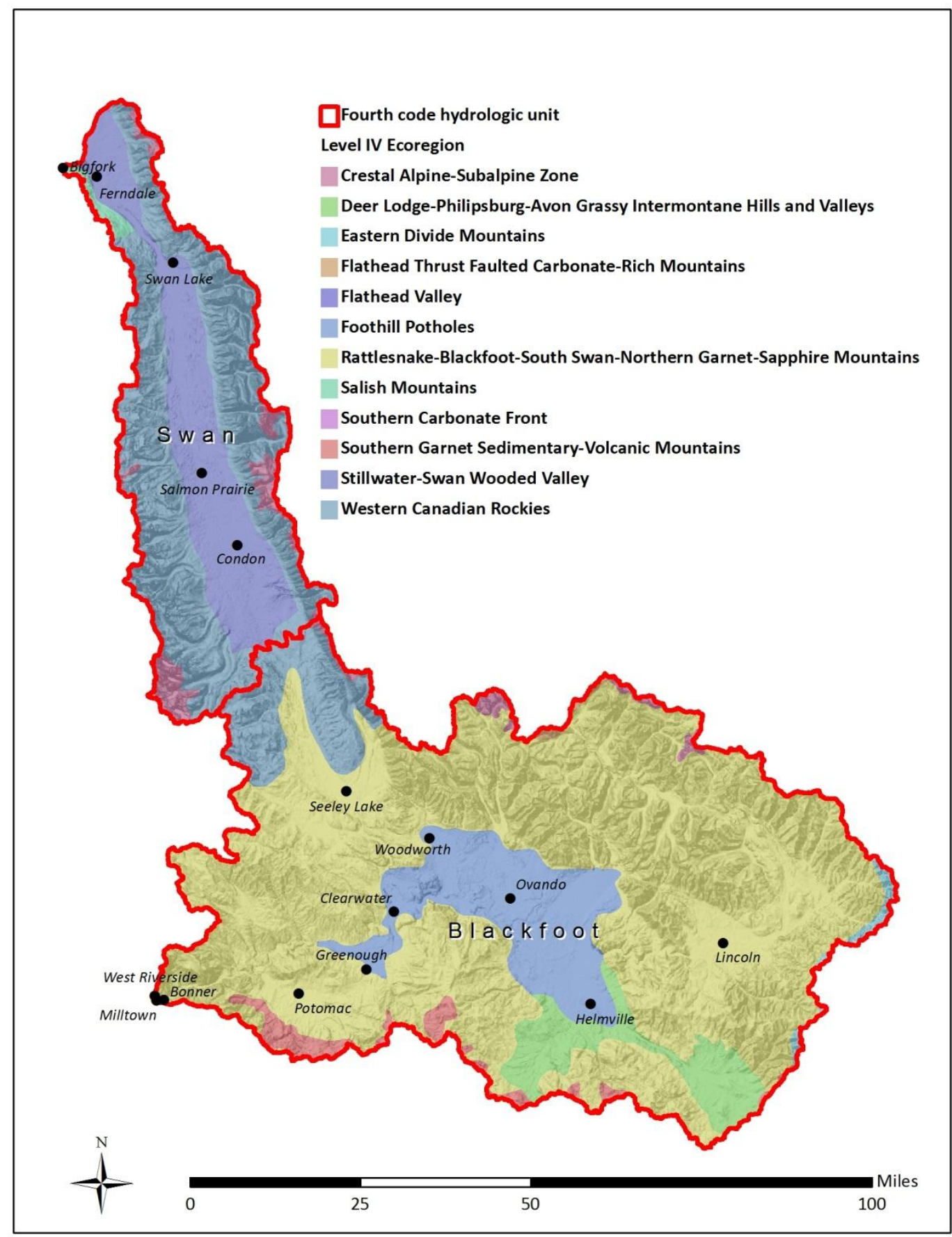

Figure 4. Level IV ecoregions within the Blackfoot-Swan Intensification Project area. 


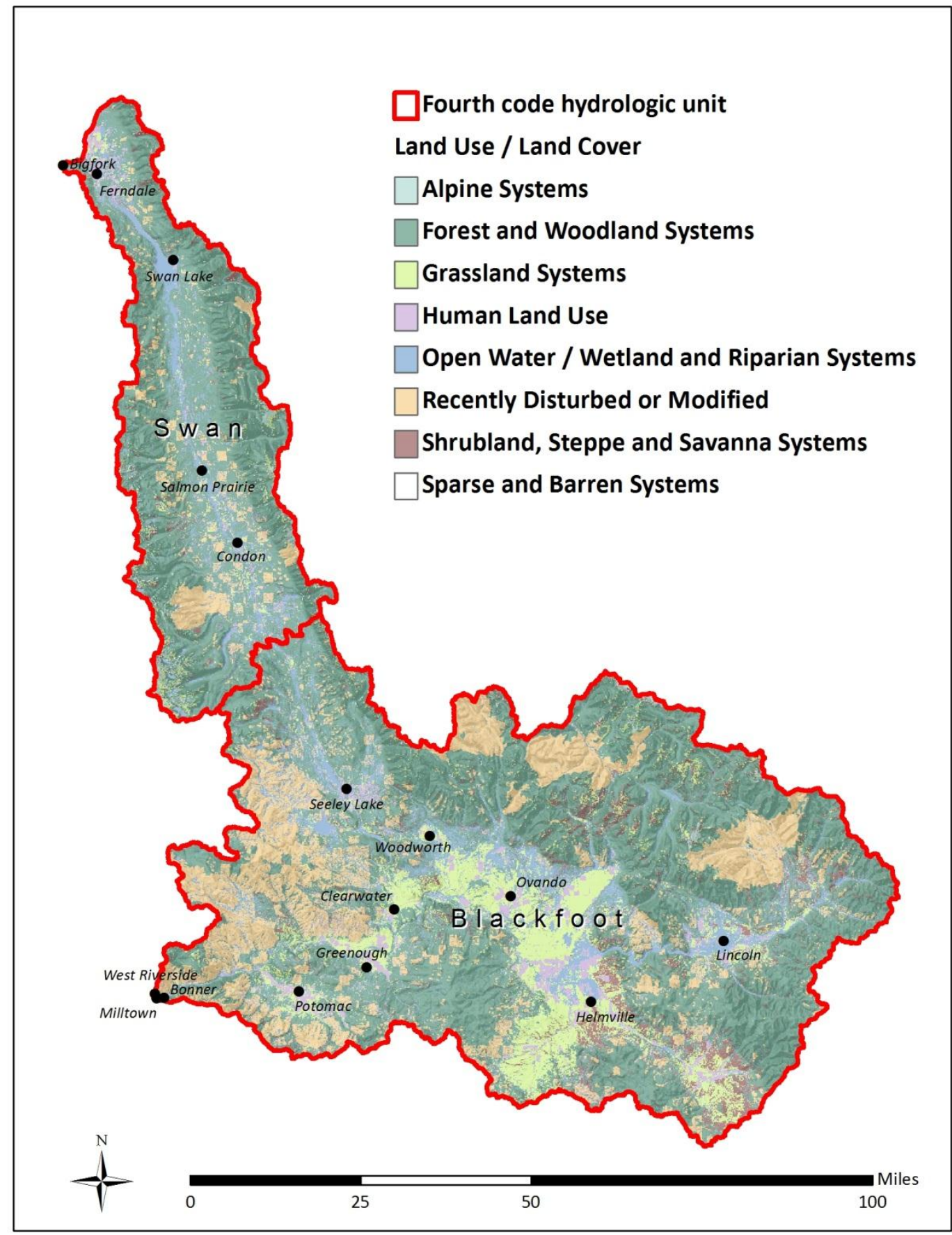

Figure 5. Broad land cover and land use classes of the Blackfoot-Swan Intensification Project area (MTNHP 2013). Areas classified as recently disturbed or modified represent areas burned by wildfires. 


\subsection{METHODS}

\subsection{Ecological Integrity Assessment Framework}

The MTNHP uses an Ecological Integrity Assessment (EIA) framework to assess the condition of wetlands. This EIA framework is based on one developed by NatureServe and ecologists from several Natural Heritage Programs across the country (Faber-Langendoen et al. 2011). This framework also applies concepts from established wetland assessment methods, including the California Rapid Assessment Method for Wetlands (CWMW 2013) and the Ohio Rapid Assessment Method (Mack 2001). An EIA relies upon the identification of key ecological indicators or metrics and stressors that can be readily measured, monitored, or observed. The indicators reflect both the structure and function of the wetland. Metrics consist of narrative ratings and are scaled along a gradient reflecting wetland condition relative to a natural or undisturbed state (i.e., reference standard). Ideally, metrics should be unambiguous, mutually exclusive, and equally distributed along a disturbance gradient, allowing the observer to best describe the observed state (Sutula et al. 2006). Metric ratings are assigned on an ordinal scale, resulting in reduced measurement error and repeatable results. EIA metric ratings are integrated to produce overall scores for four attributes: 1) Landscape Context; 2) Vegetation; 3)

Physicochemical; and 4) Hydrology. The ratings for these four attributes can be combined to produce an overall EIA score (Table 3).

We assessed wetland integrity at three levels. Level 1 GIS landscape analyses consist of: 1) wetland landscape profiles, which use digital wetland mapping to summarize information on wetland abundance, type, extent, and function across the watershed (Johnson 2005); and 2) a landscape characterization of the distribution of anthropogenic stressors such as roads and land use in relation to wetlands, as well as general information regarding wetland landscape context. Level 2 field-based assessments collect data on the general condition of individual wetlands. Level 3 assessments collect detailed quantitative data using indices of biological integrity.

\subsection{Wetland Classification}

Natural variability occurs both within wetland classes (e.g., wet meadows can occur at either alpine or lower montane elevations, but differ in plant diversity and productivity) and among wetland classes (e.g., fens differ in hydrology, soils, and plant communities from freshwater marshes). Providing a classification framework to distinguish wetland systems helps reduce within class variability and enhance detection of differences in condition among wetlands.

Common wetland classification systems include the Cowardin classification system (Cowardin et al. 1979) and the hydrogeomorphic (HGM) classification system (Brinson 1993). Standardized classifications have also been developed through the National Vegetation Classification (NVC; Grossman et al. 1998) and the Ecological Systems classification in the United States (Comer et al. 2003). For the purpose of this project, we used the Ecological Systems classification. This classification system provides a valuable means of classifying wetland systems because it uses 
both biotic (e.g., vegetation physiognomy and floristics) and abiotic (e.g., geologic, hydrologic, elevation, edaphic) criteria to define landscape units. Ecological Systems can be crosswalked to other classification systems including the NVC, Cowardin, and HGM systems. Additionally, they capture the range of natural variability in wetlands while organizing them into manageable conceptual units.

Table 3. Ecological Integrity Assessment metrics and ecological attributes used in the Blackfoot-Swan Intensification Project.

\begin{tabular}{ll}
\hline Attribute & Metric \\
\hline Landscape Context & Landscape Connectivity \\
& Buffer Width \\
& Buffer Length \\
& Buffer Condition \\
Vegetation & Relative Cover of Native Plant Species \\
& Relative Cover of Tolerant Native Plant Species \\
& Relative Cover of Noxious Plant Species \\
& Herbaceous Litter/Woody Debris Accumulation \\
& Interspersion of Plant Zones \\
& Woody Species Establishment and Regeneration \\
& Utilization of Trees and Shrubs \\
& Soil Surface Integrity \\
Physicochemical & Water Quality: Algae, Plants, and Turbidity \\
Hydrology & Water Inputs \\
& Water Outlets \\
& Hydroperiod \\
& Surface Water Connectivity \\
\hline
\end{tabular}

\subsection{Sample Design}

The MTNHP completed digital wetland mapping for the project area based on 2009 and 2013 aerial imagery with funding from this EPA Wetland Program Development Grant and prior funding from agency partners. This digital mapping was used to produce wetland landscape profiles for the project area. For the Level 1 landscape characterization and Level 2 and Level 3 wetland assessments, the target population included all mapped vegetated wetlands, but excluded lacustrine (deepwater lakes), riverine (deepwater habitats contained with the channel), and artificially flooded wetlands from the target population. We also excluded wetlands smaller than 0.1 ha. A list of NWI types included in the sample frame can be found in Appendix A. A list of NWI types excluded from the sample frame can be found in Appendices B and C.

The target number of sample sites was 1,000 wetlands for Level 1 landscape characterization; 100 wetlands for Level 1 and 2 assessments; and 30 wetlands for Level 3 assessment. We 
followed a spatially balanced sampling approach (see Stevens and Olsen 2004, Stevens and Jensen 2007) to select wetlands for assessment. This approach allowed us to account for the spatial patterning inherent in ecological systems (e.g., sites in close proximity tend to be more similar than widely separated sites). Spatially balanced sampling is also more efficient than simple random sampling by minimizing the redundancy inherent in a simple random sample, which might select multiple proximate sites (Stevens and Jensen 2007). The sample design followed a Generalized Random Tessellation Stratified (GRTS) procedure for discrete objects with reverse hierarchical randomization, where polygons within the sample frame were the discrete objects and their locations were identified by their centroids. We selected approximately 1,000 wetlands, stratifying by Level IV ecoregion. GRTS sampling was performed using package spsurvey (Kincaid and Olsen 2009) in R (R Development Core Team 2009). After this initial site selection, we examined each selected wetland using aerial imagery in a GIS to ensure it still existed and was accessible until we had approximately 100 wetlands selected for Level 2 field assessments. We conducted intensive Level 3 assessments at approximately $30 \%$ of these 100 wetlands.

To support the description of Intermontane Potholes, we selected additional targeted sites through visual examination of aerial imagery and wetland mapping. These were confirmed in the field using the following criteria:

1. The wetland must have no hydrologic modifications (e.g., impoundments, ditches, etc.).

2. The HGM class must be Depressional.

3. The wetland should have clear wetland/vegetation zonation.

4. The surrounding upland within $200 \mathrm{~m}$ of the wetland perimeter must be primarily comprised of native prairie (e.g., Festuca idahoensis, F. campestris, Agropyron spicatum) or native sagebrush steppe vegetation (Artemisia tridentata, A. tripartita, and native grasses).

5. The majority of the water in the wetland must be less than 1 meter in depth.

6. There should be no evidence of heavy livestock use in the wetland or the surrounding 200 m envelope around the wetland (e.g., pugging, salt licks, wallows, water holes).

7. If the selected wetland does not meet the above criteria, or is unable to be sampled for other reasons, please note this and select another wetland with a similar hydrologic regime within the 200 meter envelope around the selected wetland.

8. When selecting a different site, try and select a wetland with a similar hydrologic regime to the wetland originally selected.

Thirty-one sites were assessed using Level 3 methods to collect detailed vegetation and hydrologic data; of these, 5 were Intermontane Potholes encountered during the probabilistic surveys and 26 were targeted sites.

\subsection{Level 1-2-3 Assessments}

3.4.1 Level 1 - Wetland Landscape Profiling: Using digital wetland mapping, we prepared a wetland landscape profile for the project area. A wetland landscape profile provides a broad landscape characterization of the wetlands within a particular area at the basin, watershed, or 
subwatershed level. The profile summarizes wetland acreage by: Cowardin system, class, and hydrologic regime; land ownership; and the extent of wetlands that have been anthropogenically altered.

3.4.2 Level 1 - Landscape Characterization: Using our spatially balanced random sample of 1,000 palustrine wetlands from digital wetland mapping, we applied our recently developed Human Disturbance Index (Newlon 2015), to evaluate disturbance characteristics around these selected wetlands at three spatial scales: $100 \mathrm{~m}, 300 \mathrm{~m}$, and $1,000 \mathrm{~m}$.

3.4.3 Level 2 Rapid Assessments: Field methods for Level 2 assessments are detailed in the Montana Ecological Integrity Assessment Field Manual (MTNHP 2014). Level 2 assessments take half a day or less to complete. At each sample wetland point, we established an assessment area (AA) for sampling. The AA was established within a portion of the wetland representing the same Ecological System type within a 0.5 ha area around the sample point. Prior to field visits, we created a set of field maps for each targeted sample point. The field maps outlined the potential AA boundary and multiple radial buffers around the AA. These buffers are used in several of the landscape context metrics.

Once at the target sample point, field team members determined the extent of the AA by estimating the approximate boundaries of the wetland within the potential AA. Readily observable ecological criteria such as vegetation, soil, and hydrological characteristics were used to define wetland boundaries, regardless of whether they met jurisdictional criteria for wetlands regulated under the Clean Water Act (sensu U.S. Army Corps of Engineers 2010). Because certain field metrics vary by Ecological System, every attempt was made to include a single Ecological System in the AA. If the target sample point occurred at the edge of a wetland or at the edge of one Ecological System type, then field teams adjusted the point up to $60 \mathrm{~m}$.

The EIA form also contains a list of observed stressors or disturbances commonly found in Montana (Table 4). Stressor lists can provide additional information when evaluating ecological integrity and can aid in further understanding of overall wetland condition. In some cases, stressors may be present at or near a site, but condition metrics may not reflect these impacts. This may be caused by a temporal lag between the impact and its effect on the biotic community, such as a very recent clear cut, or it may reflect stressors the current biotic metrics do not pick up. In the first case, the stressor list can be used to flag sites that may become degraded in the future. In the second case, the stressor list may indicate that adjustments should be made to the metrics.

Along with recording the occurrence of a stressor, the scope and severity of each stressor were also estimated (Faber-Langendoen et al. 2011; Table 5). Scope is defined as the proportion of the occurrence of an ecosystem that can be expected to be affected by the stress. Severity is the level of damage to the site from the stressor that can be expected with continuation of current circumstances. Stressor scope and severity scores are rolled up into an overall stressor impact score (Appendix D). 
Table 4. Stressor metrics and associated disturbance categories.

\begin{tabular}{|c|c|}
\hline Transportation Disturbances & Land Use Disturbances-Vegetation Removal \\
\hline Paved surfaces (e.g., roads, parking lots) & Chemical vegetation control \\
\hline Unpaved roads & Evidence of intentional burning \\
\hline Railroads & Vegetation conversion \\
\hline & Mechanical vegetation removal \\
\hline $\begin{array}{l}\text { Land Use Disturbances-Development or } \\
\text { Recreation }\end{array}$ & Natural or Environmental Disturbances \\
\hline Domestic or commercial development & Beetle-killed Pinus species \\
\hline Intensively managed sports fields, golf courses & Other diseased conifers \\
\hline Recreation or human visitation & Evidence of recent fire ( $<5$ years) \\
\hline Filling or dumping of sediment or fill & Beaver activity \\
\hline Trash or refuse dumping & Evidence of prolonged drought \\
\hline & $\begin{array}{l}\text { Browsing of woody vegetation by native } \\
\text { ungulates }\end{array}$ \\
\hline Hydrologic Disturbances & Land Use Disturbances-Agriculture \\
\hline Upstream spring box & Dryland farming \\
\hline Impoundment of flowing water & Livestock grazing \\
\hline Potential for agricultural runoff & Irrigated cropland \\
\hline Potential for urban runoff & Irrigated hay pasture \\
\hline Upstream dam & Permanent tree plantation \\
\hline Reservoir/Stock pond & Disturbed fallow lands dominated by exotic \\
\hline Weir or drop structure & species \\
\hline Dredged inlet/outlet channel & Haying of native grassland \\
\hline Engineered channel (e.g., riprap) & Fallow fields (no human use in past 10 years) \\
\hline $\begin{array}{l}\text { Pumps, diversions, or ditches that move water into } \\
\text { wetland }\end{array}$ & Plowing or discing \\
\hline $\begin{array}{l}\text { Pumps, diversions, or ditches that move water out } \\
\text { of wetland }\end{array}$ & Irrigation ditches \\
\hline \multirow{3}{*}{$\begin{array}{l}\text { Berms/dikes/levees } \\
\text { Culverts }\end{array}$} & Fences \\
\hline & Land Use Disturbances-Resource Extraction \\
\hline & $\begin{array}{l}\text { Gravel pits, open pit mining } \\
\text { Other mining activity or abandoned mines } \\
\text { Resource extraction (oil and gas) } \\
\text { Intensive logging ( } 50-75 \% \text { trees of }>50 \mathrm{~cm} \\
\text { diameter removed) } \\
\text { Selective logging }(<50 \% \text { of trees }>50 \mathrm{~cm} \\
\text { diameter removed) }\end{array}$ \\
\hline
\end{tabular}


Table 5. Scope and severity ratings for stressors observed within the assessment area (AA) and within a 200-m envelope around the AA.

\begin{tabular}{cl}
\hline Scope of Disturbances \\
\hline 5 & Pervasive - Affects nearly all $(>75 \%)$ of the envelope or AA. \\
4 & Large - Affects most $(>50-75 \%)$ of the envelope or AA. \\
3 & Moderate - Affects much $(>25-50 \%)$ of the envelope or AA. \\
2 & Restricted - Affects some $(>10-25 \%)$ of the envelope or AA. \\
1 & Small - Affects a small $(1-10 \%)$ portion of the envelope or AA. \\
0 & Nil - Little or no observed effect $(<1 \%)$ on the envelope or AA. \\
\hline Severity of Disturbances & Extreme - likely to extremely modify, degrade, destroy, or eliminate the wetland. \\
3 & Serious - likely to seriously modify, degrade or reduce wetland function or condition. \\
2 & Moderate - likely to moderately modify, degrade or reduce wetland function or \\
1 & condition.
\end{tabular}

In addition to the EIA indicator metrics and observed stressors, we also collected standard site variables at each sample location. These included:

- UTM coordinates

- Elevation, slope, and aspect

- Ecological System classification (Comer et al. 2003)

- Dominant plant species

- HGM classification (Hauer et al. 2002)

- Cowardin classification (Cowardin et al. 1979)

- Nearby landforms (alluvial fans, narrow bedrock valley, alluvial valley, etc.)

- Description of onsite and adjacent ecological processes and land use

- Description of general site characteristics and a site drawing

- Selected soils data: depth and identification of soil horizons, texture, and color

- Water table depth

At least four photos were taken from the AA center at each site (Figure 6). Photos were taken $90^{\circ}$ from each other, and the aspect was recorded to the nearest $5^{\circ}$ at all photo points. Photo placards were placed in the corner of each photo. Additional photos were taken as needed to document the wetland and surrounding landscape.

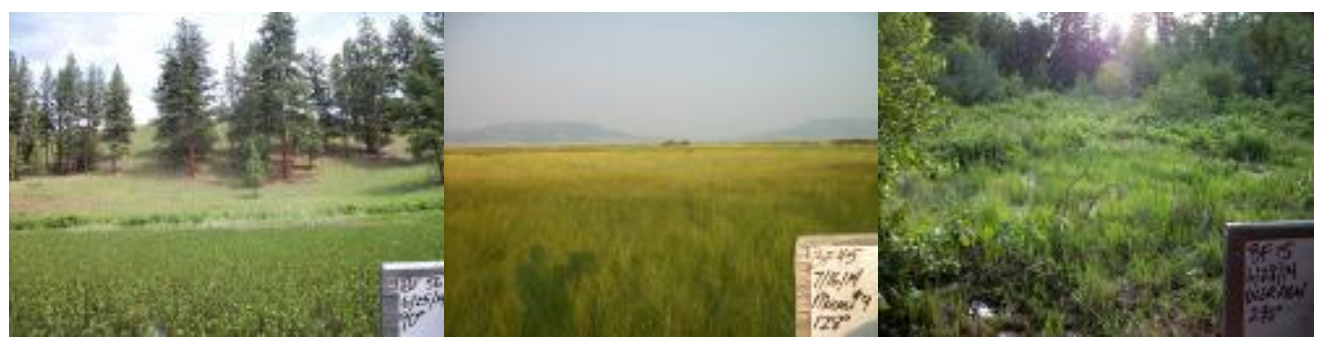

Figure 6. Example photos from wetland condition assessments in the Blackfoot-Swan Intensification Project area. 
At each sampling location, we collected detailed soil data by excavating a soil pit $45-60 \mathrm{~cm}$ in depth. For each horizon, we recorded depth, soil layers, matrix color, redoximorphic feature color and abundance (\%), and soil texture. Soil color was determined using Munsell Soil Color Charts (Munsell Color Company 2000).

3.4.4 Level 3 Intensive Assessments: Field methods for Level 3 assessments are detailed in the Montana Ecological Integrity Assessment Field Manual (MTNHP 2014). We collected intensive Level 3 vegetation data at approximately $30 \%$ of randomly selected and at 26 targeted sites using a $20 \mathrm{~m}$ x $50 \mathrm{~m}$ relevé plot (Peet et al. 1998). This method, which takes approximately six hours per site, has been in use by the North Carolina Vegetation Survey for 15 years (Peet et al. 1998) and has been used to successfully develop a vegetation index of biotic integrity (VIBI) in Ohio (Mack 2004) and Colorado (Rocchio 2006; Rocchio 2007; Lemly and Rocchio 2009). The structure of the plot consists of ten $10 \mathrm{~m}$ x $10 \mathrm{~m}\left(100 \mathrm{~m}^{2}\right)$ modules typically arranged in a $20 \mathrm{~m} \mathrm{x}$ $50 \mathrm{~m}$ array (Figure 7). The plot was subjectively placed within the AA to maximize abiotic/biotic heterogeneity. Capturing heterogeneity within the plot ensures adequate representation of local variations produced by hummocks, water tracks, side-channels, pools, wetland edge, microtopography, etc. The following guidelines were used to determine plot locations within the AA:

- The plot was located in a representative area of the AA that incorporates as much microtopographic variation as possible.

- If the AA was homogeneous and there was no direction or orientation evident in the vegetation, the plot was laid out to run either N-S or E-W using the second hand on a watch to randomly determine direction $(00-29 \mathrm{sec}=\mathrm{N}-\mathrm{S}$ orientation; $30-59 \mathrm{sec}=\mathrm{E}-\mathrm{W}$ orientation).

- If the AA was not homogeneous, was oddly shaped, or was directional (i.e., followed a stream), the plot was oriented to adequately represent all wetland features.

- If the wetland had an irregular shape and the $20 \mathrm{~m} \times 50 \mathrm{~m}$ plot did not fit within the AA, the array of modules was restructured to accommodate the shape of the AA. For example, a $10 \mathrm{~m}$ x $50 \mathrm{~m}$ plot was used for narrow, linear areas and a $20 \mathrm{~m}$ x $20 \mathrm{~m}$ plot was used for small, circular sites.

- The plot captured the range of diversity within the AA, without crossing over into the upland. No more than $20 \%$ of the plot was located in upland areas beyond the wetland. If end modules crossed into the upland, they were not sampled as intensive modules.

- If a small patch of another wetland type was present in the AA (but not large enough to be delineated as a separate Ecological System), the plot was placed so at least a portion of the patch was in the plot.

- Localized, small areas of human-induced disturbance were included in the plot according to their relative representation of the AA.

Absolute cover of all vascular species was estimated within four of the $100 \mathrm{~m}^{2}$ modules, referred to as intensive modules. When all species within a module had been identified, cover was visually estimated for the $100 \mathrm{~m}^{2}$ module using the following cover classes (Peet et al. 1998): 
Class $1=$ trace (one individual or two individuals)

Class $2<1 \%$

Class $3 \geq 1-2 \%$

Class $4 \geq 2-5 \%$

Class $5 \geq 5-10 \%$
Class $6 \geq 10-25 \%$

Class $7 \geq 25-50 \%$

Class $8 \geq 50-75 \%$

Class $9 \geq 75-95 \%$

Class $10 \geq 95 \%$

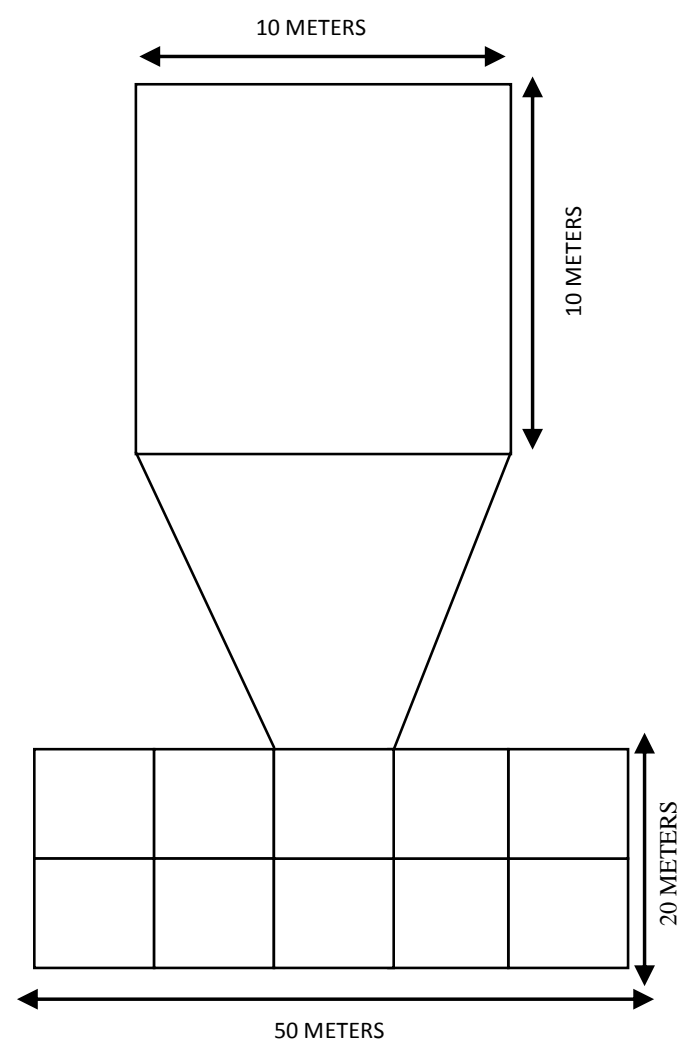

Figure 7. Reléve plot layout (adapted from Peet et al. 1998).

After sampling each of the intensive modules, the remaining, or residual, modules were walked to document presence of any species not recorded in the intensive modules. Percent cover of these species was estimated over the entire $1,000 \mathrm{~m}^{2}$ plot.

In the field, vascular plants were identified using the Manual of Montana Vascular Plants (Lesica 2012) as well as ancillary dichotomous keys specific to certain plant genera (e.g., carices). The state-based nomenclature was crosswalked to nationally accepted nomenclature based on the USDA PLANTS Database (http://plants.usda.gov).

3.4.5 Intensive Assessment of Stressors: To capture the actual spatial extent of stressors observed within the 200-m envelope around the AA perimeter, we estimated the percent of the 200-m envelope affected by each stressor. For linear features such as roads, we estimated the length in meters of each stressor within the 200-m envelope. 


\subsection{Data Management}

We created a relational database in Microsoft Access ${ }^{\circledR}$. All EIA data and vegetation plot data were entered into the database after field data collection was complete. For vegetation data, plant species mean cover values were averaged across modules to get an average cover value for each plant species for the entire vegetation plot. Unknown species or ambiguous species (e.g., Carex sp.) were entered into the database, but these were not included in data analysis.

\subsection{Data Analysis}

3.6.1 Level 2 Assessments: Scores were calculated for each randomly selected site using metric narrative ratings and scoring formulas (Appendix E). A score was calculated for the site overall as well as separately for each major attribute.

We calculated descriptive statistics for and assessed the range and distribution of each metric by examining frequency histograms. We created correlation matrices using Spearman's correlation coefficients to investigate relationships and to evaluate any redundancy among metrics.

Similarly, we calculated Spearman's correlation coefficients of attribute scores and final wetland condition scores to determine the amount of variability explained by each attribute and each metric.

3.6.2 Level 3 Vegetation Assessments: For the randomly selected sites $(n=24)$, we calculated multiple vegetation metrics (Appendix F) to conduct a floristic quality assessment (FQA). The FQA accounts for the presence of both native and exotic species, as well as individual plant species' tolerance of disturbance (Cronk and Fennessy 2001, Miller and Wardrop 2006). Coefficients of conservatism (C-values) are assigned to taxa identified to species and represent the relative tolerance of a species to disturbance, ranging from 0 to 10 (after Andreas et al. 2004). Native species that exhibit high degrees of ecological specificity and sensitivity to disturbance have $\mathrm{C}$-values of 9-10. Native species that are typical of well-established communities that have undergone minimal disturbance have C-values of 6-8. Native species that have some degree of habitat specificity but can tolerate moderate disturbance have C-values of 3-5. Widespread native species that occur in a variety of communities and are common in disturbed sites have values of 1-2. Finally, exotic species were assigned $\mathrm{C}$-values of 0 . C-values were recently assigned to most Montana wetland species by the Montana Natural Heritage Program (MTNHP 2015); these values were used in calculation of metrics.

We also calculated a wetland index that is based upon species' wetland indicator status from the National Wetland Plant List (Lichvar et al 2014). Each wetland indicator status category was assigned a value from +2 (UPL) to -2 (OBL), representing a coefficient of wetness for each taxa identified to species. These coefficients of wetness are averaged and the mean is considered a wetness index. A wetness index of zero or less indicates a predominance of wetland species. Only native species are considered in this calculation, as exotic species tend to skew the distribution of wetland indicators towards upland categories (Herman et al. 1997).

We calculated descriptive statistics for and assessed the range and distribution of vegetation metrics by examining frequency histograms. We created correlation matrices using Spearman's 
correlation coefficients to investigate relationships and to evaluate any redundancy among metrics. We also used Spearman's correlation coefficients to evaluate the relationship of metrics to observed stressors as well as the ability of metrics to discriminate among wetland sites of varying condition.

3.6.3 Ecological System Descriptions. We reviewed academic and agency publications, as well as MTNHP records. We calculated descriptive statistics on plant species frequency across the sites as a whole and in relation to the different water regimes found in these ecological systems, using the Level 3 field assessment data from 31 sites. We identified apparent plant associations, and reviewed these against known associations in the MTNHP Ecological Community Lists (MTNHP 2002) and in the Draft National Vegetation Classification Standard (NatureServe in preparation). Following the format of our Montana Field Guide for Ecological Systems, we created a draft description of the Intermontane Prairie Pothole Ecological System.

3.6.4 Does water regime influence Floristic Quality Index scores? To ensure a sufficient sample, we combined the data from the randomly selected Level 3 sites in this project with Level 3 data from earlier studies to evaluate whether relative wetness is a predictive factor influencing the outcome of Floristic Quality Assessment (FQA) scoring. We began by calculating mean values of Coefficients of Conservatism (C-values) for 1,409 wetland plant species found in Montana, grouped according to their Wetland Indicator Status (WIS) assigned by Lichvar et al. (2014). Because Montana wetland plant species occur in two ACOE regions, we calculated these values separately for each region. Next, for each Level 3 assessment site included in the analysis, we examined the percentage of plant species that fell into either the Obligate Wetland Species (OBLW) or Facultative Wetland Species (FACW), using an Access query. FQAI scores and percentage of WIS scores were exported into R for further analysis. We used Spearman's correlation to identify the relationship between the percentage of wetland species and each FQA score. We also used descriptive statistics to summarize mean FQA scores and mean percentage of WIS by water permanence, based on field observations reported from each site.

\subsection{RESULTS}

\subsection{Wetland Landscape Profile}

Based on digital mapping, wetlands and other water bodies within the study area totaled 97,847 acres (39,597 hectares). These totals include deepwater areas such as lakes and river channels, which provide critical aquatic habitat and other valuable ecosystem services but are not considered wetlands. By system, the majority (76\%) of the mapped acres are palustrine wetlands (Figure 8). By class, freshwater emergent wetlands make up the largest proportion (41\%) of wetland acres (Figure 9). By water regime, temporarily and seasonally flooded wetlands are the most common (Figure 10). These wetlands typically have surface water for a few days or weeks during the growing season but dry down later in the season. 


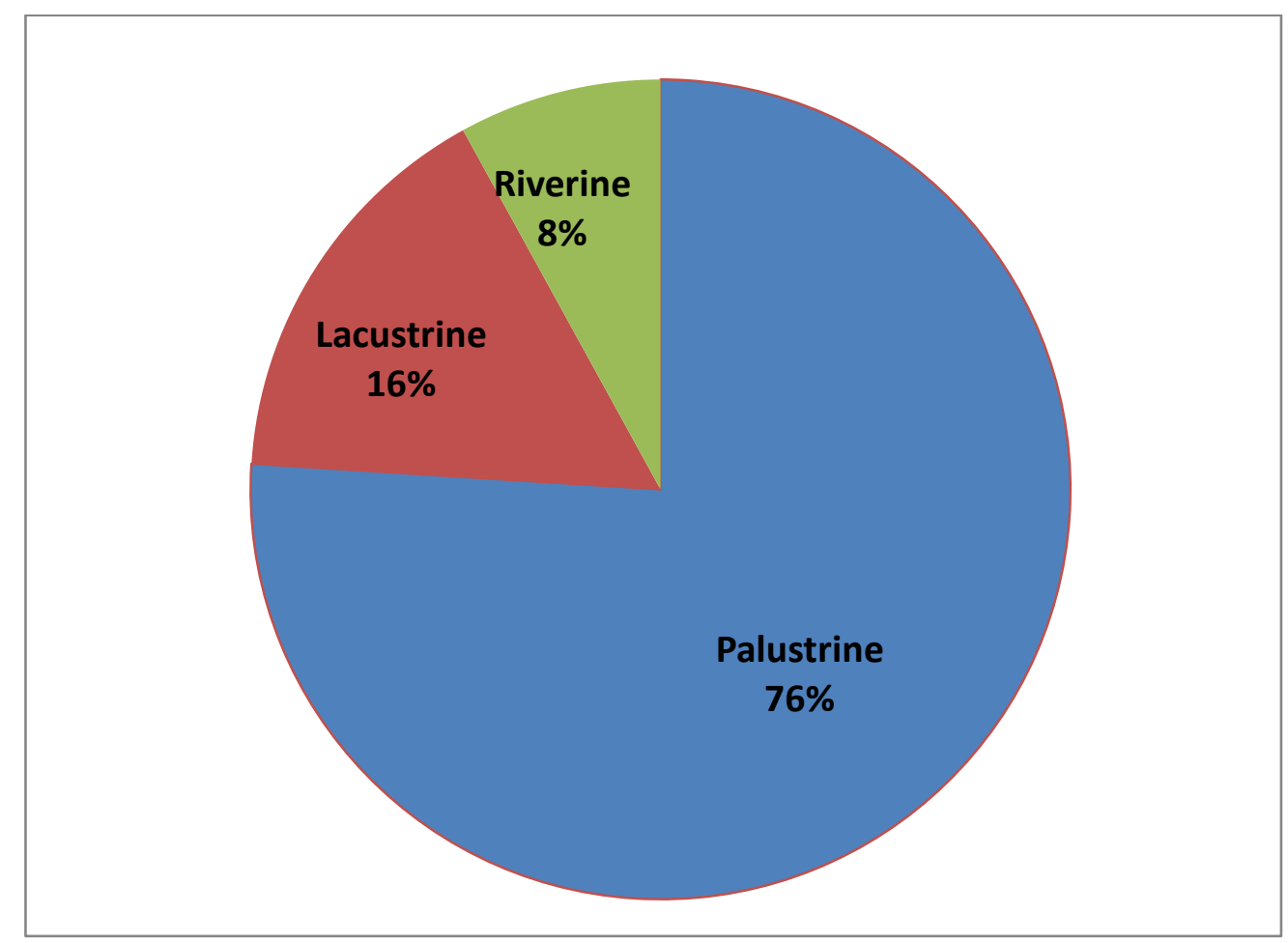

Figure 8. Percent of mapped wetland acres by Cowardin system in the Blackfoot-Swan Intensification Project area.

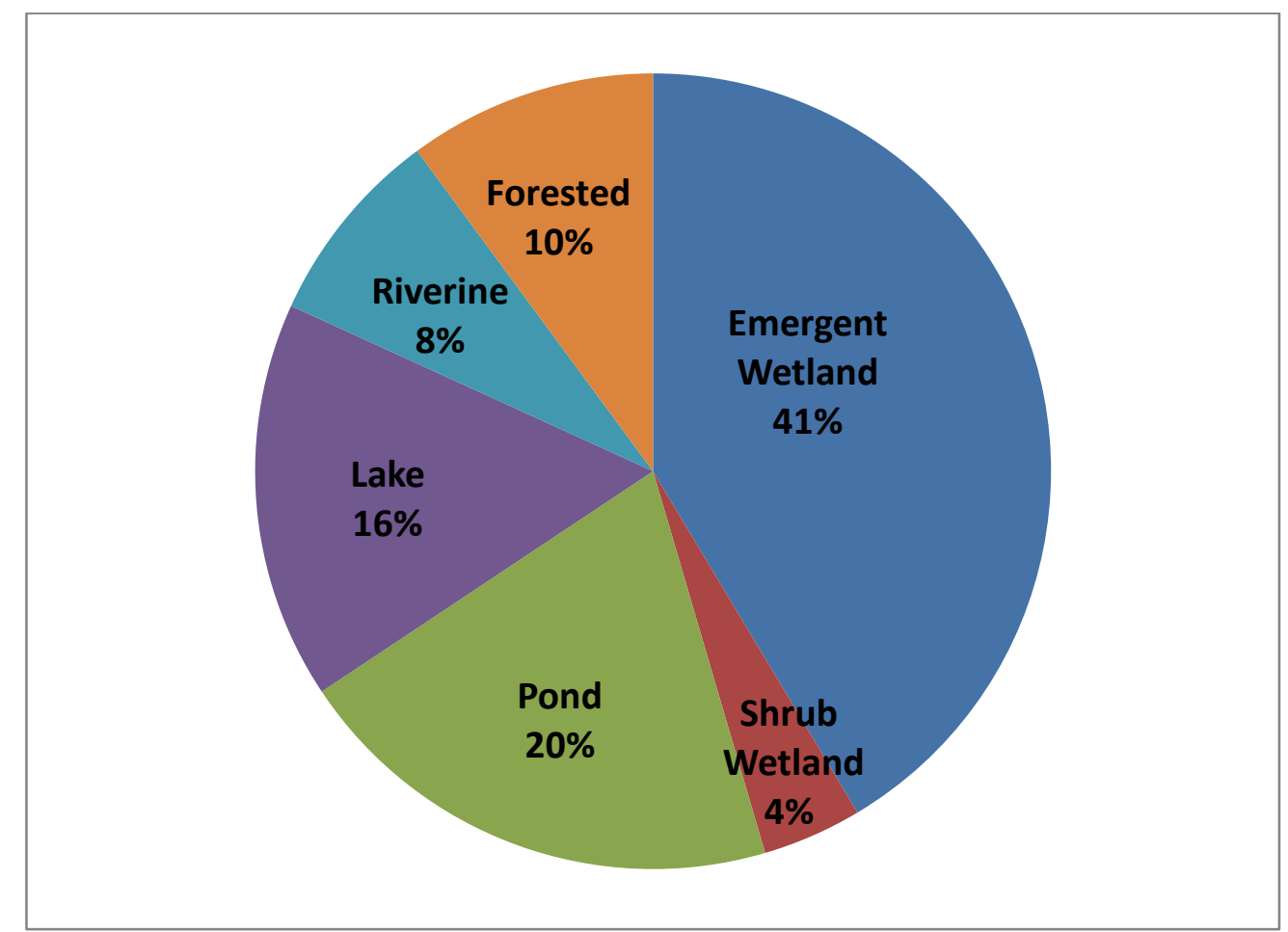

Figure 9. Percent of mapped wetland acres by Cowardin class in the Blackfoot-Swan Intensification Project area. 


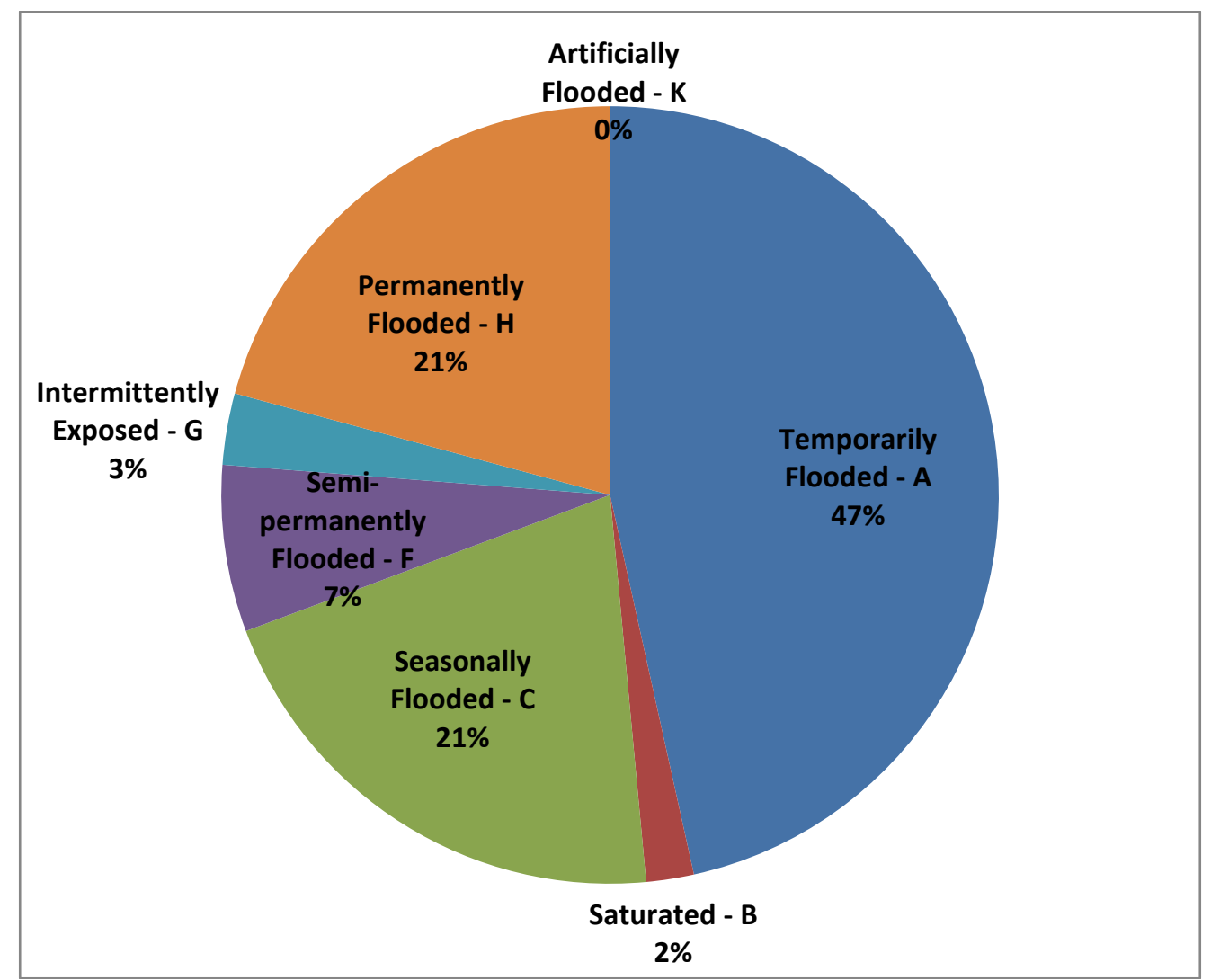

Figure 10. Percent of mapped wetland acres by Cowardin water regime in the Blackfoot-Swan Intensification Project area.

Most anthropogenically altered wetlands in the project area fell into the Palustrine System, as these mapped wetland types represent reservoirs created by stream impoundments or excavated wetlands (Figure 11). Altered lacustrine wetlands represent large reservoirs created by stream impoundments. The spatial distribution of palustrine wetlands by watershed is included in Appendix G.

\subsection{Level 1 Landscape Characterization}

Mean human disturbance index (HDI) scores (Figure 12) were relatively consistent across all three envelopes (100 m, $300 \mathrm{~m}$, and $1000 \mathrm{~m}$ ) for wetland types in the Blackfoot and Swan subbasins (Table 6), suggesting moderate levels of disturbance.

We calculated human disturbance index (HDI) scores separately for surveyed and non-surveyed wetlands. Although we used a GRTS approach to select candidate wetlands from all ownership classes for our surveys, the candidates were further screened for accessibility. Therefore, surveyed wetlands were more likely to be near roads than were randomly chosen wetlands. Similarly, although our randomly selected wetlands included both privately owned wetlands and 


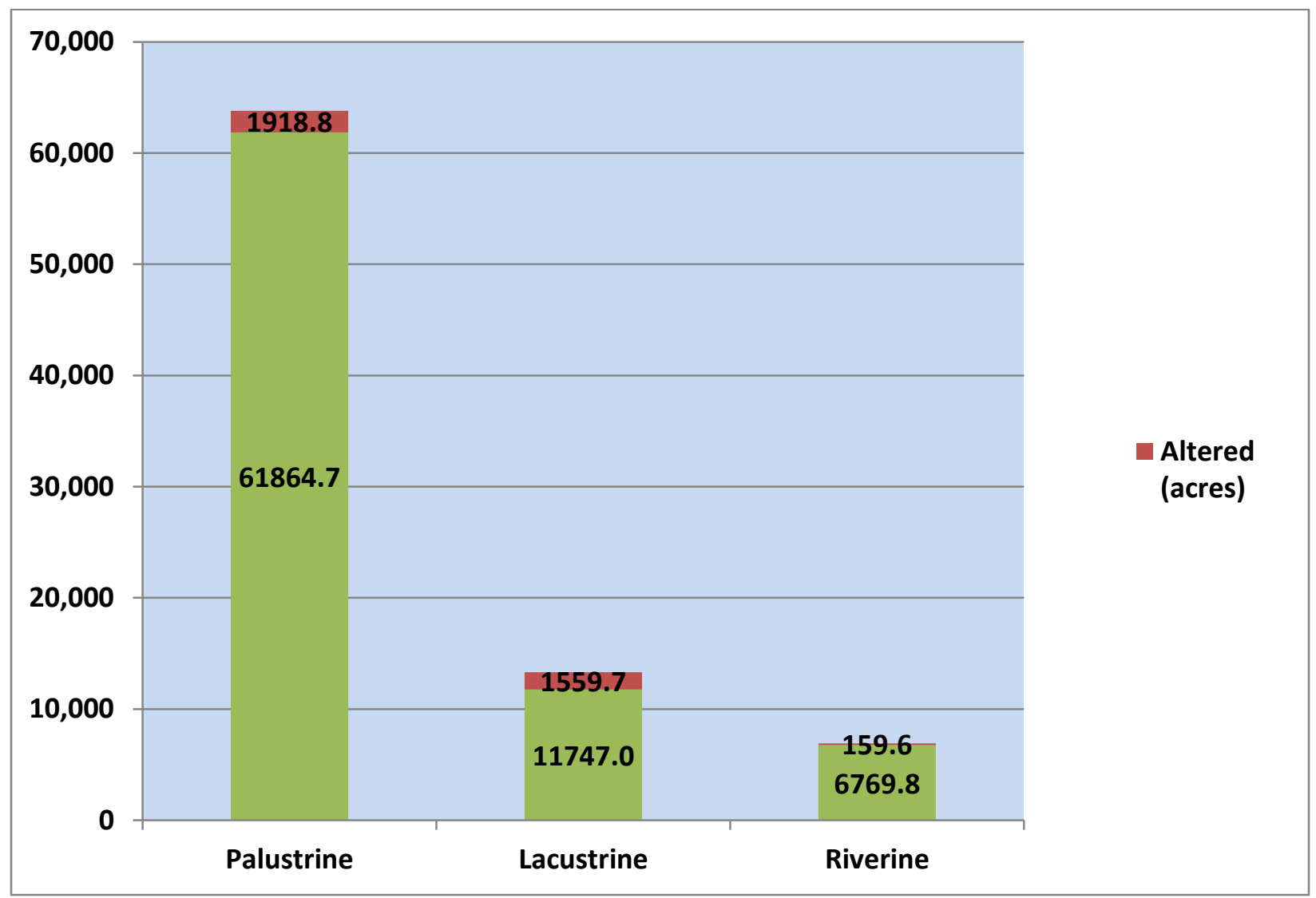

Figure 11. Proportion of mapped wetlands classified as anthropogenically altered by Cowardin system in the Blackfoot-Swan Intensification Project area.

wetlands on public land, we were frequently denied access by landowners. As a result, surveyed wetlands were disproportionately on public land. Because these two populations of wetlands randomly chosen, and randomly chosen then screened-differed in these two ways, we hypothesized that there would be differences in the HDI scores. This proved to be the case. For wetlands which were randomly selected (and not surveyed in the field) for Level 1 landscape characterization, mean HDI scores were lower for public lands than they were for private lands (Table 7; $\mathrm{P}<0.001$ in all instances), indicating fewer disturbances on public lands. In contrast, for those wetlands surveyed for Level 2 assessment, no statistically significant differences were found between HDI scores for public versus private lands (Table 7). Across all wetland sites, mean HDI scores were lower for Level 2 sites than they were for randomly selected sites; these differences were significant at $100 \mathrm{~m}$ and $300 \mathrm{~m}$, but not at $1000 \mathrm{~m}$ (Table 8). Again, we surmise that this reflects a public land effect. 


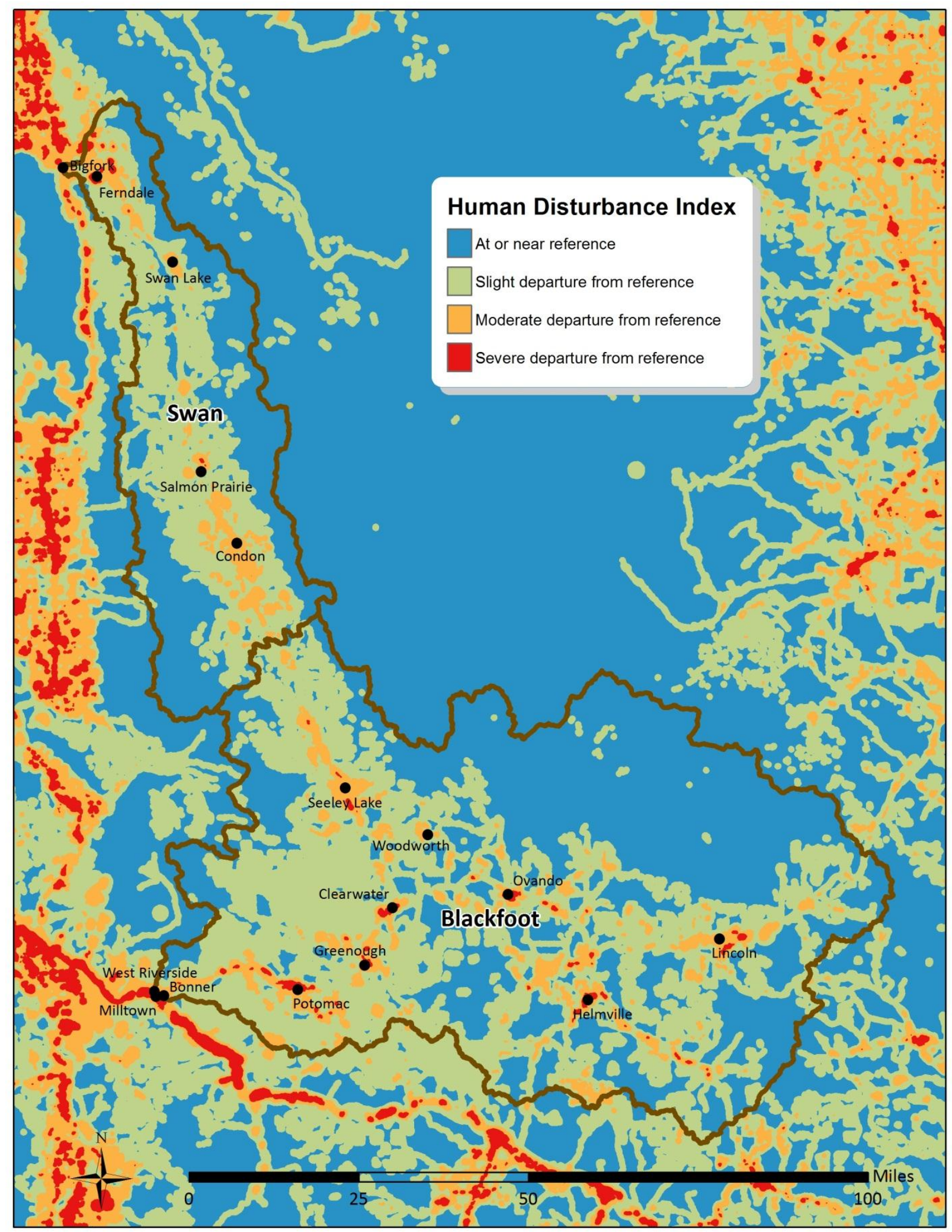

Figure 12. Human disturbance index for the Blackfoot-Swan Intensification Project and surrounding areas. 
Table 6. Mean, standard deviation (SD), minimum, and maximum values for mean human disturbance index (HDI) by wetland type within $100 \mathrm{~m}$, $300 \mathrm{~m}$, and 1,000 m envelopes around Level 2 surveyed wetlands $(n=119)$ and randomly selected wetlands $(n=881)$ in the Blackfoot and Swan subbasins.

Results are also presented for 7 sites surveyed to help characterize the Intermontane Potholes ecological system) at Ninepipe National Wildlife Refuge in the Lower Flathead subbasin. Note: all wetland types are freshwater, e.g., Freshwater Emergent.

\begin{tabular}{|c|c|c|c|c|c|c|c|c|c|c|c|c|c|}
\hline & \multicolumn{13}{|c|}{ Human Disturbance Index } \\
\hline \multicolumn{14}{|l|}{$\begin{array}{l}\text { Blackfoot } \\
\text { Level } 2\end{array}$} \\
\hline Emergent & 44 & 323.60 & 342.75 & 0 & 1523.07 & 340.45 & 337.27 & 0 & 1492.97 & 409.84 & 312.46 & 0 & 1292.86 \\
\hline Forested/Shrub & 8 & 452.53 & 207.44 & 108.92 & 711.08 & 448.56 & 184.52 & 170.78 & 682.82 & 421.62 & 148.22 & 152.52 & 609.21 \\
\hline Pond & 14 & 282.49 & 395.82 & 0.02 & 1471.02 & 293.38 & 387.68 & 0.31 & 1459.44 & 379.26 & 325.33 & 33.11 & 1228.51 \\
\hline \multicolumn{14}{|l|}{ Random } \\
\hline Forested & 22 & 478.96 & 501.89 & 0 & 1621.73 & 475.50 & 502.71 & 0 & 1685.46 & 442.95 & 458.89 & 0 & 1688.19 \\
\hline Pond & 13 & 632.68 & 469.95 & 0 & 1340.20 & 629.92 & 476.17 & 0.06 & 1377.47 & 595.88 & 458.59 & 25.41 & 1550.21 \\
\hline Scrub-shrub & 154 & 609.42 & 456.08 & 0 & 1918.62 & 605.03 & 441.41 & 0 & 1855.86 & 565.14 & 369.21 & 0 & 1690.39 \\
\hline \multicolumn{14}{|l|}{ Swan } \\
\hline \multicolumn{14}{|l|}{ Random } \\
\hline Emergent & 220 & 412.46 & 462.49 & 0 & 1609.01 & 415.09 & 460.88 & 0 & 1588.45 & 424.71 & 449.80 & 0 & 1574.07 \\
\hline Forested & 33 & 237.11 & 363.51 & 0 & 1342.49 & 241.97 & 367.34 & 0 & 1299.48 & 253.45 & 344.71 & 0 & 1149.58 \\
\hline Pond & 58 & 367.85 & 480.23 & 0 & 2268.13 & 365.77 & 468.90 & 0 & 2199.92 & 358.12 & 406.26 & 0 & 1705.74 \\
\hline Scrub-shrub & 136 & 306.42 & 415.33 & 0 & 1824.21 & 308.19 & 409.21 & 0 & 1775.82 & 322.73 & 390.17 & 0 & 1534.37 \\
\hline \multicolumn{14}{|l|}{ Ninepipe } \\
\hline Emergent & 6 & 623.71 & 381.92 & 287.87 & 1179.59 & 636.39 & 390.58 & 284.28 & 1202.34 & 745.77 & 303.22 & 401.44 & 1139.31 \\
\hline Pond & 1 & 1004.65 & 0 & -- & -- & 970.25 & 0 & -- & -- & 969.57 & 0 & -- & -- \\
\hline
\end{tabular}


Table 7. Comparison of mean human disturbance index (HDI) values within $100 \mathrm{~m}, 300 \mathrm{~m}$, and $1000 \mathrm{~m}$ envelopes around wetland sites under public and private ownership in the Blackfoot and Swan subbasins.

\begin{tabular}{|c|c|c|c|c|c|c|c|c|c|c|c|c|c|c|c|c|}
\hline \multirow[b]{3}{*}{ Envelope } & \multicolumn{8}{|c|}{ Level 2 Surveyed Sites } & \multicolumn{8}{|c|}{ Randomly Selected Sites } \\
\hline & \multicolumn{3}{|c|}{ Public } & \multicolumn{3}{|c|}{ Private } & \multirow[b]{2}{*}{$t$-test } & \multirow[b]{2}{*}{$P$} & \multicolumn{4}{|c|}{ Public } & \multicolumn{2}{|c|}{ Private } & \multirow[b]{2}{*}{$t$-test } & \multirow[b]{2}{*}{$P$} \\
\hline & $n$ & mean & $s d^{*}$ & $n$ & mean & $s d$ & & & $n$ & mean & $s d$ & $n$ & mean & $s d$ & & \\
\hline Blackfoot & 63 & & & 3 & & & & & 208 & & & 226 & & & & \\
\hline $100 \mathrm{~m}$ & & 333.86 & 346.57 & & 260.10 & 200.71 & 0.5956 & 0.593 & & 373.17 & 365.75 & & 781.65 & 540.82 & 9.2803 & $<0.001$ \\
\hline $300 \mathrm{~m}$ & & 347.49 & 338.99 & & 261.19 & 174.78 & 0.7876 & 0.488 & & 373.09 & 354.72 & & 774.10 & 523.07 & 9.4113 & $<0.001$ \\
\hline $1000 \mathrm{~m}$ & & 409.39 & 302.81 & & 307.94 & 113.80 & 1.3354 & 0.253 & & 375.72 & 309.83 & & 713.11 & 430.46 & 9.4251 & $<0.001$ \\
\hline Swan & 49 & & & 4 & & & & & 342 & & & 105 & & & & \\
\hline $100 \mathrm{~m}$ & & 423.03 & 406.32 & & 832.60 & 398.17 & -1.9751 & 0.120 & & 213.29 & 321.91 & & 844.07 & 456.81 & 13.1802 & $<0.001$ \\
\hline $300 \mathrm{~m}$ & & 426.66 & 389.38 & & 822.04 & 402.95 & -1.8916 & 0.155 & & 214.14 & 318.39 & & 849.50 & 443.61 & 13.6373 & $<0.001$ \\
\hline $1000 \mathrm{~m}$ & & 428.50 & 319.41 & & 790.08 & 434.69 & -1.6281 & 0.202 & & 220.46 & 304.94 & & 867.26 & 369.12 & 16.3263 & $<0.001$ \\
\hline
\end{tabular}

$*_{\mathrm{sd}}=$ standard deviation; $\mathrm{t}$-test $=\mathrm{t}$ statistic from two-sample $\mathrm{t}$-test assuming unequal variances; $\mathrm{P}$ is two-tailed.

Table 8. Comparison of mean human disturbance index (HDI) values for $100 \mathrm{~m}, 300 \mathrm{~m}$, and $1000 \mathrm{~m}$ envelopes around Level 2 surveyed sites and randomly selected sites.

\begin{tabular}{lcccccc}
\hline \multicolumn{2}{c}{$\begin{array}{c}\text { Level 2 Surveyed Sites } \\
(\boldsymbol{n}=\mathbf{1 1 9})\end{array}$} & \multicolumn{2}{c}{ Randomly Selected } \\
Envelope & mean & Sites $(\boldsymbol{n}=\mathbf{8 8 1})$ & mean & sd & t-test & P, two-tail \\
\hline & & & & & & \\
$100 \mathrm{~m}$ & 385.48 & 379.69 & 472.02 & 490.44 & 2.246037467 & 0.025945272 \\
$300 \mathrm{~m}$ & 393.87 & 367.37 & 471.04 & 480.30 & 2.065499298 & 0.040324933 \\
$1000 \mathrm{~m}$ & 427.50 & 315.75 & 460.59 & 426.98 & 1.023706089 & 0.307332861 \\
\hline
\end{tabular}




\subsection{Level 2 Assessments}

We visited 126 sites during the summers of 2013 and 2014: 66 in the Blackfoot, 53 in the Swan, and 7 at Ninepipe National Wildlife Refuge in the Lower Flathead subbasin (Figure 13). The Ninepipe sites, as well as 19 sites in the Blackfoot drainage, were part of a target sampling effort to aid in the characterization of the newly-defined Intermontane Potholes ecological system.

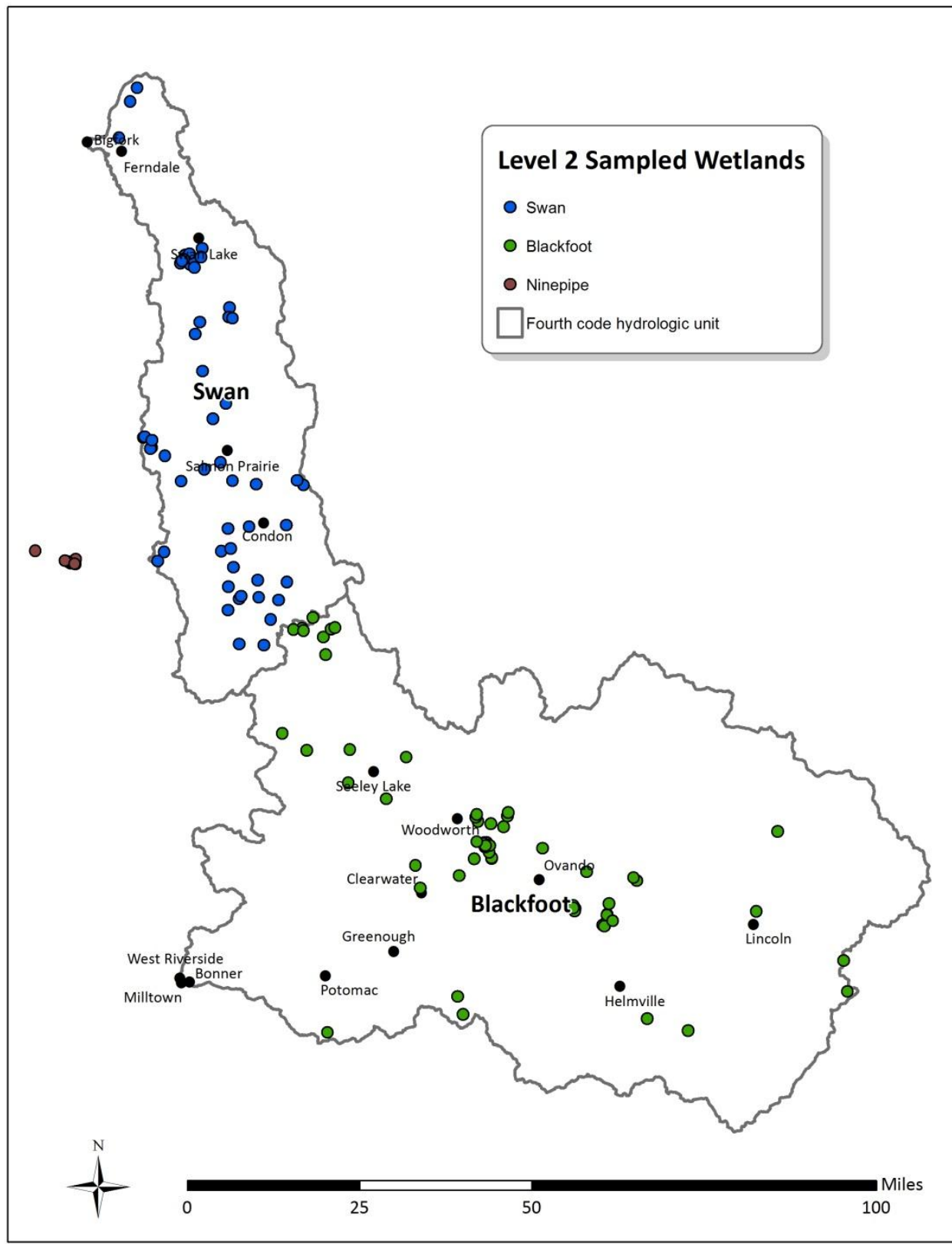

Figure 13. 126 wetland sites that were sampled for Level 2 assessment in the Blackfoot-Swan Intensification Project area. 
Sixty-one percent of the sampled sites are on federal lands, with the remainder held by the state of Montana (33\%) or under private ownership (6\%) (Figure 14).

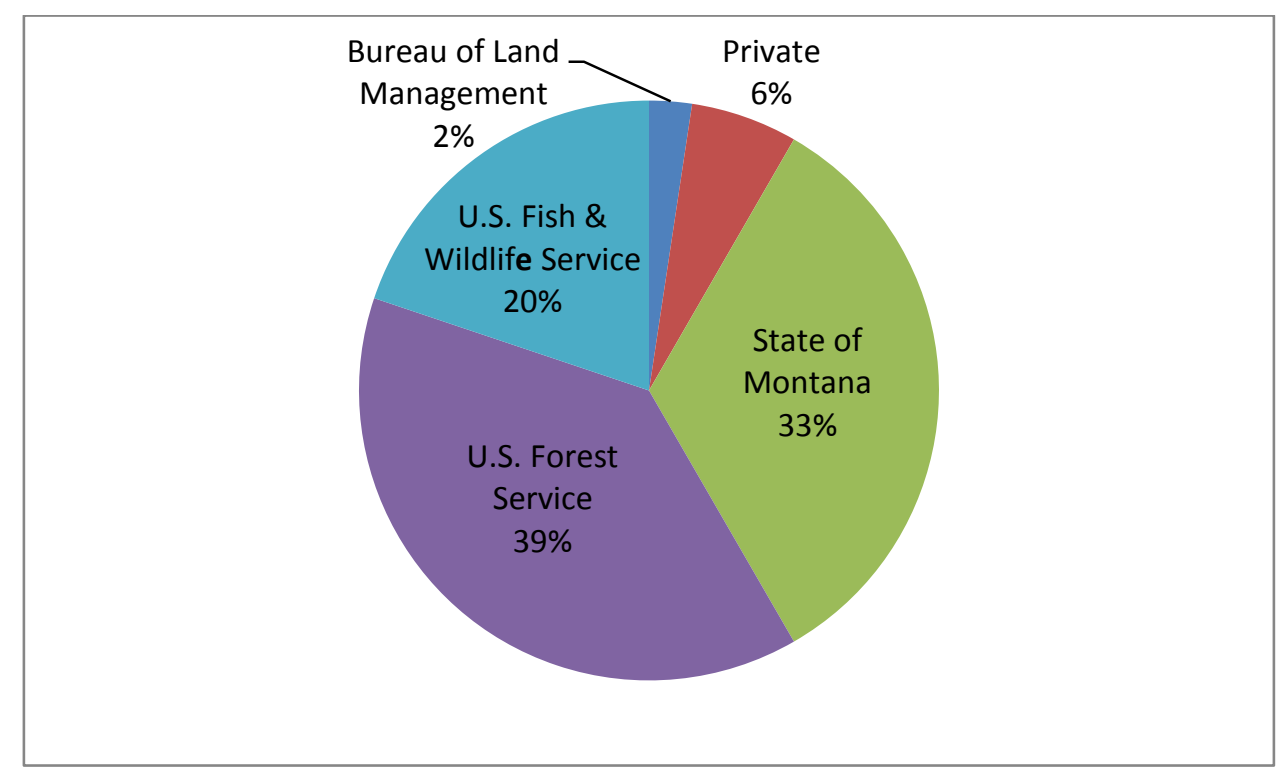

Figure 14. Sampled wetlands by land ownership in the Blackfoot-Swan Intensification Project area.

Sampled wetlands represented nine ecological systems (Table 9). Intermontane Potholes were the most commonly sampled type, followed by Rocky Mountain Subalpine-Montane Fens and Rocky Mountain Alpine-Montane Wet Meadows. Together, these three ecological systems represented $68 \%$ of the sites. Representative photos are included below (Figures 15-23).

Table 9. Sampled wetlands by Ecological System in the Blackfoot-Swan Intensification Project area.

Number of

Ecological System Sites Surveyed

Intermontane Pothole 37

Northern Rocky Mountain Lower Montane Riparian Woodland and Shrubland

Northern Rocky Mountain Conifer Swamp

Northern Rocky Mountain Wooded Vernal Pool

Rocky Mountain Alpine-Montane Wet Meadow

Rocky Mountain Subalpine-Montane Fen

Rocky Mountain Subalpine-Montane Riparian Shrubland

Rocky Mountain Subalpine-Montane Riparian Woodland

Western North American Emergent Marsh 


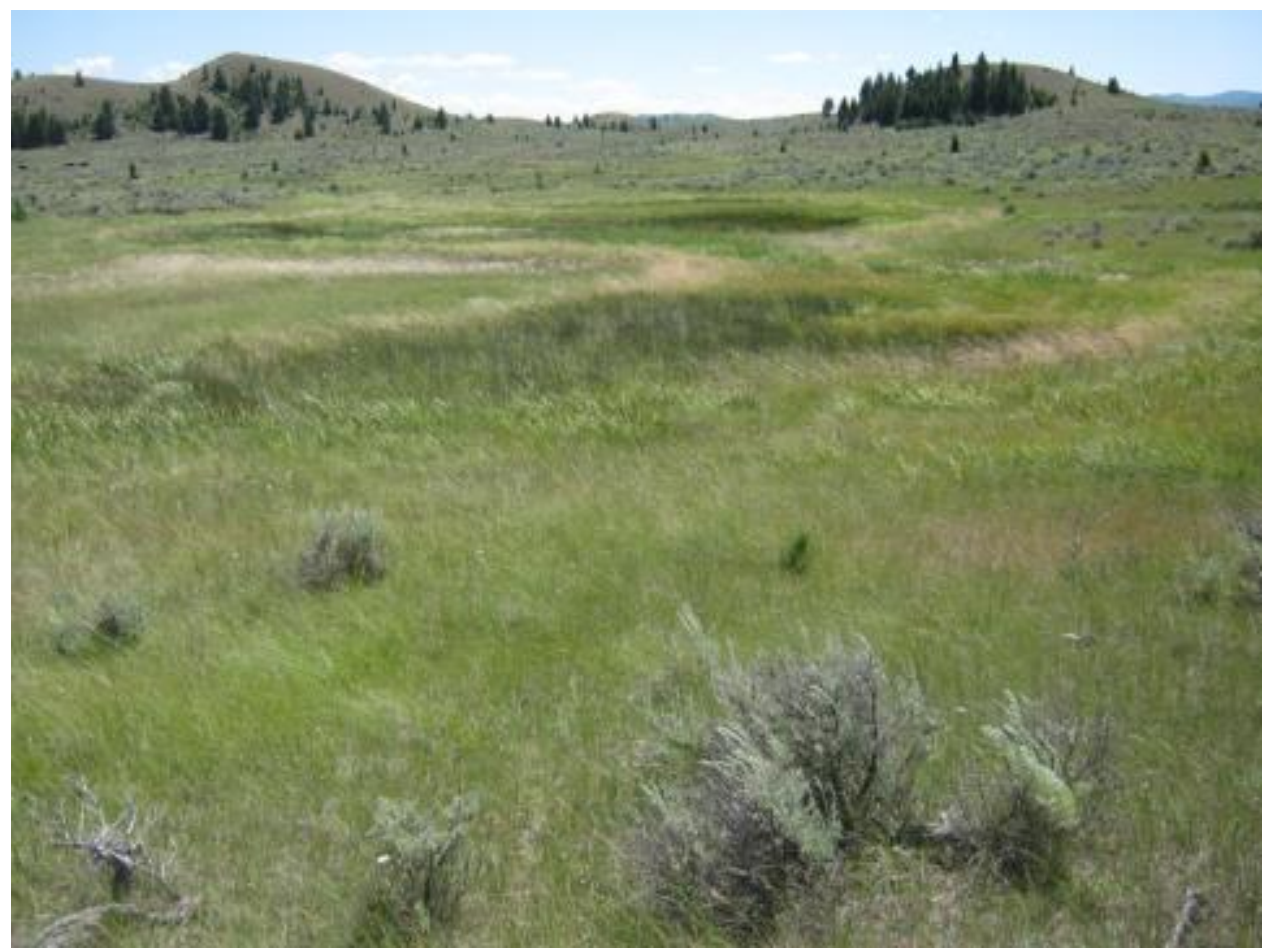

Figure 15. An Intermontane Prairie Pothole sampled as part of the Blackfoot-Swan Intensification Project.

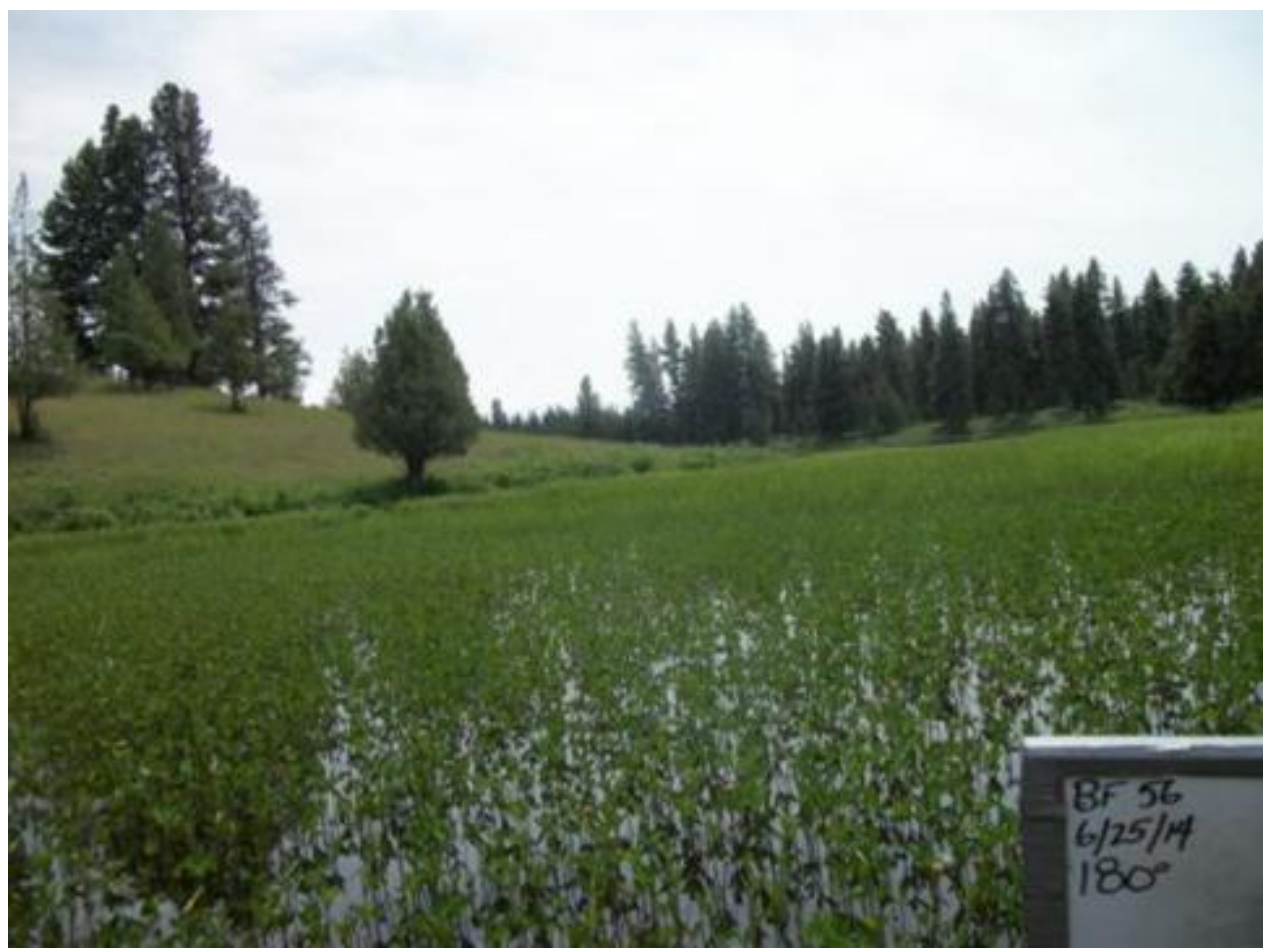

Figure 16. A Western North American Emergent Marsh sampled as part of the Blackfoot-Swan Intensification Project. 


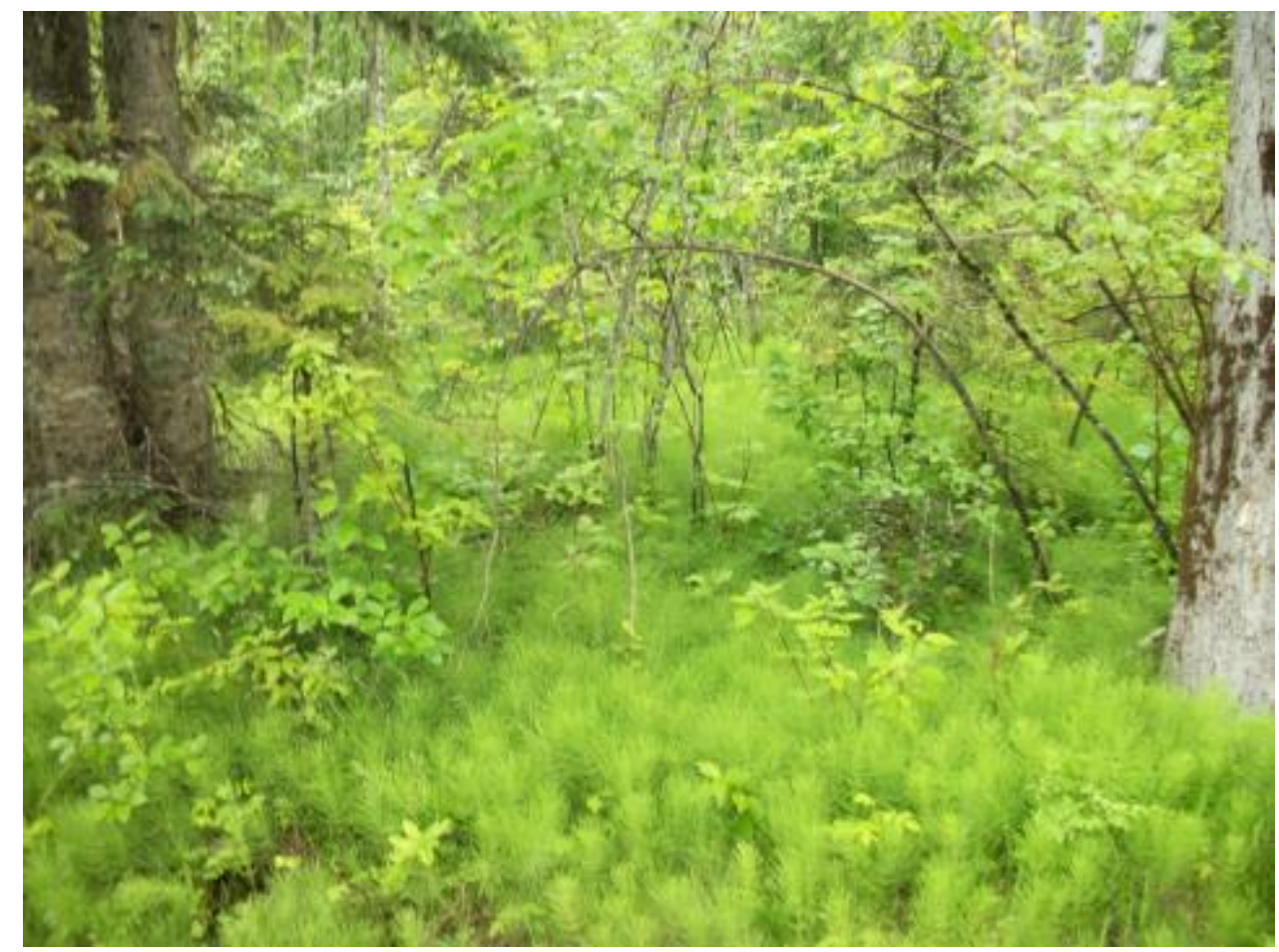

Figure 17. A Northern Rocky Mountain Lower Montane Riparian Woodland and Shrubland sampled as part of the Blackfoot-Swan Intensification project.

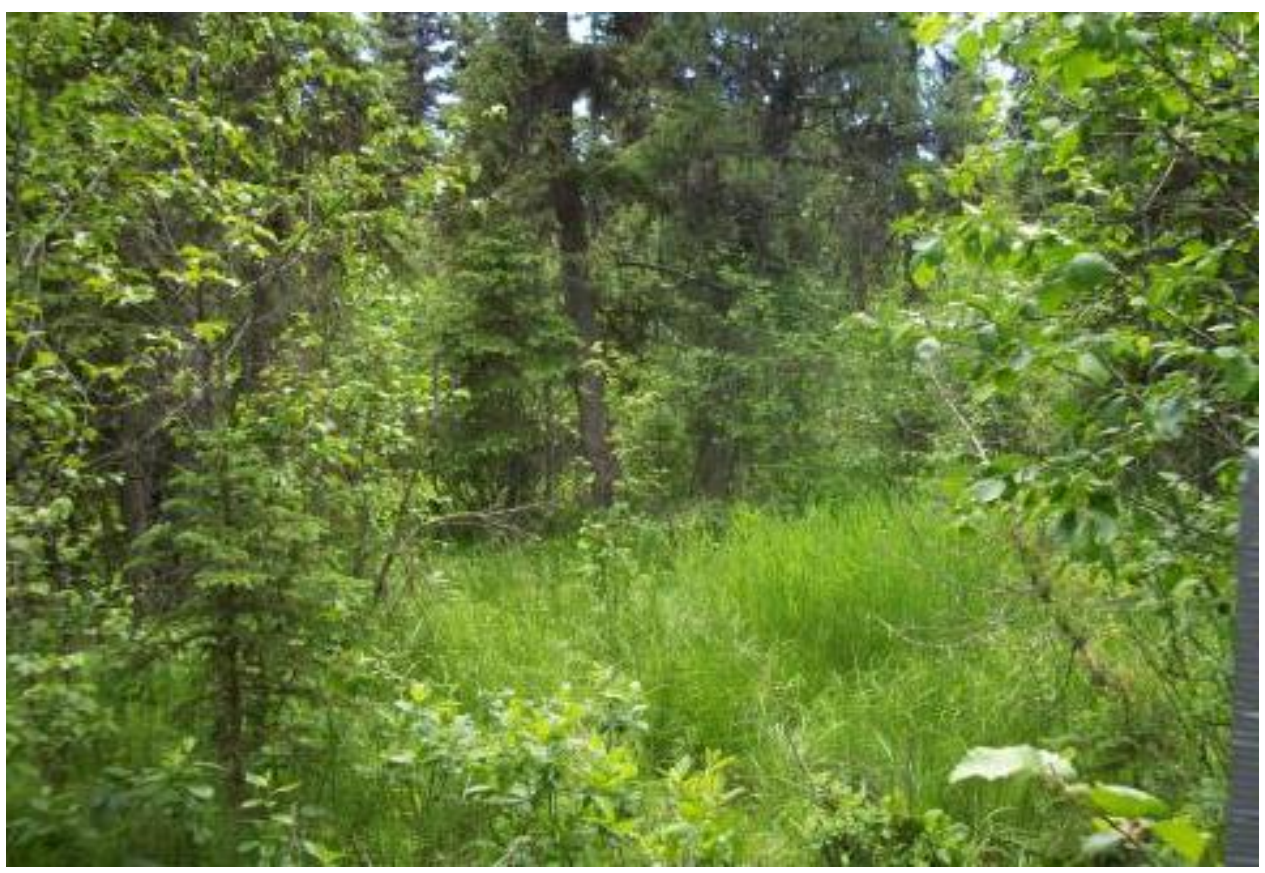

Figure 18. A Northern Rocky Mountain Conifer Swamp sampled as part of the Blackfoot-Swan Intensification project. 


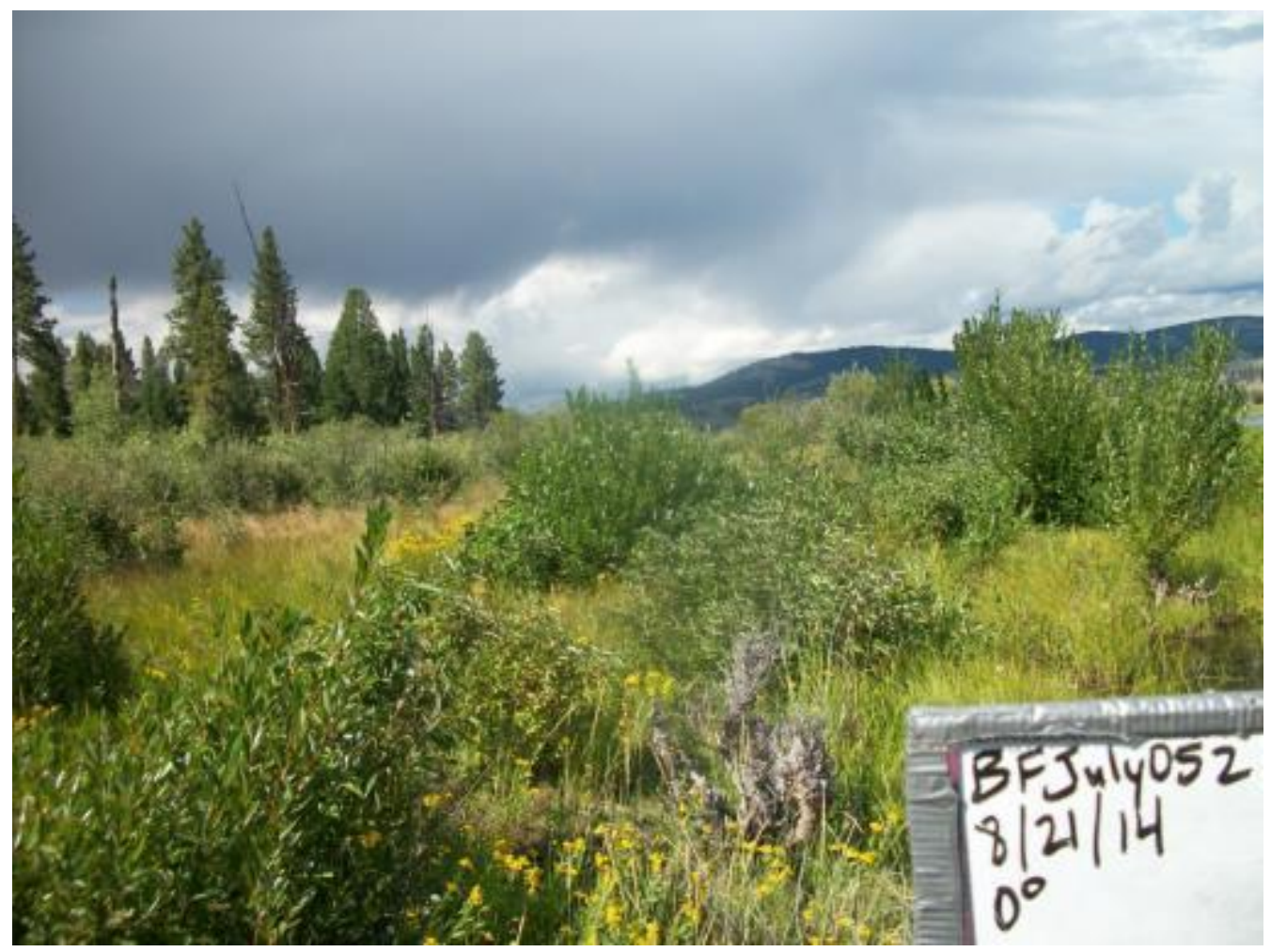

Figure 19. A Rocky Mountain Subalpine Shrubland sampled as part of the Blackfoot-Swan Intensification project.

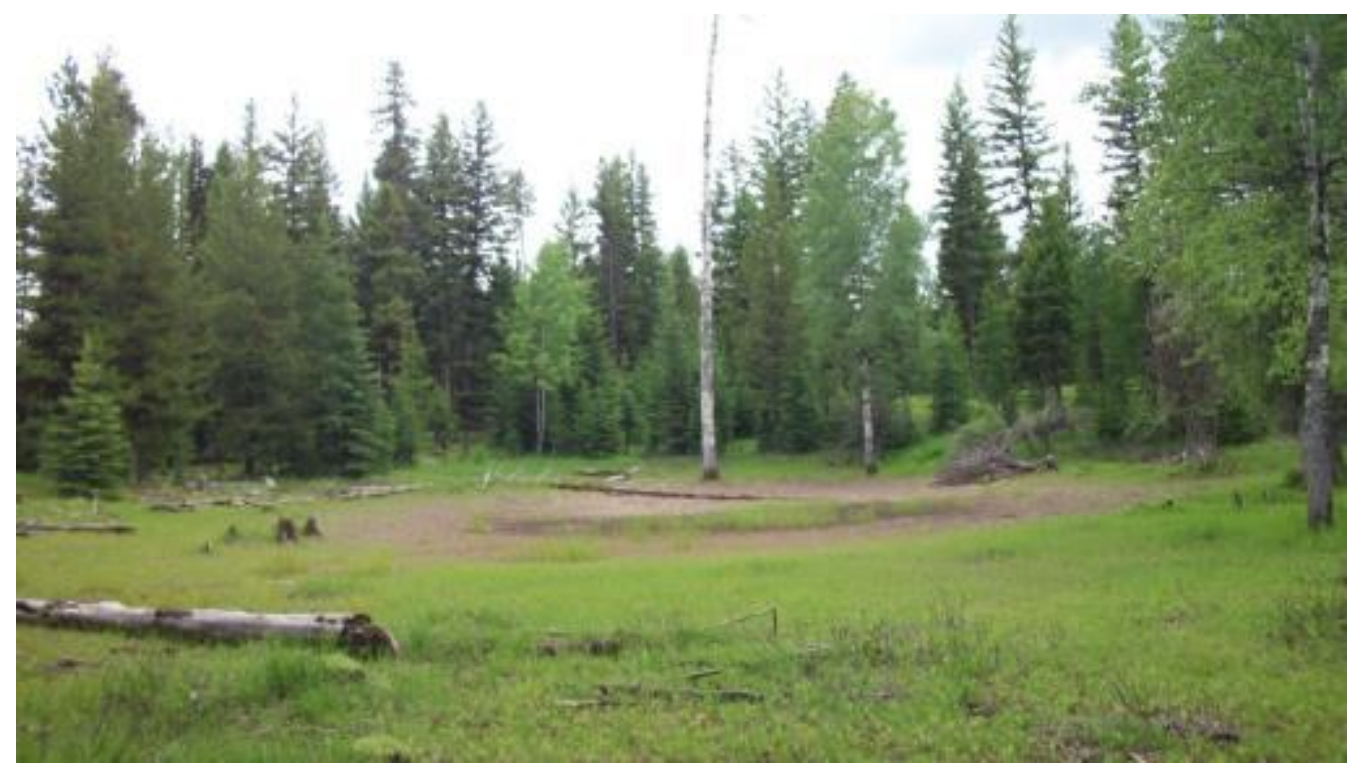

Figure 20. A Northern Rocky Mountain Wooded Vernal Pool sampled as part of the Blackfoot-Swan Intensification project. 


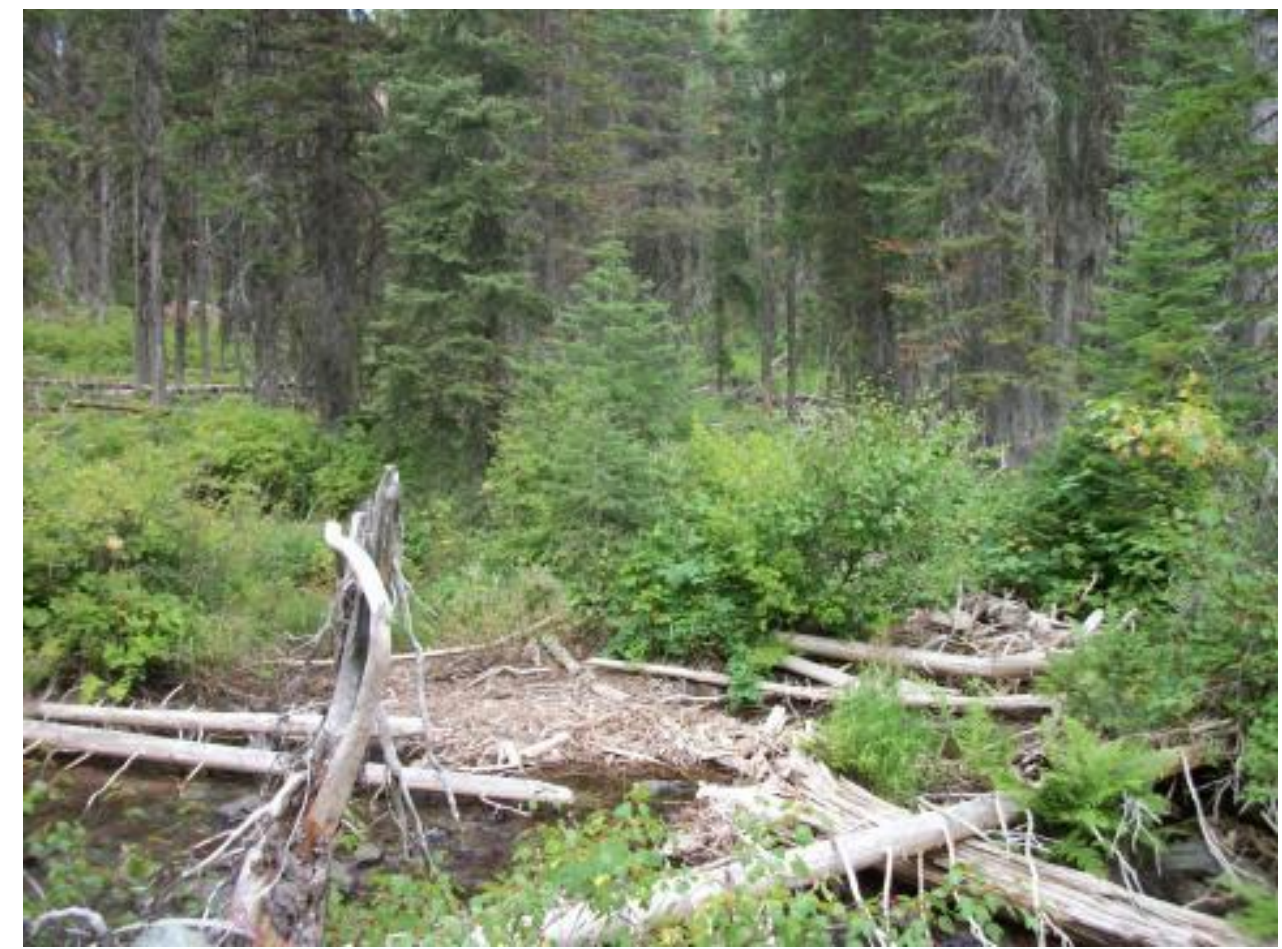

Figure 21. A Northern Rocky Mountain Subalpine-Montane Riparian

Woodland sampled as part of the Blackfoot-Swan Intensification project.

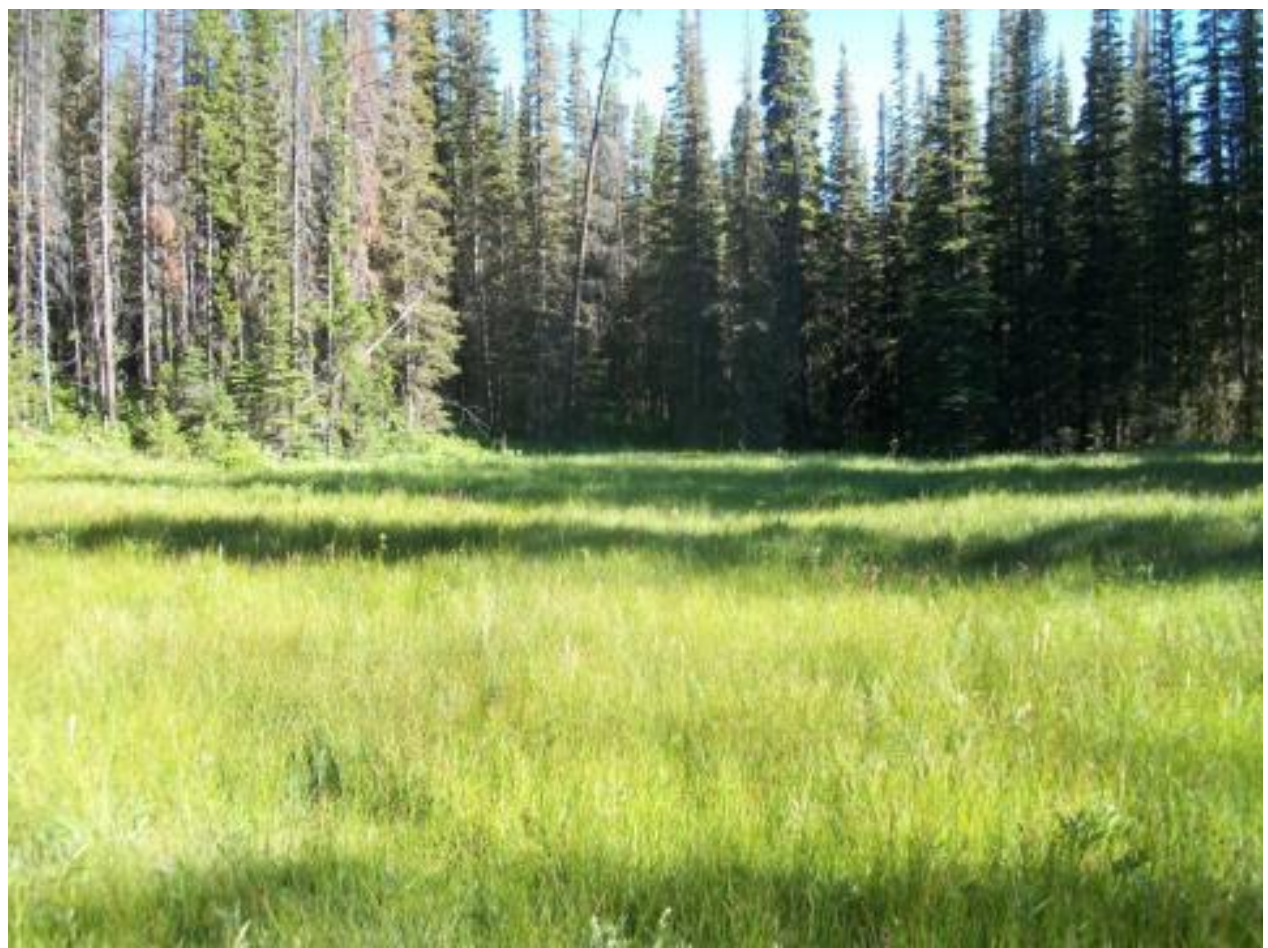

Figure 22. A Rocky Mountain Subalpine-Montane Wet Meadow sampled as part of the Blackfoot-Swan Intensification Project. 


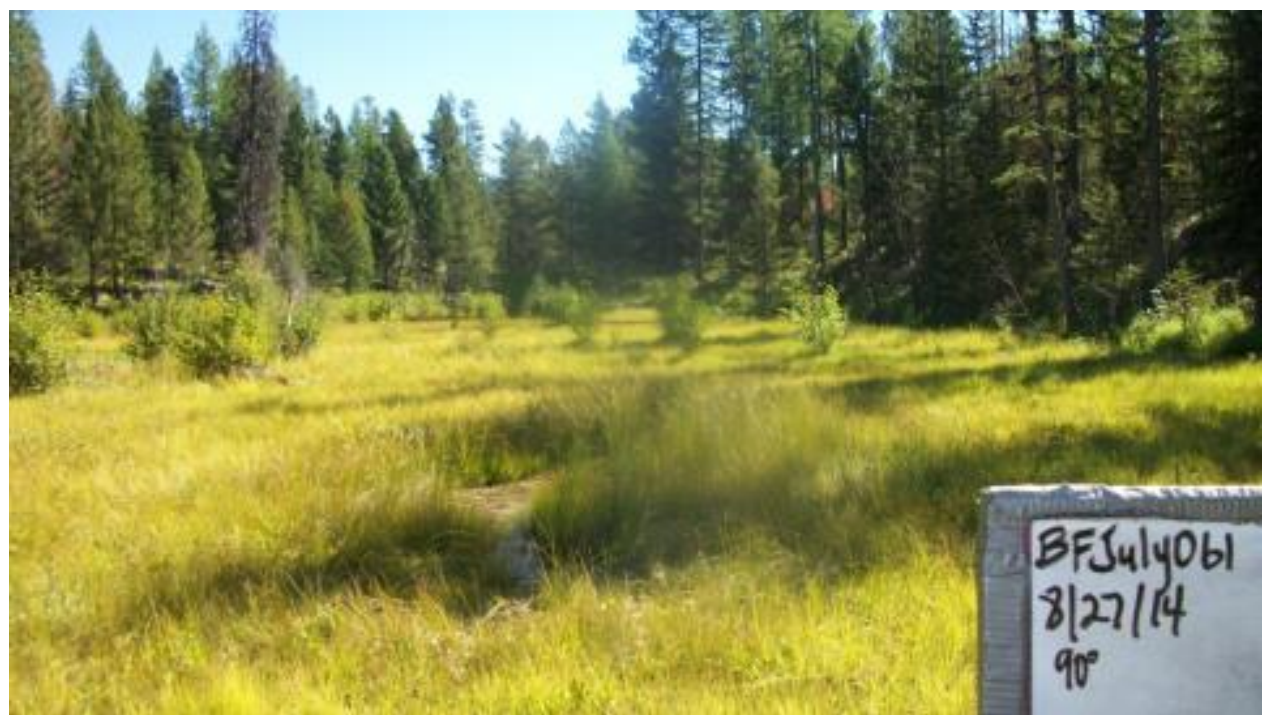

Figure 23. A Rocky Mountain Subalpine-Montane Fen sampled as part of the Blackfoot-Swan Intensification project.

Wetlands sampled were also classified by hydrogeomorphic (HGM) system in the field. The slope HGM class was assigned most frequently (61 sites), although depressional wetlands were also common (53 sites; Table 10). Hydrology of these slope wetlands was largely dominated by seeps and springs.

Table 10. Sampled wetlands by hydrogeomorphic system in the Blackfoot-Swan Intensification Project area.

\begin{tabular}{lc} 
Hydrogeomorphic System & $\begin{array}{c}\text { Number of Sites } \\
\text { Surveyed }\end{array}$ \\
\hline Depressional & 53 \\
Lacustrine Fringe & 1 \\
Riverine & 11 \\
Slope & 61 \\
& \\
Total & 126 \\
\hline
\end{tabular}

Level 2 condition scores were calculated for all 126 wetlands sampled. Scores ranged from 52100 out of a possible range of 21.5-100. We divided our assessment scores into four categories defined relative to their departure from reference standard: 1) at or near expected reference standard (scores $=90-100) ; 2$ ) slight departure from expected reference standard (scores $=80$ 89 ); 3 ) moderate departure from expected reference standard (scores $=70-79$ ); and 4) severe departure from expected reference standard (scores $<70$ ). Most sites were either at or near the reference standard, or slightly departed from reference (Figure 24, Table 11). 


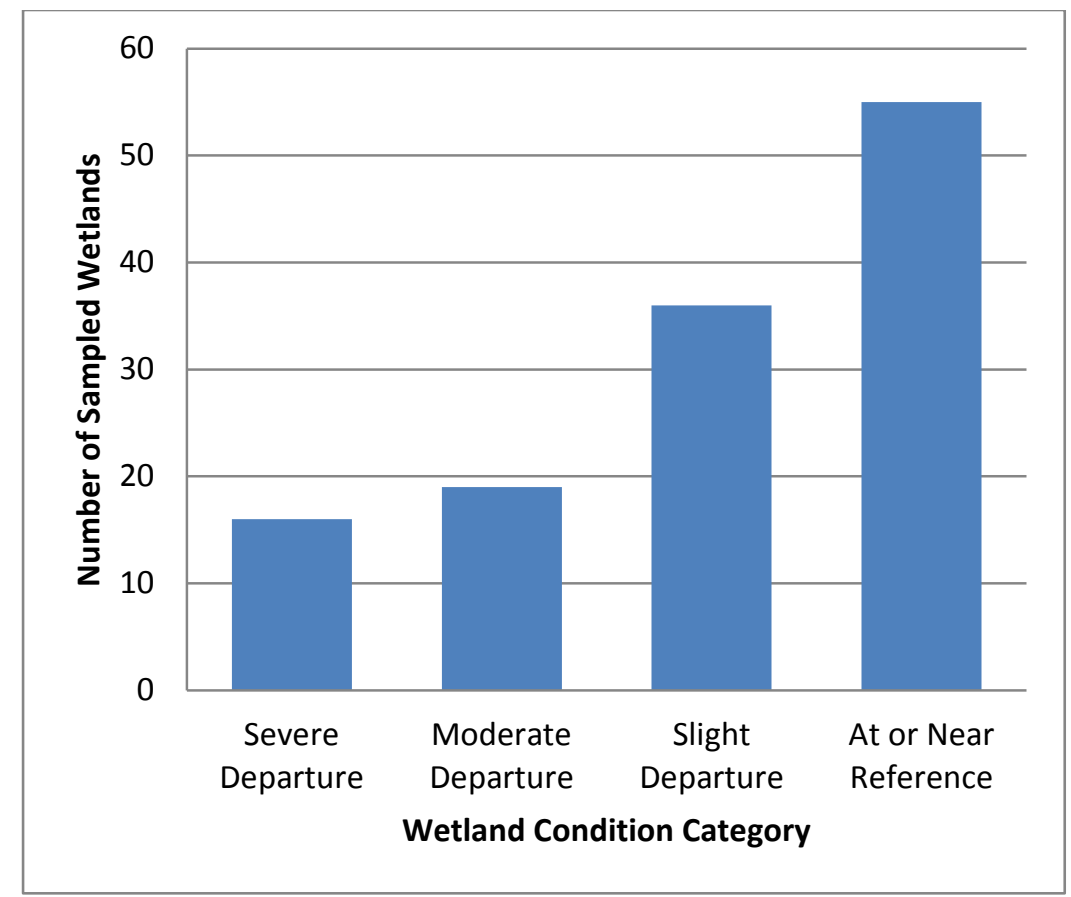

Figure 24. Level 2 assessment condition categories for wetlands assessed as part of the Blackfoot-Swan Intensification Project. Condition categories are relative to reference standard.

Table 11. Wetland condition category by wetland ecological system for 126 sampled wetlands in the Blackfoot-Swan Intensification Project area. Condition categories are interpreted as at or near reference standard and slight, moderate, and severe departure from reference standard.

\begin{tabular}{lrrrr}
\hline \multirow{2}{*}{ Ecological System } & \multicolumn{3}{c}{ Wetland Condition Category } \\
& $\begin{array}{c}\text { At or Near } \\
\text { Reference }\end{array}$ & $\begin{array}{c}\text { Slight } \\
\text { Departure }\end{array}$ & $\begin{array}{c}\text { Moderate } \\
\text { Departure }\end{array}$ & $\begin{array}{c}\text { Severe } \\
\text { Departure }\end{array}$ \\
\hline Intermontane Pothole & 8 & 15 & 6 & 8 \\
Northern RM* Lower Montane Riparian & 4 & 6 & 5 & 1 \\
Woodland and Shrubland & & & & \\
Northern RM Conifer Swamp & 1 & 2 & 1 & \\
Northern RM Wooded Vernal Pool & & 5 & 3 & 3 \\
RM Alpine-Montane Wet Meadow & 12 & 3 & 1 & \\
RM Subalpine-Montane Fen & 22 & 4 & 2 & 1 \\
RM Subalpine-Montane Riparian Shrubland & 3 & 1 & & \\
RM Subalpine-Montane Riparian Woodland & 1 & & & \\
Western North American Emergent Marsh & 4 & 1 & 19 & 16 \\
\hline Totals & 55 & 36 & & \\
\hline
\end{tabular}

The scores for each of the four attributes comprising the overall condition score (Landscape Context, Vegetation, Physicochemical, and Hydrologic attributes) showed variable patterns (Table 12). Sites were most likely to be at or near reference conditions for the Hydrologic attribute, followed by the Landscape Context attribute. 
Table 12. Ecological Integrity Assessment (EIA) attribute condition category by wetland ecological system for the Blackfoot-Swan Intensification Project area. Condition categories are interpreted as at or near reference standard and slight, moderate, and severe departure from reference standard.

\begin{tabular}{|c|c|c|c|c|}
\hline & \multicolumn{4}{|c|}{ Condition Category } \\
\hline & $\begin{array}{l}\text { At or Near } \\
\text { Reference }\end{array}$ & Slight & Moderate & Severe \\
\hline Landscape Context Attribute & 68 & 17 & 17 & 24 \\
\hline Intermontane Pothole & 21 & 2 & 5 & 9 \\
\hline Northern RM Lower Montane Riparian Woodland and Shrubland & 3 & 4 & 5 & 4 \\
\hline Northern RM Conifer Swamp & 1 & & 1 & \\
\hline Northern Rocky Mountain Wooded Vernal Pool & & 1 & 1 & 1 \\
\hline Rocky Mountain Alpine-Montane Wet Meadow & 17 & 1 & & 5 \\
\hline Rocky Mountain Subalpine-Montane Fen & 17 & 6 & 2 & 1 \\
\hline Rocky Mountain Subalpine-Montane Riparian Shrubland & 4 & 2 & 2 & 2 \\
\hline Rocky Mountain Subalpine-Montane Riparian Woodland & 1 & & & \\
\hline Western North American Emergent Marsh & 4 & 1 & 1 & 2 \\
\hline Vegetation Attribute & 37 & 47 & 21 & 21 \\
\hline Intermontane Pothole & 7 & 10 & 11 & 9 \\
\hline Northern RM Lower Montane Riparian Woodland and Shrubland & 5 & 6 & 2 & 3 \\
\hline Northern RM Conifer Swamp & & 1 & & 1 \\
\hline Northern Rocky Mountain Wooded Vernal Pool & & 2 & & 1 \\
\hline Rocky Mountain Alpine-Montane Wet Meadow & 5 & 11 & 2 & 5 \\
\hline Rocky Mountain Subalpine-Montane Fen & 14 & 8 & 4 & \\
\hline Rocky Mountain Subalpine-Montane Riparian Shrubland & 2 & 4 & 2 & 2 \\
\hline Rocky Mountain Subalpine-Montane Riparian Woodland & 1 & & & \\
\hline Western North American Emergent Marsh & 3 & 5 & & \\
\hline Physicochemical Attribute & 51 & 25 & 17 & 33 \\
\hline Intermontane Pothole & 4 & 7 & 7 & 19 \\
\hline Northern RM Lower Montane Riparian Woodland and Shrubland & 7 & 3 & 1 & 5 \\
\hline Northern RM Conifer Swamp & 1 & & 1 & \\
\hline Northern Rocky Mountain Wooded Vernal Pool & & 2 & & 1 \\
\hline Rocky Mountain Alpine-Montane Wet Meadow & 10 & 5 & 4 & 4 \\
\hline Rocky Mountain Subalpine-Montane Fen & 21 & 2 & 1 & 2 \\
\hline Rocky Mountain Subalpine-Montane Riparian Shrubland & 4 & 4 & 1 & 1 \\
\hline Rocky Mountain Subalpine-Montane Riparian Woodland & & 1 & & \\
\hline Western North American Emergent Marsh & 4 & 1 & 2 & 1 \\
\hline Hydrologic Attribute & 103 & 7 & 6 & 10 \\
\hline Intermontane Pothole & 35 & & & 2 \\
\hline Northern RM Lower Montane Riparian Woodland and Shrubland & 12 & 2 & & 2 \\
\hline Northern RM Conifer Swamp & 1 & 1 & & \\
\hline Northern Rocky Mountain Wooded Vernal Pool & 3 & & & \\
\hline Rocky Mountain Alpine-Montane Wet Meadow & 17 & 2 & 1 & 3 \\
\hline Rocky Mountain Subalpine-Montane Fen & 23 & 2 & 1 & \\
\hline Rocky Mountain Subalpine-Montane Riparian Shrubland & 6 & & 4 & \\
\hline Rocky Mountain Subalpine-Montane Riparian Woodland & 1 & & & \\
\hline Western North American Emergent Marsh & 5 & & & 3 \\
\hline
\end{tabular}


Although most of the Intermontane Pothole sites were at or near reference conditions for the Hydrologic attribute, their scores were much more variable for the other attributes, most notably the Physicochemical attribute (with 19 of 37 sites showing a severe departure from reference conditions). This was largely due to reduced soil surface integrity caused by heavy grazing, especially near the drier sites. The Rocky Mountain Subalpine-Montane Fens tended toward relatively high scores across all four attributes, whereas scores were more variable for Rocky Mountain Alpine-Montane Wet Meadows.

\subsection{Stressors}

The scope and severity of each observed stressor were recorded both within the AA and within a 200-m envelope around the AA to help identify potential impacts to wetland condition. Fewer stressors were recorded in the AA than in the 200-m envelope around the AA (Table 13). This is partially attributable to the requirement that at least $90 \%$ of the AA be placed within a wetland, so stressors like paved roads cannot be included in an AA. Thirty-eight of the 126 sites had no observed stressors in the AA, and 17 sites had no observed stressors within the 200-m envelope. Most stressor impact ratings fell into the Minimal to No Impact and Low Impact categories at both scales (Tables 14 and 15). No site's impact rating was categorized as Very High, although five sites (two in the AA and three in the 200-m envelope) received High impact ratings. When examined by EIA attribute, impact scores tended to be highest for the Landscape Context and Vegetation attributes within both the AA and the 200-m envelope (Tables 16 and 17). The Physicochemical attribute made the least contribution to higher impact scores, with nearly all sites falling in the No Impact and Low Impact categories.

Recreation/human visitation and livestock grazing were the most common stressors potentially impacting Landscape Context within the AA. While they were also common within the 200-m envelope, unpaved roads were the most observed stressor there. Intensive or selective logging was also noted at many sites, as were beetle-killed Pinus and other diseased conifers. Vegetation stressors included browsing by native ungulates, livestock grazing, and beaver activity. Beaver activity was also the most common Hydrologic stressor, along with impoundments. Trash or refuse dumping was the most common Physicochemical stressor. 
Table 13. Stressors observed in the assessment area (AA) and the 200-m envelope around the AA and the corresponding number of sampled wetland sites, categorized by Ecological Integrity Assessment (EIA) attribute. Note that some stressors are considered to impact more than one attribute.

\begin{tabular}{|c|c|c|}
\hline \multirow[b]{2}{*}{ Landscape Context } & \multicolumn{2}{|c|}{ Number of Sites } \\
\hline & $\mathbf{A A}$ & $200 \mathrm{~m}$ \\
\hline Paved surfaces & -- & 13 \\
\hline Unpaved roads & 7 & 55 \\
\hline Domestic or commercial development & -- & 5 \\
\hline Recreation or human visitation & 22 & 41 \\
\hline Livestock grazing & 31 & 35 \\
\hline Irrigated cropland & -- & 1 \\
\hline Irrigated hay pasture & 1 & 2 \\
\hline Irrigation ditches & -- & 1 \\
\hline Disturbed fallow lands dominated by exotic species & -- & 1 \\
\hline Fallow fields (no human use in past 10 years) & -- & 1 \\
\hline Fences & 4 & 5 \\
\hline Intensive logging & 8 & 21 \\
\hline Selective logging & 12 & 26 \\
\hline Beetle-killed Pinus species & 2 & 12 \\
\hline Other diseased conifers & 5 & 22 \\
\hline Recent fire $(<5$ years $)$ & 1 & 1 \\
\hline Potential for agricultural runoff & 1 & 1 \\
\hline Potential for urban runoff & 3 & 3 \\
\hline \multicolumn{3}{|l|}{ Vegetation } \\
\hline Livestock grazing & 31 & 35 \\
\hline Vegetation conversion & 1 & 1 \\
\hline Mechanical vegetation removal & -- & 1 \\
\hline Recent fire $(<5$ years $)$ & 1 & 1 \\
\hline Evidence of intentional burning & 1 & 2 \\
\hline Browsing of woody vegetation by native ungulates & 52 & 58 \\
\hline Beaver activity & 17 & 16 \\
\hline \multicolumn{3}{|l|}{ Physicochemical } \\
\hline Filling or dumping of sediment or fill & 1 & 2 \\
\hline Trash or refuse dumping & 4 & 13 \\
\hline Gravel pits, open pit mining & 1 & 1 \\
\hline Other mining activity & -- & 1 \\
\hline Chemical vegetation control & -- & 1 \\
\hline Mechanical vegetation removal & -- & 1 \\
\hline \multicolumn{3}{|l|}{ Hydrologic } \\
\hline Impoundment of flowing water & 9 & 15 \\
\hline Culvert & 4 & 6 \\
\hline Upstream dam & 1 & 2 \\
\hline Engineered channel (e.g., riprap) & -- & 1 \\
\hline Pumps, diversions, or ditches that move water into wetland & 2 & 3 \\
\hline Pumps, diversions, or ditches that move water out of wetland & 4 & 6 \\
\hline Berms/Dikes/Levees & 5 & 5 \\
\hline Beaver activity & 17 & 16 \\
\hline
\end{tabular}


Table 14. Count of overall assessment area (AA) stressor impact ratings by wetland ecological system for the Blackfoot-Swan Intensification Project area.

\begin{tabular}{|c|c|c|c|c|c|c|}
\hline & \multicolumn{5}{|c|}{ Impact Rating $^{\mathrm{a}}$} & \multirow[b]{2}{*}{ \# Sites } \\
\hline & $\begin{array}{c}\text { Minimal } \\
\text { to No } \\
\text { Impact }\end{array}$ & Low & Medium & High & $\begin{array}{l}\text { Very } \\
\text { High }\end{array}$ & \\
\hline Intermontane Pothole & 29 & 6 & 1 & 1 & & 37 \\
\hline $\begin{array}{l}\text { Northern RM Lower Montane Riparian } \\
\text { Woodland and Shrubland }\end{array}$ & 10 & 5 & 1 & & & 16 \\
\hline Northern RM Conifer Swamp & 1 & 1 & & & & 2 \\
\hline Northern RM Wooded Vernal Pool & 3 & & & & & 3 \\
\hline RM Alpine-Montane Wet Meadow & 15 & 6 & 1 & 1 & & 23 \\
\hline RM Subalpine-Montane Fen & 21 & 4 & 1 & & & 26 \\
\hline RM Subalpine-Montane Riparian Shrubland & 4 & 4 & 2 & & & 10 \\
\hline RM Subalpine-Montane RiparianWoodland & & & 1 & & & 1 \\
\hline Western North American Emergent Marsh & 5 & 1 & 2 & & & 8 \\
\hline
\end{tabular}

${ }^{\mathrm{a}}$ Overall impact rating values were rounded to create five classes.

Table 15. Overall stressor impact rating within the 200-m envelope around the assessment area (AA) by wetland ecological system for the Blackfoot-Swan Intensification Project area.

\begin{tabular}{|c|c|c|c|c|c|c|}
\hline \multirow[b]{3}{*}{ Intermontane Pothole } & \multicolumn{5}{|c|}{ Impact Rating $^{\mathrm{a}}$} & \multirow[b]{2}{*}{ \# Sites } \\
\hline & $\begin{array}{c}\text { Minimal } \\
\text { to No } \\
\text { Impact }\end{array}$ & Low & Medium & High & $\begin{array}{l}\text { Very } \\
\text { High }\end{array}$ & \\
\hline & 21 & 13 & 3 & & & 37 \\
\hline $\begin{array}{l}\text { Northern RM Lower Montane Riparian } \\
\text { Woodland and Shrubland }\end{array}$ & 8 & 7 & 1 & & & 16 \\
\hline Northern RM Conifer Swamp & & 2 & & & & 2 \\
\hline Northern RM Wooded Vernal Pool & 2 & 1 & & & & 3 \\
\hline RM Alpine-Montane Wet Meadow & 13 & 8 & & 2 & & 23 \\
\hline RM Subalpine-Montane Fen & 17 & 8 & 1 & & & 26 \\
\hline RM Subalpine-Montane Riparian Shrubland & & 8 & 1 & 1 & & 10 \\
\hline RM Subalpine-Montane RiparianWoodland & & 1 & & & & 1 \\
\hline Western North American Emergent Marsh & 2 & 3 & 3 & & & 8 \\
\hline
\end{tabular}

${ }^{\mathrm{a}}$ Overall impact rating values were rounded to create five classes. 
Table 16. Ecological Integrity Assessment (EIA) attribute stressor impact rating within the assessment area (AA) by wetland ecological system for the Blackfoot-Swan Intensification Project area. RM = Rocky Mountain.

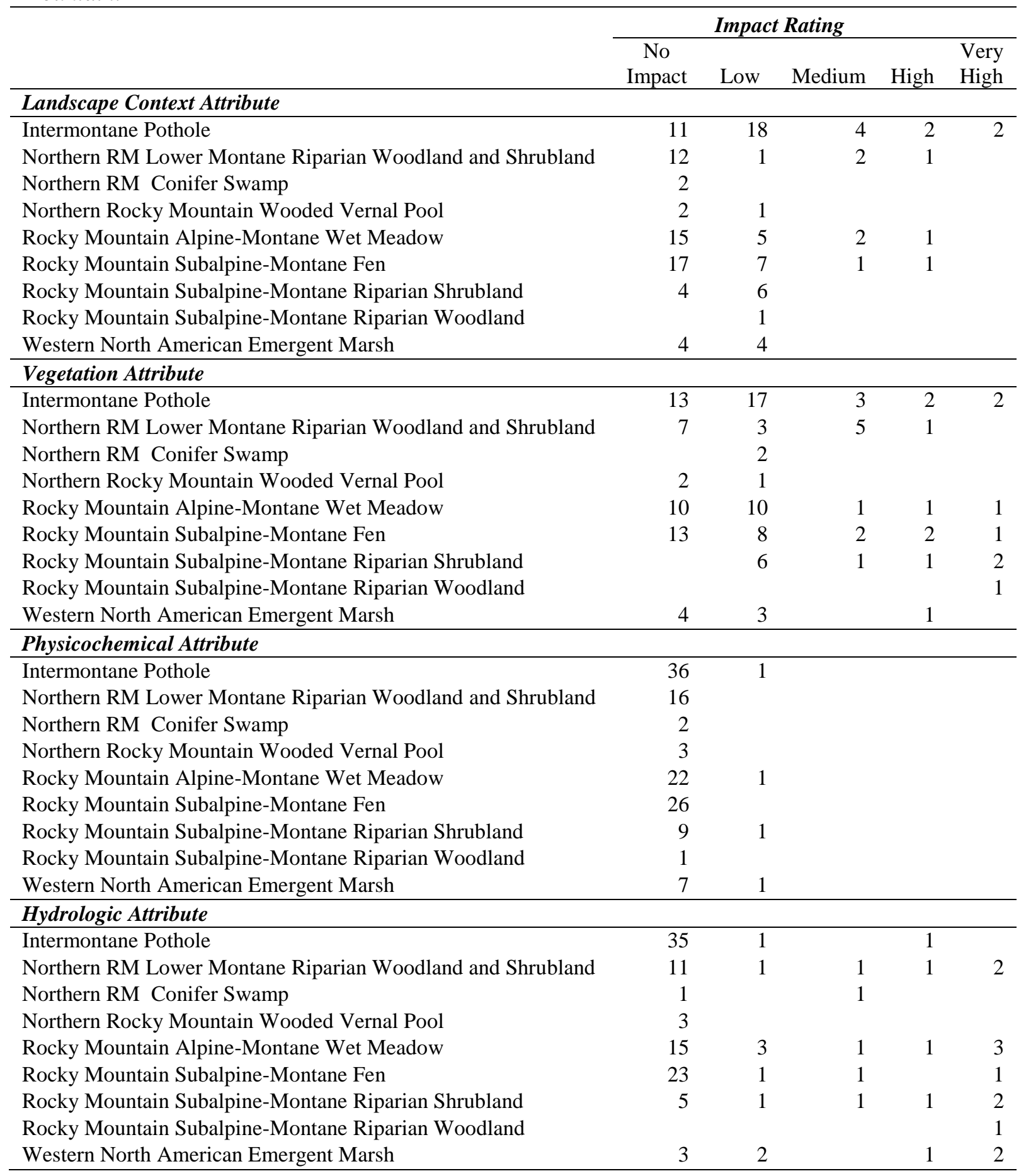


Table 17. Ecological Integrity Assessment (EIA) attribute stressor impact rating within the 200-m envelope around the assessment area (AA) by wetland ecological system for the Blackfoot-Swan Intensification Project area. RM= Rocky Mountain.

\begin{tabular}{|c|c|c|c|c|c|}
\hline & \multicolumn{4}{|c|}{ Impact Rating } & \multirow[b]{2}{*}{$\begin{array}{l}\text { Very } \\
\text { High }\end{array}$} \\
\hline & $\begin{array}{c}\text { No } \\
\text { Impact }\end{array}$ & Low & Medium & High & \\
\hline \multicolumn{6}{|l|}{ Landscape Context Attribute } \\
\hline Intermontane Pothole & 7 & 12 & 12 & 4 & 2 \\
\hline Northern RM Lower Montane Riparian Woodland and Shrubland & 3 & 6 & 5 & 2 & \\
\hline Northern RM Conifer Swamp & & 2 & & & \\
\hline Northern Rocky Mountain Wooded Vernal Pool & & 2 & 1 & & \\
\hline Rocky Mountain Alpine-Montane Wet Meadow & 5 & 10 & 4 & 3 & 1 \\
\hline Rocky Mountain Subalpine-Montane Fen & 4 & 15 & 2 & 4 & 1 \\
\hline Rocky Mountain Subalpine-Montane Riparian Shrubland & & 3 & 5 & 1 & 1 \\
\hline Rocky Mountain Subalpine-Montane Riparian Woodland & & 1 & & & \\
\hline Western North American Emergent Marsh & 3 & & 3 & 1 & 1 \\
\hline \multicolumn{6}{|l|}{ Vegetation Attribute } \\
\hline Intermontane Pothole & 13 & 11 & 8 & 3 & 2 \\
\hline Northern RM Lower Montane Riparian Woodland and Shrubland & 7 & 5 & 3 & 1 & \\
\hline Northern RM Conifer Swamp & & 2 & & & \\
\hline Northern Rocky Mountain Wooded Vernal Pool & 2 & 1 & & & \\
\hline Rocky Mountain Alpine-Montane Wet Meadow & 9 & 10 & 2 & 1 & 1 \\
\hline Rocky Mountain Subalpine-Montane Fen & 11 & 11 & 1 & 2 & 1 \\
\hline Rocky Mountain Subalpine-Montane Riparian Shrubland & & 7 & 1 & 2 & \\
\hline Rocky Mountain Subalpine-Montane Riparian Woodland & & 1 & & & \\
\hline Western North American Emergent Marsh & 3 & 1 & 1 & 3 & \\
\hline \multicolumn{6}{|l|}{ Physicochemical Attribute } \\
\hline Intermontane Pothole & 36 & 1 & & & \\
\hline Northern RM Lower Montane Riparian Woodland and Shrubland & 15 & & 1 & & \\
\hline Northern RM Conifer Swamp & 1 & 1 & & & \\
\hline Northern Rocky Mountain Wooded Vernal Pool & 3 & & & & \\
\hline Rocky Mountain Alpine-Montane Wet Meadow & 19 & 4 & & & \\
\hline Rocky Mountain Subalpine-Montane Fen & 25 & 1 & & & \\
\hline Rocky Mountain Subalpine-Montane Riparian Shrubland & 6 & 2 & 1 & & 1 \\
\hline Rocky Mountain Subalpine-Montane Riparian Woodland & 1 & & & & \\
\hline Western North American Emergent Marsh & 4 & 4 & & & \\
\hline \multicolumn{6}{|l|}{ Hydrologic Attribute } \\
\hline Intermontane Pothole & 35 & & & 1 & 1 \\
\hline Northern RM Lower Montane Riparian Woodland and Shrubland & 9 & 4 & 1 & & 2 \\
\hline Northern RM Conifer Swamp & 1 & & 1 & & \\
\hline Northern Rocky Mountain Wooded Vernal Pool & 3 & & & & \\
\hline Rocky Mountain Alpine-Montane Wet Meadow & 16 & 3 & 2 & & 2 \\
\hline Rocky Mountain Subalpine-Montane Fen & 20 & 4 & 2 & & \\
\hline Rocky Mountain Subalpine-Montane Riparian Shrubland & 5 & 2 & 1 & 2 & \\
\hline Rocky Mountain Subalpine-Montane Riparian Woodland & & 1 & & & \\
\hline Western North American Emergent Marsh & 3 & 1 & 1 & 2 & 1 \\
\hline
\end{tabular}




\subsection{Level 3 Assessments}

We completed 24 Level 3 intensive assessments within the project area, encountering 309 plant taxa. Of these, 282 taxa were identified to the species level. Of the 309 total plant taxa encountered, 125 species were encountered at only one site and 49 species were encountered at only two sites. The average number of species encountered per site was 34 (range 7-76). Of the 282 taxa identified to species, $260(92 \%)$ were native species and $19(7 \%)$ were exotic species. Two species were classified as "native/exotic" (Prunella vulgaris and Poa palustris), and one was classified as "unknown/undetermined" (Chenopodium watsonii).

The most commonly encountered plant species was common beaked sedge (Carex utriculata; Table 18). This species is an obligate wetland species that inhabits a variety of wetland systems in the northern half of North America.

Table 18. Most commonly encountered plant species during Level 3 intensive assessments in the Blackfoot-Swan Intensification Project area.

\begin{tabular}{|c|c|c|c|c|c|}
\hline Scientific Name & Common name & $\begin{array}{c}\text { Number of } \\
\text { Sites } \\
\text { Encountered }\end{array}$ & C-Value & $\begin{array}{c}\text { Wetland } \\
\text { Indicator } \\
\text { Status }\end{array}$ & Native Status \\
\hline Carex utriculata & $\begin{array}{l}\text { common beaked } \\
\text { sedge }^{\mathrm{a}}\end{array}$ & 20 & 3 & OBL & Native \\
\hline Salix drummondiana & Drummond's willow & 11 & 5 & FACW & Native \\
\hline Symphoricarpos albus & common snowberry & 10 & 3 & UPL & Native \\
\hline Fragaria virginiana & Virginia strawberry & 10 & 3 & FACU & Native \\
\hline Eleocharis palustris & creeping spikerush & 10 & 4 & OBL & Native \\
\hline Picea engelmannii & Engelmann spruce & 10 & 4 & FAC & Native \\
\hline Galium triflorum & $\begin{array}{l}\text { sweet-scent bedstraw } \\
\text { starry false }\end{array}$ & 10 & 6 & FACU & Native \\
\hline Smilacina stellata & Solomon's-seal & 10 & 4 & FACU & Native \\
\hline Cirsium arvense & Canada thistle & 10 & 0 & FACU & Exotic \\
\hline Phalaris arundinaceae & reed canarygrass & 10 & 0 & FACW & Exotic \\
\hline Angelica arguta & Lyall's angelica & 10 & 5 & NA & Native \\
\hline
\end{tabular}

${ }^{a}$ Alternate common name Northwest Territory sedge 


\subsection{Floristic Quality Assessment}

We calculated floristic quality assessment (FQA) metrics for all 24 Level 3 assessment sites (Table 19). These metrics can be used as a measure of biotic condition. Mean C-value across these sites was $4.91+0.76 \mathrm{SD}$ (range $3.44-6.34$ ). Most C-values for native species encountered fell between 3 and 8 (Figure 25). Species at the lower end of that range are found in a range of habitats with little to moderate disturbance, while those at the higher end tend to be habitat specialists or have low tolerance for disturbance.

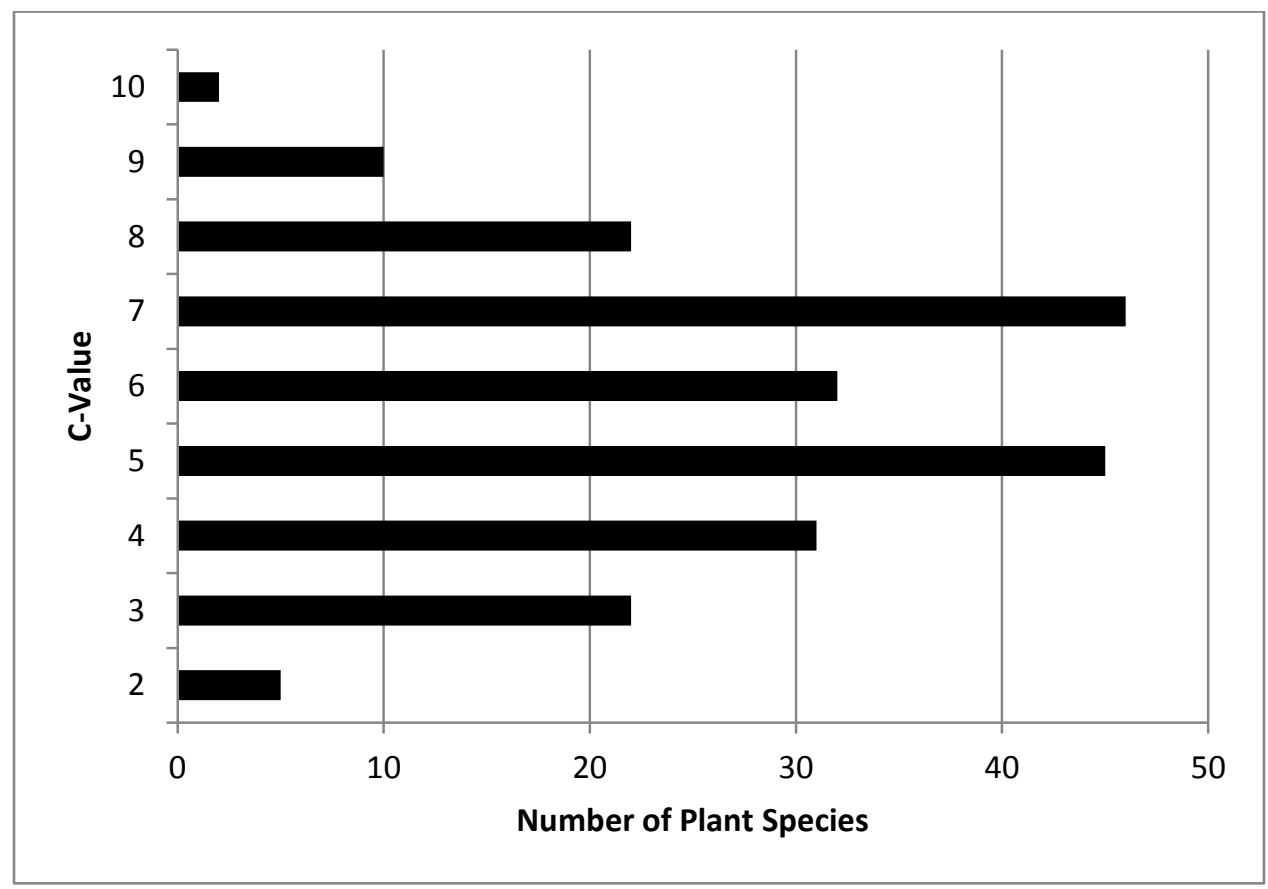

Figure 25. Frequency distribution of C-values of native plant species encountered during Level 3 assessments in the Blackfoot-Swan Intensification Project area.

\subsection{Comparisons of Level 2 \& 3 Results}

To understand the effectiveness of this assessment framework in determining the condition of wetlands in the Blackfoot-Swan Intensification Project area, we compared Level 3 assessment results with Level 2 assessment results.

Impact ratings within the AA and within the 200-m envelope around the AA showed moderate correlations with overall Level 2 assessment scores $(r=0.36$ and $r=0.38$, respectively; Tables 20 and 21). The Landscape Context and Hydrologic attribute scores were most strongly correlated with overall impact rating for both the AA and the 200-m envelope (with $\mathrm{r}$ values ranging from 0.35-0.54). In general, the Landscape Context and Hydrologic attribute scores tended toward stronger correlations with impact scores calculated within the 200-m envelope than with those calculated within the AA itself. The reverse was true for the Vegetation and Physicochemical attributes, although the trend was not as strong or consistent. 
Table 19. Means and standard deviations of all floristic quality assessment (FQA) metrics considered by Ecological System for Level 3 assessments completed in the Blackfoot-Swan Intensification Project area.

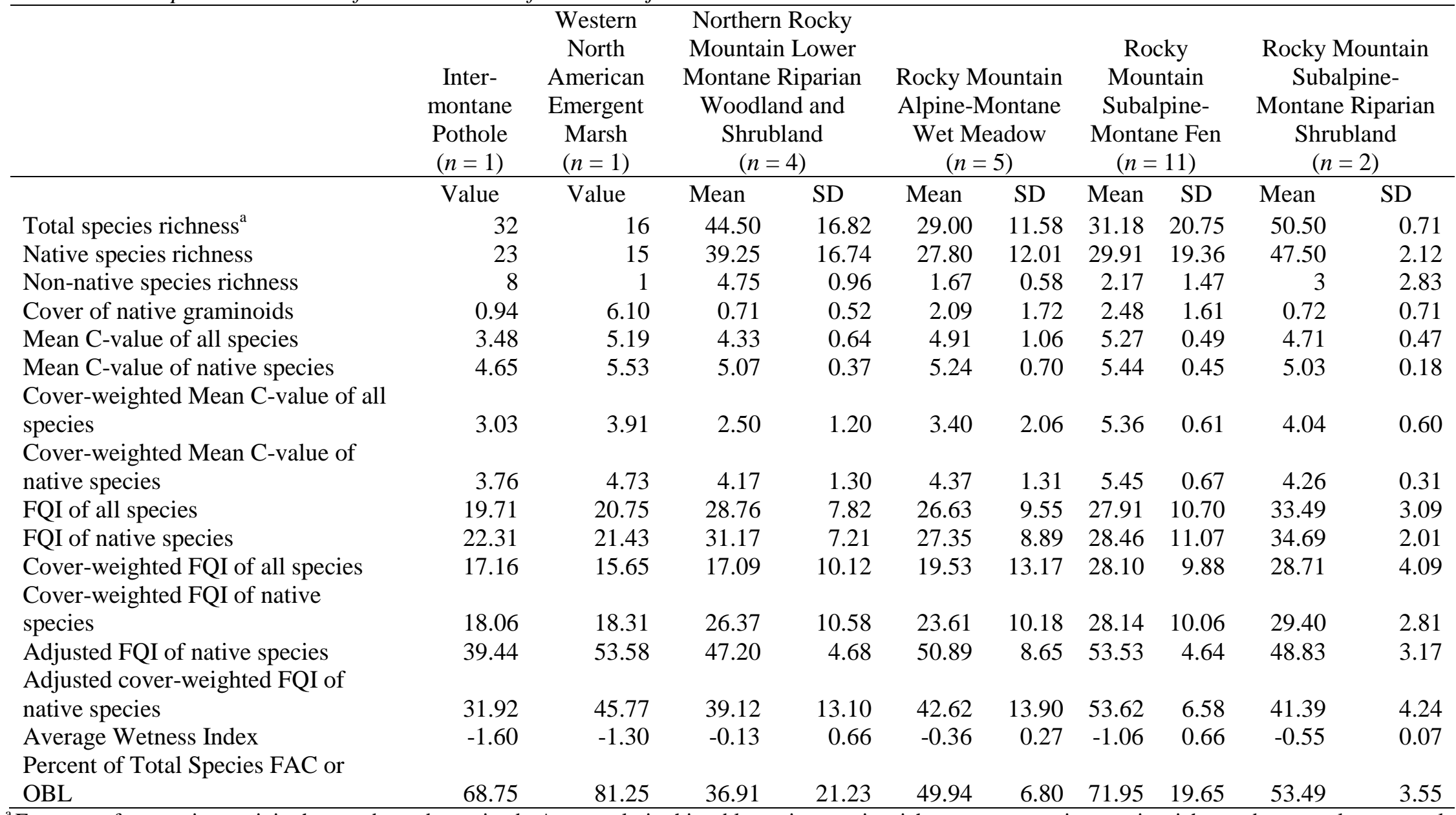

${ }^{\mathrm{a}}$ For a very few species, nativity has not been determined. As a result, in this table, native species richness + non-native species richness does not always equal total species richness. 
Table 20. Spearman's correlation coefficients of Impact Category scores calculated within the assessment area $(A A)$ with Level 2 assessment attribute and overall scores.

\begin{tabular}{lrrrrr}
\hline & \multicolumn{5}{c}{ Level 2 Assessment Scores } \\
\cline { 2 - 6 } Impact Category & $\begin{array}{c}\text { Landscape } \\
\text { Context }\end{array}$ & Vegetation & $\begin{array}{c}\text { Physico- } \\
\text { chemical }\end{array}$ & Hydrologic & $\begin{array}{c}\text { Overall } \\
\text { Condition }\end{array}$ \\
\hline Landscape Context & 0.35 & 0.16 & 0.41 & 0.14 & 0.37 \\
Vegetation & 0.17 & 0.22 & 0.07 & 0.17 & 0.16 \\
Physicochemical & 0.17 & 0.09 & 0.02 & 0.52 & 0.20 \\
Hydrologic & 0.19 & 0.07 & 0.03 & 0.15 & 0.15 \\
Overall Impact Rating & 0.35 & 0.25 & 0.22 & 0.40 & 0.36 \\
\hline
\end{tabular}

Table 21. Spearman's correlation coefficients of Impact Category scores calculated within a 200-m envelope of the assessment area with Level 2 assessment attribute and overall scores.

\begin{tabular}{lrrrrr}
\hline & \multicolumn{5}{c}{ Level 2 Assessment Scores } \\
\cline { 2 - 6 } Impact Category & $\begin{array}{c}\text { Landscape } \\
\text { Context }\end{array}$ & Vegetation & $\begin{array}{c}\text { Physico- } \\
\text { chemical }\end{array}$ & Hydrologic & $\begin{array}{c}\text { Overall } \\
\text { Condition }\end{array}$ \\
\hline Landscape Context & 0.64 & 0.19 & 0.27 & 0.47 & 0.47 \\
Vegetation & 0.24 & 0.21 & 0.14 & 0.26 & 0.24 \\
Physicochemical & 0.23 & 0.04 & -0.04 & 0.65 & 0.21 \\
Hydrologic & 0.28 & $<0.01$ & 0.03 & 0.42 & 0.20 \\
Overall Impact Rating & 0.48 & 0.17 & 0.15 & 0.54 & 0.38 \\
\hline
\end{tabular}

We evaluated 16 vegetation metrics in the FQA. Several of these metrics were highly correlated $(r \geq 0.9)$ with each other (Table 22). Most of the vegetation metrics showed some degree of correlation with either stressors or overall wetland condition (Table 23), but none of the correlations was strong. The strongest correlation was observed between mean $\mathrm{C}$-value of native species and overall condition score $(\mathrm{r}=0.54)$. Non-native species richness was negatively correlated with stressor impact scores and overall condition scores, meaning that as impact and condition scores increased toward their maximum values (indicating reference conditions on the ground), the number of non-native species decreased.

FQA metrics that were correlated with overall condition scores also were correlated with one or more individual Level 2 attribute scores (Table 24). Not surprisingly, nearly all FQA metrics showed moderate correlation with the Vegetation attribute. Again, non-native species richness was negatively correlated with all four attributes, meaning that as EIA attribute scores increased toward 100 (reference conditions), non-native species richness decreased. 
Table 22. Spearman's correlation coefficients of metrics included in the floristic quality assessment (FQA) for the Blackfoot-Swan Intensification Project. Correlation coefficients of 0.90 or greater are in bold.

\begin{tabular}{|c|c|c|c|c|c|c|c|c|c|c|c|c|c|c|c|c|}
\hline & $\begin{array}{c}\text { Total } \\
\text { species } \\
\text { richness }\end{array}$ & $\begin{array}{c}\text { Native } \\
\text { species } \\
\text { richness }\end{array}$ & $\begin{array}{c}\text { Non- } \\
\text { native } \\
\text { species } \\
\text { richness } \\
\end{array}$ & $\begin{array}{l}\text { Cover of } \\
\text { native } \\
\text { graminoids }\end{array}$ & $\begin{array}{l}\text { Mean } \\
\text { C- } \\
\text { value, } \\
\text { all } \\
\text { species }\end{array}$ & $\begin{array}{c}\text { Mean } \\
\text { C- } \\
\text { value, } \\
\text { native } \\
\text { species }\end{array}$ & $\begin{array}{l}\text { Cover- } \\
\text { weighted } \\
\text { mean C- } \\
\text { value, all } \\
\text { species } \\
\end{array}$ & $\begin{array}{c}\text { Cover- } \\
\text { weighted } \\
\text { mean } \\
\text { C-value, } \\
\text { native } \\
\text { species } \\
\end{array}$ & $\begin{array}{c}\mathrm{FQI}, \\
\text { all } \\
\text { species }\end{array}$ & $\begin{array}{c}\text { FQI, } \\
\text { native } \\
\text { species }\end{array}$ & $\begin{array}{c}\text { Cover- } \\
\text { Weighted } \\
\text { FQI, all } \\
\text { species } \\
\end{array}$ & $\begin{array}{c}\text { Cover- } \\
\text { Weighted } \\
\text { FQI, } \\
\text { native } \\
\text { species } \\
\end{array}$ & $\begin{array}{c}\text { Adjusted } \\
\text { FQI }\end{array}$ & $\begin{array}{c}\text { Adjusted } \\
\text { cover- } \\
\text { weighted } \\
\text { FQI } \\
\end{array}$ & $\begin{array}{c}\text { Wetness } \\
\text { index }\end{array}$ & $\begin{array}{c}\text { Percent of } \\
\text { total } \\
\text { species } \\
\text { FAC or } \\
\text { OBL } \\
\end{array}$ \\
\hline $\begin{array}{l}\text { Total species } \\
\text { richness }\end{array}$ & 1.00 & & & & & & & & & & & & & & & \\
\hline $\begin{array}{l}\text { Native species } \\
\text { richness }\end{array}$ & 0.99 & 1.00 & & & & & & & & & & & & & & \\
\hline $\begin{array}{l}\text { Non-native } \\
\text { species richness }\end{array}$ & 0.46 & 0.37 & 1.00 & & & & & & & & & & & & & \\
\hline $\begin{array}{l}\text { Cover of native } \\
\text { graminoids }\end{array}$ & -0.42 & -0.38 & -0.66 & 1.00 & & & & & & & & & & & & \\
\hline $\begin{array}{l}\text { Mean C-value of } \\
\text { all species }\end{array}$ & -0.13 & -0.04 & -0.77 & 0.56 & 1.00 & & & & & & & & & & & \\
\hline $\begin{array}{l}\text { Mean C-value of } \\
\text { native species }\end{array}$ & 0.10 & 0.16 & -0.38 & 0.33 & 0.83 & 1.00 & & & & & & & & & & \\
\hline $\begin{array}{l}\text { Cover-weighted } \\
\text { mean C-value of } \\
\text { all species }\end{array}$ & -0.08 & -0.01 & -0.56 & 0.51 & 0.63 & 0.36 & 1.00 & & & & & & & & & \\
\hline $\begin{array}{l}\text { Cover-weighted } \\
\text { mean C-value of } \\
\text { native species }\end{array}$ & -0.13 & -0.08 & -0.43 & 0.29 & 0.57 & 0.51 & 0.79 & 1.00 & & & & & & & & \\
\hline $\begin{array}{l}\text { FQI of all } \\
\text { species }\end{array}$ & 0.85 & 0.89 & 0.07 & -0.19 & 0.33 & 0.52 & 0.12 & 0.09 & 1.00 & & & & & & & \\
\hline $\begin{array}{l}\text { FQI of native } \\
\text { species }\end{array}$ & 0.90 & 0.93 & 0.21 & -0.25 & 0.21 & 0.43 & 0.06 & 0.02 & 0.98 & 1.00 & & & & & & \\
\hline $\begin{array}{l}\text { Cover-weighted } \\
\text { FQI of all } \\
\text { species }\end{array}$ & 0.61 & 0.66 & -0.14 & 0.10 & 0.44 & 0.41 & 0.63 & 0.38 & 0.71 & 0.68 & 1.00 & & & & & \\
\hline $\begin{array}{l}\text { Cover-weighted } \\
\text { FQI of native } \\
\text { species }\end{array}$ & 0.82 & 0.85 & 0.14 & -0.23 & 0.26 & 0.44 & 0.35 & 0.39 & 0.86 & 0.86 & 0.83 & 1.00 & & & & \\
\hline Adjusted FQI & -0.06 & 0.03 & -0.65 & 0.52 & 0.97 & 0.91 & 0.58 & 0.59 & 0.41 & 0.30 & 0.45 & 0.35 & 1.00 & & & \\
\hline $\begin{array}{l}\text { Adjusted cover- } \\
\text { weighted FQI }\end{array}$ & -0.16 & -0.11 & -0.50 & 0.37 & 0.62 & 0.51 & 0.85 & 0.99 & 0.08 & 0.01 & 0.41 & 0.36 & 0.63 & 1.00 & & \\
\hline Wetness index & 0.50 & 0.56 & 0.22 & -0.30 & -0.14 & -0.08 & -0.34 & -0.37 & 0.45 & 0.48 & 0.12 & 0.30 & -0.09 & -0.38 & 1.00 & \\
\hline $\begin{array}{l}\text { Percent of total } \\
\text { species FAC or } \\
\text { OBL }\end{array}$ & -0.52 & -0.55 & -0.36 & 0.41 & 0.29 & 0.21 & 0.46 & 0.47 & -0.40 & -0.45 & -0.03 & -0.25 & 0.24 & 0.49 & -0.97 & 1.00 \\
\hline
\end{tabular}


Table 23. Vegetation metrics included in the floristic quality assessment (FQA), and their response to stressors within the assessment area (AA), within the 200-m envelope surrounding the AA, and their relationship with overall wetland condition scores. Response categories are defined as follows: poor correlation refers to metrics with weak correlation $(r<0.3)$ with stressors at either scale and/or overall condition scores, and correlated indicates metrics that show a response ( $r \geq 0.3)$ to either stressors and/or overall wetland condition scores. FQA metrics that were highly correlated $(r \geq 0.9)$ with other FQA metrics were not considered.

\begin{tabular}{|c|c|c|c|c|}
\hline Metric & Response & $\begin{array}{l}\text { Response } \\
\text { to } \\
\text { stressors } \\
\text { (AA) }\end{array}$ & $\begin{array}{l}\text { Response } \\
\text { to } \\
\text { stressors } \\
(200 \mathrm{~m})\end{array}$ & $\begin{array}{l}\text { Overall } \\
\text { Condition } \\
\text { Score }\end{array}$ \\
\hline Non-native species richness & negatively correlated & -0.42 & -0.33 & -0.41 \\
\hline Cover of native graminoids & correlated & 0.44 & 0.21 & 0.43 \\
\hline Mean C-value of native species & correlated & 0.38 & 0.44 & 0.54 \\
\hline Cover-weighted Mean C-value of all species & correlated & 0.43 & 0.21 & 0.33 \\
\hline FQI of native species & correlated & 0.08 & 0.25 & 0.30 \\
\hline Cover-weighted FQI of native species & poor correlation & 0.14 & 0.21 & 0.17 \\
\hline Adjusted cover-weighted FQI of native species & correlated & 0.31 & 0.18 & 0.18 \\
\hline Wetness index & poor correlation & -0.05 & 0.15 & -0.02 \\
\hline
\end{tabular}

Table 24. Spearman's correlation coefficients of floristic quality assessment (FQA) metrics with Level 2 assessment attribute scores for the Blackfoot-Swan Intensification Project. FQA metrics that were highly correlated $(r \geq 0.9)$ with other FQA metrics were not considered.

\begin{tabular}{|c|c|c|c|c|}
\hline & $\begin{array}{c}\text { Landscape } \\
\text { Context }\end{array}$ & Vegetation & $\begin{array}{l}\text { Physico- } \\
\text { Chemical }\end{array}$ & Hydrologic \\
\hline Non-native species richness & -0.35 & -0.38 & -0.34 & -0.38 \\
\hline Cover of native graminoids & 0.23 & 0.40 & 0.49 & 0.36 \\
\hline Mean C-value of native species & 0.38 & 0.56 & 0.45 & 0.32 \\
\hline Cover-weighted mean C-value of all species & -0.07 & 0.47 & 0.42 & 0.13 \\
\hline FQI of native species & $<0.01$ & 0.35 & 0.13 & 0.02 \\
\hline Cover-weighted FQI of native species & -0.08 & 0.29 & 0.08 & -0.04 \\
\hline Adjusted cover-weighted FQI of native species & -0.04 & 0.37 & 0.30 & 0.12 \\
\hline Wetness index & $<0.01$ & -0.29 & 0.02 & 0.07 \\
\hline
\end{tabular}

\subsection{Intermontane Prairie Pothole Descriptions}

Field observation and analysis of assessment scores indicate that Intermontane Prairie Potholes (IPP) are similar to Great Plains Prairie Potholes (GPP) in terms of size, water regime, and graminoid dominance. However, because of differences in underlying substrates and in climatic influences, species composition and distribution are different. These differences support designation of IPPs as a separate Ecological System (Comer et al. 2003) in Montana. The final description of the Intermontane Prairie Potholes can be found in Appendix H. 


\subsection{Wetland Indicator Species and Floristic Quality Assessments}

Coefficients of Conservatism (C-values) are assigned to an individual plant species based on the plant's tolerance to natural and/or human disturbance and its affinity to a specific, unimpaired habitat in a given geographical area. The C-value is a foundational component of Floristic Quality Assessment Index (FQAI) metrics, but is sometimes used alone.

Collectively, the C-values (of a given site) can be used to: 1) identify and prioritize the riparian and wetland sites to conserve, 2) develop baseline conditions, 3) monitor the development of wetland and riparian habitats, 4) determine the species to retain or to plant at a restoration project, and 5) set the restoration targets that achieve a certain quality of habitat. In Montana, Cvalues range from 0 to 10 , with 0 representing non-native species, 1 indicating species with broad habitat affinity and high disturbance tolerance, and 10 representing native species with the strongest affinity to unimpaired habitat in specific areas. The mean $\mathrm{C}$-value for all species that are included in the ACOE's WIS list (and that have an assigned C-value) is 4.17, suggesting that Montana's wetland species are generally tolerant of a moderate range of conditions.

When the WIS list is subset into Wet (OBL and FACW) and Dry (FAC, FACU and UPL), mean $\mathrm{C}$-values are seen to be higher for hydrophytic species. Using values assigned by the National Wetland Plant List for the Great Plains, the mean C-value for OBL and FACW species is 5.55, while for FAC, FACU and UPL species it is 3.45 , reflecting the broader range and higher tolerance of upland species compared to hydrophytes. Using the National Wetland Plant List for the Western Mountains and Valleys, there is a greater difference; the mean C-value for OBL and FACW species is 5.83, while for FAC, FACU and UPL species it is 2.87 .

The next step in our analysis was to identify any correlations between the percentage of wetland species at a given site and individual FQAI metrics. In this study, Table 24 shows a moderate negative correlation (-0.55) between the percentage of FACW or OBL species at a site and its overall native plant richness, and a slightly weaker correlation between the unadjusted FQI of native species and the percentage of hydrophytes (-0.45). Scores on the Adjusted Coverweighted FQI are moderately and positively correlated (0.49) with the proportion of hydrophytes. Mean $\mathrm{C}$ and Mean $\mathrm{C}$ of native species show no significant linear relationship (0.21 and 0.29 respectively) with the percentage of wetland species.

When we analyzed correlations across the larger suite of Level 3 sites assessed in the past five years $(\mathrm{n}=189)$, we saw a stronger positive correlation between Mean $\mathrm{C}$ and Mean $\mathrm{C}$ of native species ( 0.55 and 0.54 , respectively, Table 25$)$. To ensure that this result was not being skewed by the number of fens in previous studies ${ }^{1}$, we removed fens from the dataset and reran the analysis. Again, Mean C and Mean C of native species were moderately correlated with the proportion of FACW and OBL (0.58 and 0.46$)$. We noted, too, that in both cases there was a moderate negative correlation between the proportion of hydrophytes and the number of exotic species. We also saw a moderate correlation between the Adjusted FQI for native species and the proportion of FACW and OBL species at a site.

\footnotetext{
${ }^{1}$ Fens are typically saturated and therefore have more hydrophytic species than drier sites. Moreover, fen-obligate species tend to have higher $\mathrm{C}$-values than more widespread wetland plants.
} 
Table 25. Spearman's correlation coefficients of metrics included in the floristic quality assessment ( $F Q A)$ for the current study and previous studies in Montana ( $n=189)$, and with fens excluded $(n=89)$. Strong correlations are in bold.

\begin{tabular}{lrr} 
& PctWet & PctWet \\
& All & No fens \\
\hline TotalSpp & $\mathbf{- 0 . 5 9}$ & $\mathbf{- 0 . 5 5}$ \\
NativeSppTotal & $\mathbf{- 0 . 5 0}$ & -0.42 \\
ExoticSppTotal & $\mathbf{- 0 . 6 6}$ & $\mathbf{- 0 . 6 5}$ \\
AvgCovNativeGrams & 0.17 & -0.12 \\
MeanCAll & $\mathbf{0 . 5 5}$ & $\mathbf{0 . 5 8}$ \\
MeanCNative & 0.44 & 0.46 \\
CovWMeanC & $\mathbf{0 . 5 9}$ & $\mathbf{0 . 6 3}$ \\
CovWMeanCNative & 0.43 & 0.39 \\
FQIAll & -0.18 & -0.08 \\
FQINative & -0.27 & -0.20 \\
CWFQIAll & -0.07 & 0.03 \\
CWFQINative & -0.17 & -0.11 \\
AdjustedFQINative & $\mathbf{0 . 5 1}$ & $\mathbf{0 . 5 2}$ \\
AdjCovWFQINative & 0.41 & 0.31 \\
\hline
\end{tabular}

Correlations between FQAI metrics and the percentage of hydrophytes at a site do not necessarily indicate that wetter sites are "better" than drier sites, or that the presence of water at a given site predicts its FQAI scores. To evaluate relationships between the presence of water and the proportion of hydrophytes, we used descriptive statistics to summarize mean $\mathrm{C}$ by water permanence and by the percentage of standing water in the AA. We expected that sites with widespread standing water or an assignment of "permanent" or "semi-permanent" inundation would have a greater proportion of FACW and OBL species than drier sites, and higher mean C values. Only part of this expectation was borne out by the data. While there appears to be a clear relationship between the percent of standing water and proportion of FACW and OBL species, there does not appear to be any linear relationship between the percent of standing water and Mean C, except for the driest sites (Table 26).

Table 26. Mean $C$ and proportion of FACW and $O B L$ species by percentage of standing water in the AA.

\begin{tabular}{lrrrr}
\hline & \multicolumn{2}{c}{ All sites } & \multicolumn{3}{c}{ All sites, no fens } \\
\cline { 2 - 5 } AAWater & Mean C & Pct Wet & Mean C & Pct Wet \\
\hline $1-25 \%$ & 5.16 & 61.32 & 4.51 & 46.21 \\
$26-50 \%$ & 4.90 & 57.75 & 4.38 & 42.56 \\
$51-75 \%$ & 5.01 & 70.20 & 4.87 & 70.85 \\
$76-100 \%$ & 5.42 & 77.41 & 4.64 & 69.90 \\
none & 4.54 & 53.83 & 3.81 & 47.59 \\
\hline
\end{tabular}




\section{DISCUSSION}

Wetlands are abundant in this study area compared to other parts of the state, largely because of the sizeable snowpack that forms during winter months. They also tend to exhibit more ecological integrity than do wetlands in eastern and southwestern Montana, and to be subject to fewer stressors. We attribute this to several factors. First, most of the areas sampled are in public ownership, where steep terrain, difficult or no road access and a harsh climate limit public use. Second, the climate promotes lush vegetation growth, so that even though exotic species colonize disturbed areas such as logging sites, they have more difficulty establishing in sites that are already vegetated. Third, the wetlands are more abundant. Even in areas where livestock range freely, the sheer number of wetlands appears to spread out the disturbance, in contrast to what we sometimes see in eastern Montana, where water scarcity tends to concentrate impacts near wetlands.

Private land access continues to be a challenge in aquatic resource monitoring (Leibowitz et al. 1991, Fellows and Buhl 1995, Adamus et al. 2001). Only $7 \%$ of the sites surveyed in the field were privately owned, despite our randomized sampling approach, because we were repeatedly denied access. In our analysis of Human Disturbance Index (HDI) scores, we saw that wetlands on private land tend to have a greater number of stressors within their buffer area, but lack of access prevented us from evaluating this result in the field. Therefore, conclusions drawn from our Level 2 and Level 3 surveys should be taken as indicating the condition of wetlands on public land, rather than all wetlands in the study area subbasins. And indeed, because our sampling was, of necessity, limited to sites within close enough proximity to roads that they could be accessed by crews, the overall condition of public land wetlands may be even better than reported.

In previous studies, we observed poor correlations between FQA metrics and wetland condition as reflected in Level 2 attribute scores (McIntyre et al. 2011, Newlon and Vance 2011, Newlon 2012). Here, we found stronger (although still moderate) correlations. This suggests that wetland plant species in our study area are adapted to a narrower range of climatic conditions and disturbance regimes, and thus are less tolerant to disturbance than their counterparts in other parts of the state. However, we note that FQA metrics may covary with both environmental variation and anthropogenic disturbances, limiting the utility of these metrics in assessing wetland condition (Wilcox et al. 2002, Euliss and Mushet 2011).

In this study area, we saw little correlation between Mean $\mathrm{C}$ and the proportion of wetland plants at a site, while in the larger group of sites assessed over the past few years, the correlation was present. We surmise that this is due, in part, to the relatively high Mean $\mathrm{C}$ observed in the Blackfoot-Swan project area, and the general conditions which support hydrophytic plants. We also believe that regional variation may play out in other conclusions. For example, analyzing the larger data set, we found that while there appears to be a clear relationship between the percent of standing water and proportion of FACW and OBL species, there does not appear to be any linear relationship between the percent of standing water and Mean C, except at the driest sites. Because of differences in database structures, our analysis was limited to sites assessed during our most recent rotating basin studies, which meant that sites from the northern Glaciated Plains, 
and particularly the Prairie Pothole region, were not included. Due to the fluctuating water regimes experienced by wetlands in that region, we suspect that we would see different results there, but this will require empirical investigation before we can draw conclusions.

Finally, based on our field observations, we were satisfied with our identification of Intermontane Prairie Potholes as a new Ecological System in the glaciated valleys of northern Montana. While it is similar to several marsh systems - notably the Boreal Freshwater Emergent Marsh and the North-Central Interior Freshwater Marsh found in southern Canada and the U.S. Midwest - we feel that the grassland matrix in which it occurs distinguishes it from these other glacial pothole systems, which are typically found in more woody environments. More research will be necessary to determine if the potholes which have been casually observed on benches and toe slopes in the mountains are examples of this system, one of the marsh systems, or some other system altogether. 


\section{LITERATURE CITED}

Adamus, P. R., T. J. Danielson, and A. Gonyaw. 2001. Indicators of monitoring biological integrity of inland freshwater wetlands: a survey of North American Technical Literature (1990-2000). Office of Wetlands, Oceans, and Watersheds, U.S. Environmental Protection Agency, Washington, D.C. EPA-843-R-01.

Andreas, B. K., J. J. Mack, and J. S. McCormac. 2004. Floristic quality assessment index (FQAI) for vascular plants and mosses for the State of Ohio. Ohio Environmental Protection Agency, Division of Surface Water, Wetland Ecology Group, Columbus, Ohio.

Brinson, M. M. 1993. A hydrogeomorphic classification for wetlands. Technical Report WRPDE-4, Waterways Experiment Station, Army Corps of Engineers, Vicksburg, Mississippi.

California Wetlands Monitoring Workgroup (CWMW). 2013. California Rapid Assessment Method (CRAM) for Wetlands, version 6.1.

Comer, P., D. Faber-Langendoen, R. Evans, S. Gawler, C. Josse, G. Kittel, S. Menard, M. Pyne, M. Reid, K. Schulz, K. Snow, and J. Teague. 2003. Ecological Systems of the United States: A Working Classification of U.S. Terrestrial Systems. NatureServe, Arlington, VA.

Cowardin, L. M., V. Carter, F. C. Golet, and E. T. LaRoe. 1979. Classification of wetlands and deepwater habitats of the United States. U.S. Fish and Wildlife Service, Washington, D.C. FWS/OBS-79/31.

Cronk, J. K., and M. S. Fennessy. 2001. Wetlands plants: biology and ecology. CRC Press, Boca Raton, FL.

Euliss, N. H., Jr., and D. M. Mushet. 2011. A multi-year comparison of IPCI scores for prairie pothole wetlands: implications of temporal and spatial variation. Wetlands. Advanced online publication. DOI: 10.1007/s13157-011-0187-2.

Faber-Langendoen, D., C. Hedge, M. Kost, S. Thomas, L. Smart, R. Smyth, J. Drake, and S. Menard. 2011. Assessment of wetland ecosystem condition across landscape regions: a multi-metric approach. NatureServe, Arlington, VA. + Appendices.

Fellows, D. P., and T. K. Buhl. 1995. Research access to privately owned wetland basins in the Prairie Pothole Region of the United States. Wetlands 15:330-335.

Grossman, D. H., D. Faber-Langendoen, A. S. Weakley, M. Anderson, P. Bourgeron, R. Crawford, K. Goodin, S. Landaal, K. Metzler, K. D. Patterson, M. Pyne, M. Reid, and L. Sneddon. 1998. International classification of ecological communities: terrestrial vegetation of the United States. Volume I. The National Vegetation Classification 
System: development, status, and applications. The Nature Conservancy, Arlington, Virginia, USA.

Hauer, F. R., B. J. Cook, M. C. Gilbert, E. J. Clairain, Jr., and R. D. Smith. 2002. A regional guidebook for applying the hydrogeomorphic approach to assessing wetland functions of intermontane prairie pothole wetlands in the northern Rocky Mountains. ERDC/EL TR02-7.

Herman, K. D., L. A. Masters, M. R. Penskar, A. A. Reznicek, G. S. Wilhelm, and W. W. Brodowicz. 1997. Floristic quality assessment: development and application in the State of Michigan (USA). Natural Areas Journal 17:256-279.

Johnson, B. 2005. Hydrogeomorphic wetland profiling: an approach to landscape and cumulative impacts analysis. EPA/620/R05/001. U.S. Environmental Protection Agency, Washington, D.C.

Kincaid, T., and T. Olsen. 2009. spsurvey: Spatial survey design and analysis. R package version 2.1.

Lemly, J. L., and J. Rocchio. 2009. Vegetation index of biotic integrity (VIBI) for headwater wetlands in the southern Rocky Mountains. Version 2.0: Calibration of selected VIBI models. Colorado Natural Heritage Program.

Leibowitz, N., L. Squires, and J. Baker. 1991. Research plan for monitoring wetland ecosystems. EPA/600/3-91/010. US Environmental Protection Agency, Environmental Research Laboratory, Corvallis, Oregon 157 pp plus appendices.

Lesica, P. 2012. Manual of Montana Vascular Plants. BRIT Press, Fort Worth, TX.

Lesica, P. 1994. The distribution of plant community diversity associated with glacial wetlands in the Ovando Valley, Montana. Report to The Nature Conservancy, Montana Field Office.

Lichvar, R.W., M. Butterwick, N.C. Melvin, and W.N. Kirchner. 2014. The National Wetland Plant List: 2014 Update of Wetland Ratings. Phytoneuron 2014-41: 1-42.

Mack, J. J. 2001. Ohio Rapid Assessment Method for Wetlands, manual for using version 5.0. Ohio EPA Technical Bulletin Wetland/2001-1-1. Ohio Environmental Protection Agency, Division of Surface Water, 401 Wetland Ecology Unit, Columbus, Ohio.

Mack, J. J. 2004. Integrated Wetland Assessment Program. Part 4: Vegetation Index of Biotic Integrity (VIBI) and Tiered Aquatic Life Uses (TALUs) for Ohio wetlands. Ohio EPA Technical Report WET/2004-4. Ohio Environmental Protection Agency, Wetland Ecology Group, Division of Surface Water, Columbus, Ohio. 
McIntyre, C., K. R. Newlon, L. K.Vance, and M. D. Burns. 2011. Milk, Marias, and St. Mary monitoring: developing a long-term rotating basin wetland assessment and monitoring strategy for Montana. Helena, Montana: Montana Natural Heritage Program.

Miller, S. J., and D. H. Wardrop. 2006. Adapting a floristic quality assessment index to indicate anthropogenic disturbance in central Pennsylvania wetlands. Ecological Indicators 6:313-326.

Montana Natural Heritage Program (MTNHP). 2002 List of Ecological Communities for Montana. http://mtnhp.org/docs/Community_list_2002.pdf

Montana Natural Heritage Program (MTNHP). 2013. Montana Land Cover/Land Use Theme. Based on classifications originally developed by the University of Idaho, Sanborn and the MTNHP for the Pacific Northwest ReGAP project. Helena, Montana.

Montana Natural Heritage Program (MTNHP). 2014. Montana Ecological Integrity Assessment Field Manual. Now replaced by 2015 version at http://mtnhp.org/wetlands/docs/EIAProtocol_2015.pdf

Montana Natural Heritage Program (MTNHP). 2015 C-value spreadsheet. Available from http://mtnhp.org/plants/

Munsell Color Company. 2000. Munsell Soil Color Charts. Revised washable edition. New Windsor, Gretag Macbeth.

NatureServe. In preparation. Draft National Vegetation Classification Standard. Arlington, VA.

Newlon, Karen R. 2012. Southwest Montana Wetland Assessment: Developing a statewide assessment and monitoring strategy for Montana. Report to the U.S. Environmental Protection Agency. Montana Natural Heritage Program, Helena, Montana. 39 pp. plus appendices.

Newlon, K. R. 2015. Montana Human Disturbance Index. Available from http://mslapps.mt.gov/Geographic_Information/Data/DataList/datalist_Details?did=\{639 e7c86-8224-11e4-b116-123b93f75cba\}

Newlon, K. R., and L. K. Vance. 2011. A reference wetland network for assessment and monitoring of Montana's herbaceous wetlands. Report to the U.S. Environmental Protection Agency. Montana Natural Heritage Program, Helena, Montana. 23 pp. plus appendices.

Omernik, J. M. 1987. Ecoregions of the conterminous United States. Map (scale 1:7,500,00). Annals of the Association of American Geographers 77:118-125.

Peet, R.K., T.R. Wentworth, and P.S. White. 1998. A flexible, multipurpose method for recording vegetation composition and structure. Castanea 63: 262-274. 
R Development Core Team. 2009. R: A language and environment for statistical computing. R Foundation for Statistical Computing, Vienna, Austria. ISBN 3-900051-07-0, URL http://www.R-project.org.

Rocchio, J. 2006. Vegetation index of biotic integrity for Southern Rocky Mountain fens, wet meadows, and riparian shrublands: phase 1 final report. Unpublished report prepared for the Colorado Department of Natural Resources and US EPA Region 8. Colorado Natural Heritage Program, Colorado State University, Fort Collins, Colorado.

Rocchio, J. 2007. Assessing ecological condition of headwater wetlands in the Southern Rocky Mountains using a vegetation index of biotic integrity. (Version 1.0). Unpublished report prepared for the Colorado Department of Natural Resources and US EPA Region 8.

Colorado Natural Heritage Program, Colorado State University, Fort Collins, Colorado.

Stevens, D.L., Jr., and A.R. Olsen. 2004. Spatially balanced sampling of natural resources. Journal of American Statistical Association 99:262-278.

Stevens, D. L. Jr., and S. F. Jensen. 2007. Sample design, execution, and analysis for wetland assessment. Wetlands 27:515-523.

Sutula, M. A., E. D. Stein, J. N. Collins, A. E. Fetscher, and R. Clark. 2006. A practical guide for the development of a wetland assessment method: the California experience. Journal of the American Water Resources Association 42:157-175.

U.S. Army Corps of Engineers. 2010. Regional supplement to the Corps of Engineers Wetland Delineation Manual: western mountains, valleys, and coast region (Version 2.0), J.S. Wakeley, R. W. Lichvar, and C. V. Noble (eds.). ERDC.EL TR-10-3. Vicksburg, Mississippi: U.S. Army Engineer Research and Development Center.

Western Regional Climate Center. 2015. Cooperative Climatological Data Summaries. NOAA Cooperative Stations - Temperature and Precipitation. http://wrcc.dri.edu/climatedata/climsum/, accessed 1 September 2015.

Wilcox, D. A., J. E. Meeker, P. L. Hudson, B. J. Armitage, M. G. Black, and D. G. Uzarski. 2002. Hydrologic variability and the application of the index of biotic integrity metrics to wetlands: a Great Lakes evaluation. Wetlands 22:588-615. 
Appendix A. National Wetland Inventory (NWI) attribute codes included in the Blackfoot-Swan Intensification Project wetland assessment sample frame.

\begin{tabular}{|c|c|c|c|c|}
\hline Attribute & System & Class & Regime & Modifier \\
\hline PABF & Palustrine & Aquatic Bed & Semipermanently Flooded & \\
\hline $\mathrm{PABFb}$ & Palustrine & Aquatic Bed & Semipermanently Flooded & Beaver \\
\hline PABFh & Palustrine & Aquatic Bed & Semipermanently Flooded & Diked/Impounded \\
\hline PABFx & Palustrine & Aquatic Bed & Semipermanently Flooded & Excavated \\
\hline PABG & Palustrine & Aquatic Bed & Intermittently Exposed & \\
\hline PABGb & Palustrine & Aquatic Bed & Intermittently Exposed & Beaver \\
\hline PABGh & Palustrine & Aquatic Bed & Intermittently Exposed & Diked/Impounded \\
\hline PEMA & Palustrine & Emergent & Temporarily Flooded & \\
\hline PEMAd & Palustrine & Emergent & Temporarily Flooded & Partially Drained/Ditched \\
\hline PEMAh & Palustrine & Emergent & Temporarily Flooded & Diked/Impounded \\
\hline PEMAx & Palustrine & Emergent & Temporarily Flooded & Excavated \\
\hline PEMB & Palustrine & Emergent & Saturated & \\
\hline PEMBb & Palustrine & Emergent & Saturated & Beaver \\
\hline PEMC & Palustrine & Emergent & Seasonally Flooded & \\
\hline PEMCh & Palustrine & Emergent & Seasonally Flooded & Diked/Impounded \\
\hline PEMCx & Palustrine & Emergent & Seasonally Flooded & Excavated \\
\hline PEMF & Palustrine & Emergent & Semipermanently Flooded & \\
\hline PEMFh & Palustrine & Emergent & Semipermanently Flooded & Diked/Impounded \\
\hline PEMFx & Palustrine & Emergent & Semipermanently Flooded & Excavated \\
\hline PFOA & Palustrine & Forested & Temporarily Flooded & \\
\hline PFOAh & Palustrine & Forested & Temporarily Flooded & Diked/Impounded \\
\hline PFOAx & Palustrine & Forested & Temporarily Flooded & Excavated \\
\hline PFOB & Palustrine & Forested & Saturated & \\
\hline $\mathrm{PFOBb}$ & Palustrine & Forested & Saturated & Beaver \\
\hline PSSA & Palustrine & Scrub-Shrub & Temporarily Flooded & \\
\hline PSSAh & Palustrine & Scrub-Shrub & Temporarily Flooded & Diked/Impounded \\
\hline PSSAx & Palustrine & Scrub-Shrub & Temporarily Flooded & Excavated \\
\hline PSSB & Palustrine & Scrub-Shrub & Saturated & \\
\hline PSSBb & Palustrine & Scrub-Shrub & Saturated & Beaver \\
\hline PSSBd & Palustrine & Scrub-Shrub & Saturated & Partially Drained/Ditched \\
\hline PSSC & Palustrine & Scrub-Shrub & Seasonally Flooded & \\
\hline PSSCh & Palustrine & Scrub-Shrub & Seasonally Flooded & Diked/Impounded \\
\hline
\end{tabular}




\begin{tabular}{|c|c|c|c|c|}
\hline Attribute & System & Class & Regime & Modifier \\
\hline PABKx & Palustrine & Aquatic Bed & Artificially Flooded & Excavated \\
\hline PUBF & Palustrine & Unconsolidated Bottom & Semipermanently Flooded & \\
\hline PUBFx & Palustrine & Unconsolidated Bottom & Semipermanently Flooded & Excavated \\
\hline PUBG & Palustrine & Unconsolidated Bottom & Intermittently Exposed & \\
\hline PUSA & Palustrine & Unconsolidated Shore & Temporarily Flooded & \\
\hline PUSAh & Palustrine & Unconsolidated Shore & Temporarily Flooded & Diked/Impounded \\
\hline PUSAx & Palustrine & Unconsolidated Shore & Temporarily Flooded & Excavated \\
\hline PUSC & Palustrine & Unconsolidated Shore & Seasonally Flooded & \\
\hline PUSCd & Palustrine & Unconsolidated Shore & Seasonally Flooded & Partially Drained/Ditched \\
\hline PUSCh & Palustrine & Unconsolidated Shore & Seasonally Flooded & Diked/Impounded \\
\hline PUSCx & Palustrine & Unconsolidated Shore & Seasonally Flooded & Excavated \\
\hline
\end{tabular}


Appendix C. Lacustrine and riverine National Wetland Inventory (NWI) attribute codes excluded from the Blackfoot-Swan Intensification Project wetland assessment sample frame.

\begin{tabular}{|c|c|c|c|c|c|}
\hline Attribute & System & Subsystem & Class & Regime & Modifier \\
\hline L1UBG & Lacustrine & Limnetic & Unconsolidated Bottom & Intermittently Exposed & \\
\hline L1UBH & Lacustrine & Limnetic & Unconsolidated Bottom & Permanently Flooded & \\
\hline L1UBHh & Lacustrine & Limnetic & Unconsolidated Bottom & Permanently Flooded & Diked/Impounded \\
\hline $\mathrm{L} 2 \mathrm{ABF}$ & Lacustrine & Littoral & Aquatic Bed & Semipermanently Flooded & \\
\hline $\mathrm{L} 2 \mathrm{ABFh}$ & Lacustrine & Littoral & Aquatic Bed & Semipermanently Flooded & Diked/Impounded \\
\hline $\mathrm{L} 2 \mathrm{ABG}$ & Lacustrine & Littoral & Aquatic Bed & Intermittently Exposed & \\
\hline L2ABGh & Lacustrine & Littoral & Aquatic Bed & Intermittently Exposed & Diked/Impounded \\
\hline L2UBF & Lacustrine & Littoral & Unconsolidated Bottom & Semipermanently Flooded & \\
\hline L2UBG & Lacustrine & Littoral & Unconsolidated Bottom & Intermittently Exposed & \\
\hline L2USA & Lacustrine & Littoral & Unconsolidated Shore & Temporarily Flooded & \\
\hline L2USAh & Lacustrine & Littoral & Unconsolidated Shore & Temporarily Flooded & Diked/Impounded \\
\hline L2USC & Lacustrine & Littoral & Unconsolidated Shore & Seasonally Flooded & \\
\hline L2USCh & Lacustrine & Littoral & Unconsolidated Shore & Seasonally Flooded & Diked/Impounded \\
\hline R2UBG & Riverine & Lower Perennial & Unconsolidated Bottom & Intermittently Exposed & \\
\hline R2UBH & Riverine & Lower Perennial & Unconsolidated Bottom & Seasonally Flooded & \\
\hline R2USA & Riverine & Lower Perennial & Unconsolidated Shore & Temporarily Flooded & \\
\hline R3UBF & Riverine & Upper Perennial & Unconsolidated Bottom & Semipermanently Flooded & \\
\hline R3UBFx & Riverine & Upper Perennial & Unconsolidated Bottom & Semipermanently Flooded & Excavated \\
\hline R3UBG & Riverine & Upper Perennial & Unconsolidated Bottom & Intermittently Exposed & \\
\hline R3UBH & Riverine & Upper Perennial & Unconsolidated Bottom & Seasonally Flooded & \\
\hline R3USA & Riverine & Upper Perennial & Unconsolidated Shore & Temporarily Flooded & \\
\hline R3USC & Riverine & Upper Perennial & Unconsolidated Shore & Seasonally Flooded & \\
\hline R4SBA & Riverine & Intermittent & Streambed & Temporarily Flooded & \\
\hline R4SBC & Riverine & Intermittent & Streambed & Seasonally Flooded & \\
\hline R4SBCx & Riverine & Intermittent & Streambed & Seasonally Flooded & Excavated \\
\hline R4USA & Riverine & Intermittent & Unconsolidated Shore & Temporarily Flooded & \\
\hline
\end{tabular}


Appendix D. Scoring procedure for calculating stressor impact ratings (sensu FaberLangendoen et al. 2011).

Table 1. Stressor impact ratings calculations.

\begin{tabular}{llllllll}
\hline & & \multicolumn{7}{c}{ Scope } \\
\hline \multirow{1}{*}{ Severity } & Extreme & Pervasive & Large & Restricted & Moderate & Small & Nil \\
& Serious & High & High & Medium & Medium & Low & Low \\
& Moderate & Medium & Medium & Low & Low & Low & Low \\
& Slight & Low & Low & Low & Low & Low & Low \\
\hline
\end{tabular}

Table 2. Stressor impact rating numerical conversions.

\begin{tabular}{|c|c|c|c|c|c|c|c|}
\hline & & \multicolumn{6}{|c|}{ Scope } \\
\hline \multirow{5}{*}{ Severity } & & 5 & 4 & 3 & 2 & 1 & 0 \\
\hline & 4 & 20 & 16 & 12 & 8 & 4 & 0 \\
\hline & 3 & 15 & 12 & 9 & 6 & 3 & 0 \\
\hline & 2 & 10 & 8 & 6 & 4 & 2 & 0 \\
\hline & 1 & 5 & 4 & 3 & 2 & 1 & 0 \\
\hline
\end{tabular}

Table 3. Rollup procedure for calculating an overall stressor impact rating.

\begin{tabular}{ll}
\hline Impact Values of Stressor Categories & Overall Stressor Rating \\
\hline 1 or more Very High Stressors, OR 2 or more & \\
High, OR 1 High + 2 or more Medium & Very High (1) \\
$\begin{array}{l}\text { 1 High Stressor, OR } 3 \text { or more Medium, OR 2 } \\
\text { Medium + 2 or more Low, OR 1 Medium, + 3 or } \\
\text { more Low }\end{array}$ & \\
$\begin{array}{l}1 \text { Medium Stressor + 5 or more Low, OR 8 or } \\
\text { more Low }\end{array}$ & Medium (2) \\
$\begin{array}{l}1 \text { Medium Stressor + 1-4 Low, OR 1-7 Low } \\
\text { Stressors }\end{array}$ & Low (4) \\
0 Stressors & Absent (0) \\
\hline
\end{tabular}




\section{Appendix E. Scoring formulas for Level 2 attribute and overall wetland condition scores.}

1. For each metric, convert narrative rating score (1, 2, 3, 4, and 5) into the corresponding metric score: $1=12,2=9,3=6,4=3$, and $5=1$.If metric has only four narrative ratings, then $1=12,2=9$, $3=6,4=3$. If metric had only three narrative ratings, then $1=12,2=6$, and $3=1$.

2. Each final attribute score was calculated according to the following:

$\underline{\text { Landscape Context (LC) Attribute Score: }}$

Raw score $=[(($ Buffer Condition_Plants + Buffer Condition_Soils + Buffer

Condition_Trash)/3) $\mathrm{x}$ (Buffer width $\mathrm{x}$ Buffer length $\left.)^{1 / 2}\right]^{1 / 2}+$ Landscape Connectivity

Final Attribute score $=$

Raw Landscape Context Score $\mathrm{x} 100$

Total possible points allowed (24)

Vegetation Attribute Score:

Raw score $=[(($ Invasive native + Native + Noxious $) / 3)+$ Litter or woody debris accumulation + Patch Interspersion $+(($ Woody vegetation $)+$ Browse $) / 2)]$

Final Attribute Score $=$

Raw Biotic Score x 100

Total possible points allowed (48)

Physicochemical Attribute Score:

Raw score $=[$ Soil Surface Integrity $+(($ Water Quality_Algae + Water Quality_Plants + Water Quality_Turbidity)/3)]

Final Attribute Score $=$ Raw Physicochemical Score x 100 Total possible points allowed (24)

Hydrology Attribute Score:

Raw score $=[($ Hydrologic Input + Hydrologic Output $) / 2)+$ Hydroperiod + Surface Water Connectivity scores

Final Attribute Score $=$ Raw Hydrology Score x 100 Total possible points allowed (36)

3. Final AA Score $=$ Final LC + Final Vegetation + Final Physico + Final Hydro/4 
$N_{n}=$ count of native species, $N_{a}=$ count of all species, $N_{e}=$ count of non-native species, $C_{i}=$ index of conservatism for the $i^{\text {th }}$ species, $x_{i}=$ percent cover for the $i^{\text {th }}$ species, $W=$ coefficient of wetness.

\begin{tabular}{lll}
\hline Indices & Description & Calculation
\end{tabular}

Total species richness

Native species richness

Non-native species richness

Cover of native graminoids

Mean C

Mean $\mathrm{C}_{\text {nat }}$

Cover-weighted Mean C

Cover-weighted Mean $\mathrm{C}_{\text {nat }}$

FQI

$\mathrm{FQI}_{\text {nat }}$

Cover-weighted FQI

Cover-weighted FQI ${ }_{\text {nat }}$

Adjusted FQI ${ }_{\text {nat }}$

Adjusted cover-weighted $\mathrm{FQI}_{\text {nat }}$

Wetness Index

Percent of Total Species of at least FAC
Number of plant species observed

Number of native plant species observed

Number of non-native plants

Sum of cover of native graminoids (grasses, sedges, and rushes)

Average C-value of all plants

Average $\mathrm{C}$-value of only the native plants

Sum of each species C-value multiplied by its cover values, then divided by the sum of cover values for all species

Sum of each native species C-value multiplied by its cover values, then divided by the sum of cover values for native species

Mean C of all species multiplied by the squareroot of the number of all plant species

Mean $\mathrm{C}$ of native plant species multiplied by the square-root of the number of native plants

Cover-weighted Mean C for all species multiplied by the square-root of all species

Cover-weighted Mean C for native plants multiplied by the square-root of native plants

Mean $\mathrm{C}$ of native plants divided by 10 multiplied by square-root of native plants divided by the square-root of number of all plants multiplied by 100

Cover-weighted Mean $\mathrm{C}$ for native plants divided by 10 multiplied by square-root of native plants divided by the square-root of number of all plants multiplied by 100

Average coefficient of wetness for native species

Proportion of total species observed that have a wetland indicator status of FAC or wetter 


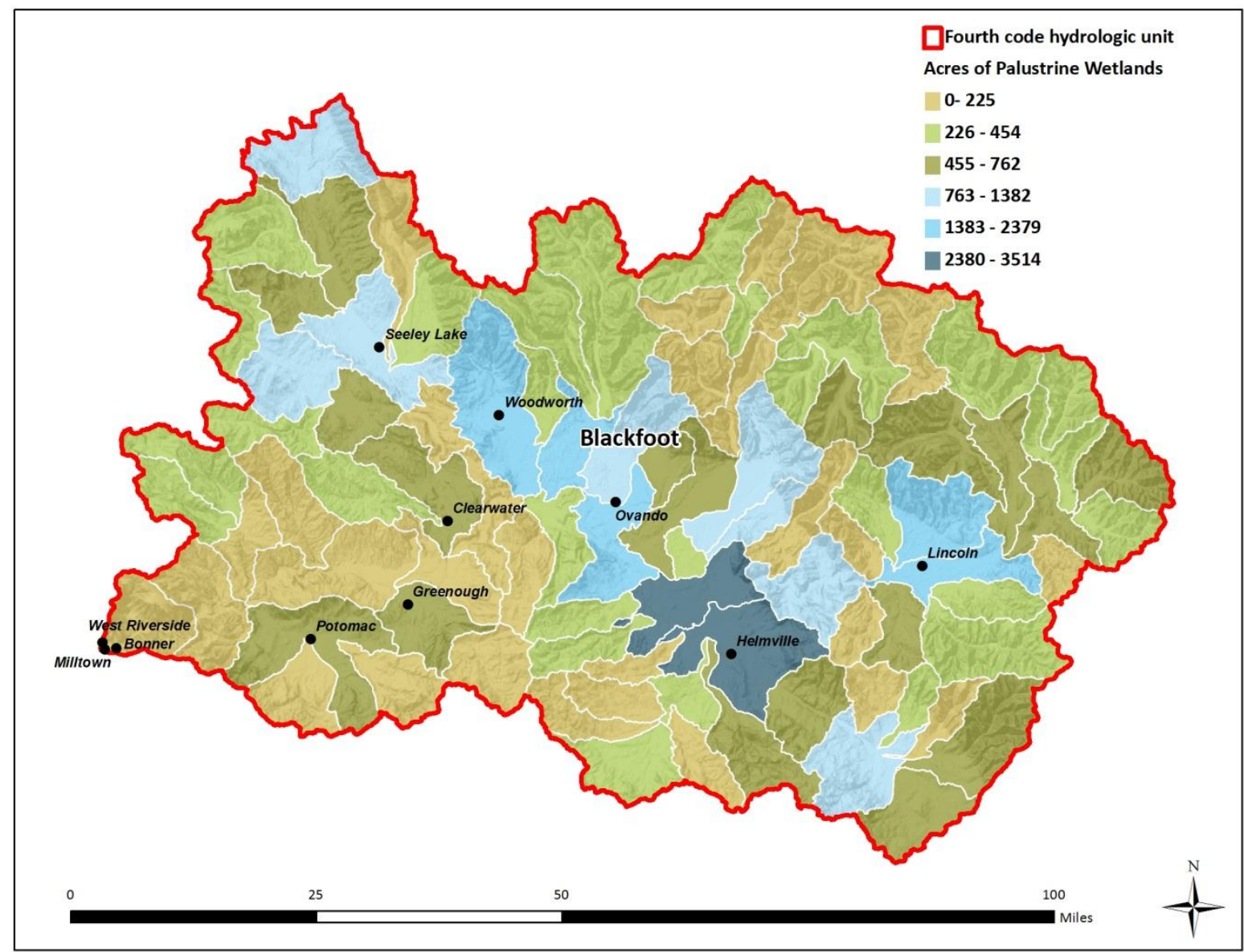

Figure 1. Acres of palustrine wetland by sixth code hydrologic unit in the Blackfoot watershed. 


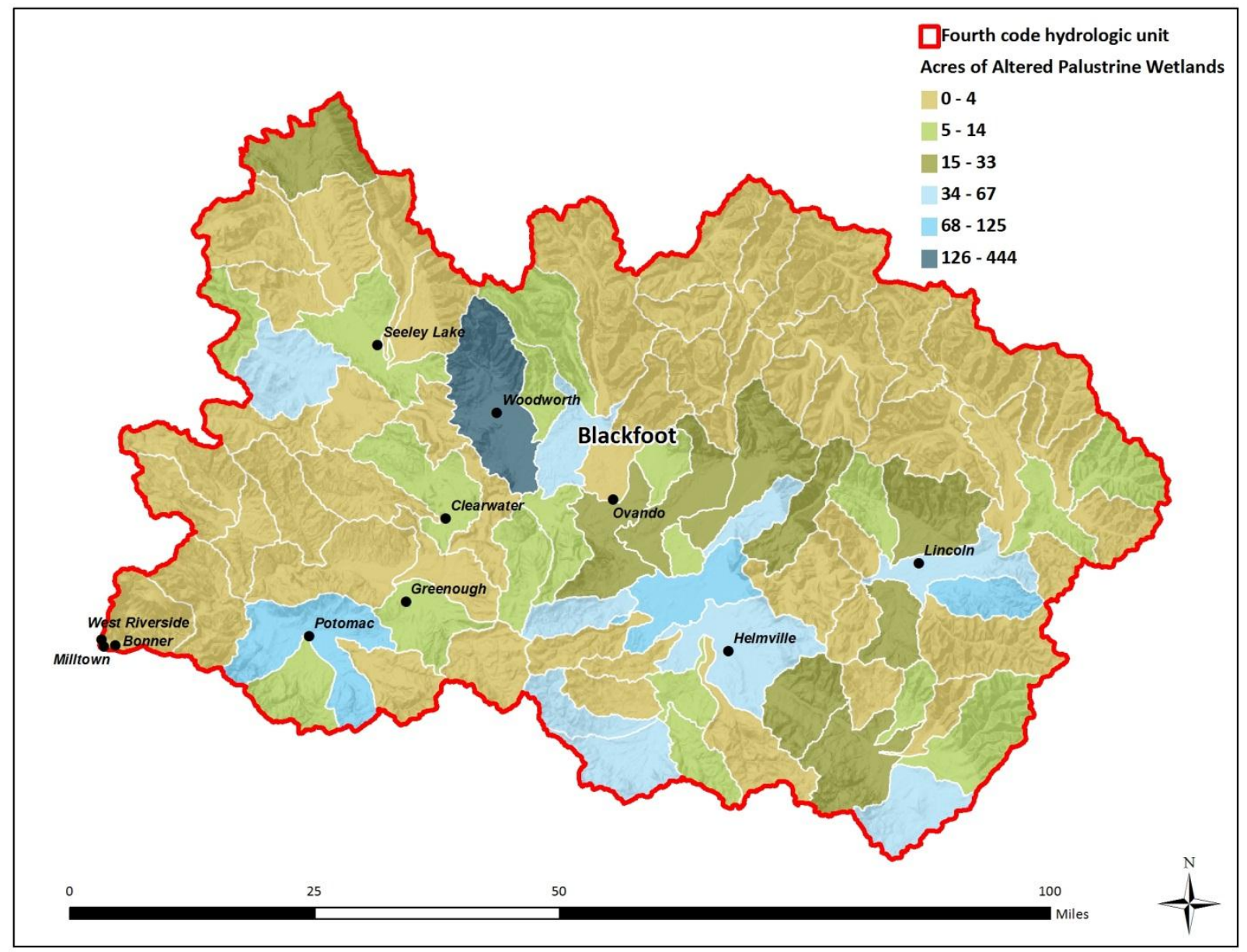

Figure 2. Acres of anthropogenically altered palustrine wetlands (i.e., ditched, drained, impounded, excavated, farmed) by sixth code hydrologic unit in the Blackfoot watershed. 


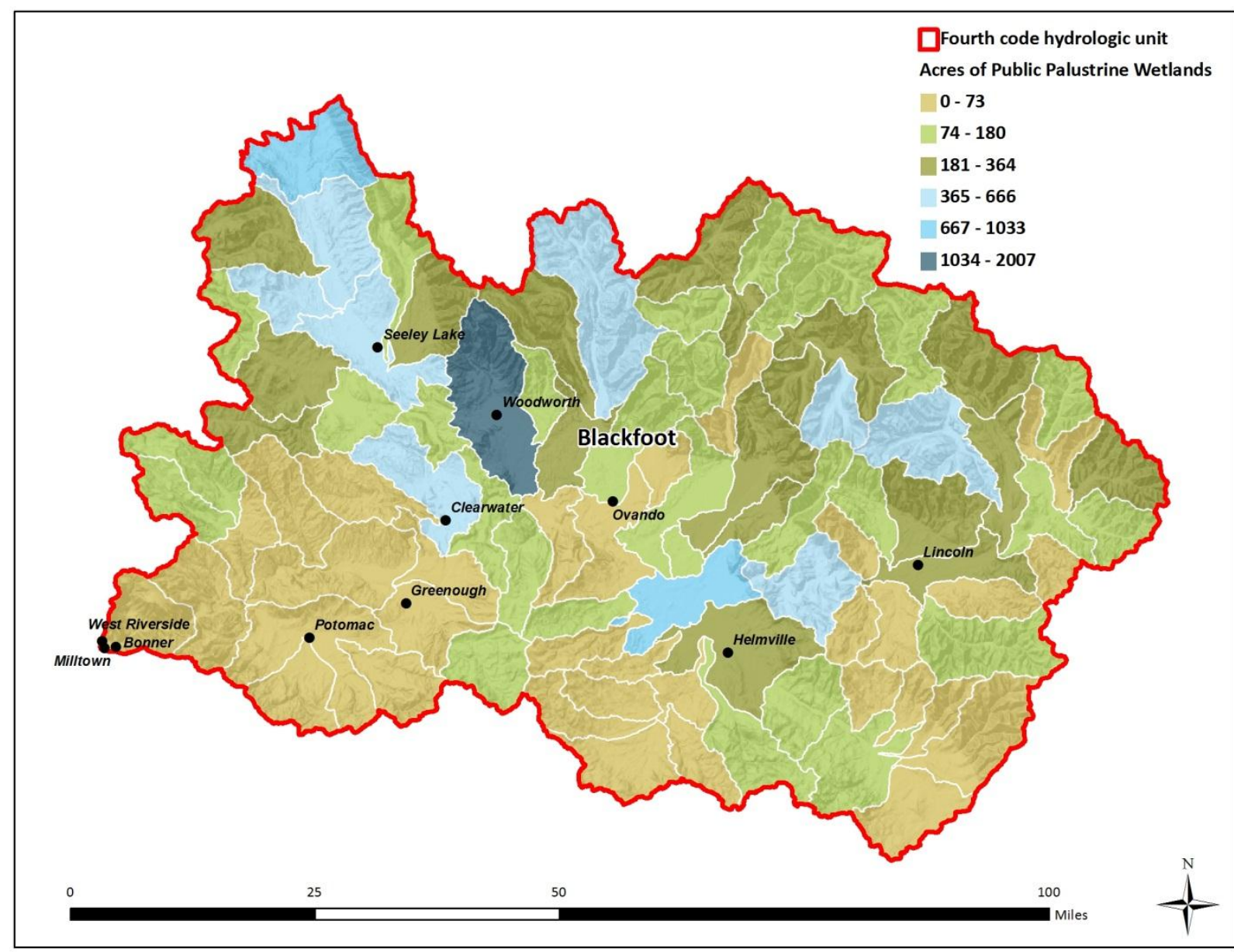

Figure 3. Acres of palustrine wetlands on publicly owned lands by sixth code hydrologic unit in the Blackfoot watershed. 


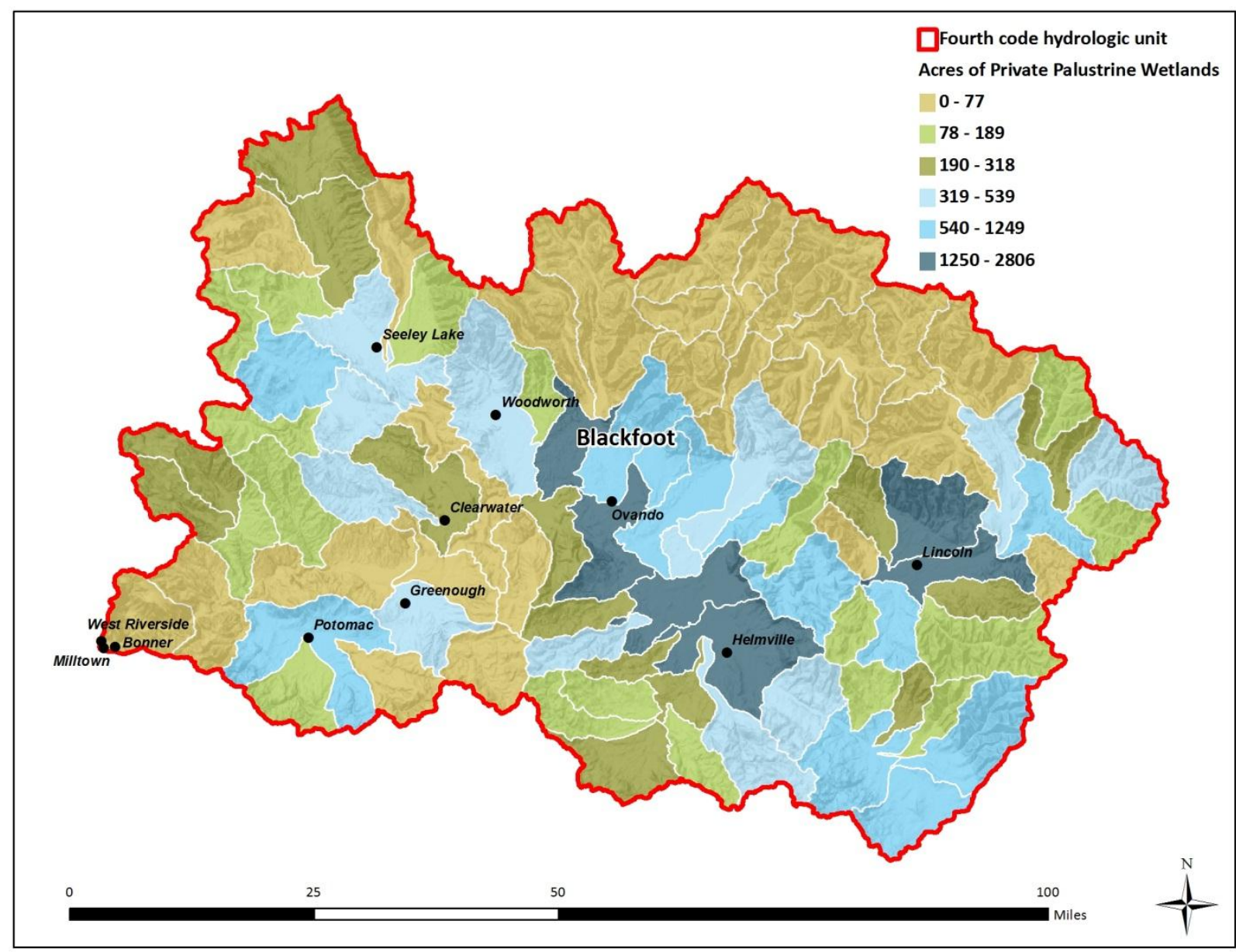

Figure 4. Acres of palustrine wetlands on privately owned lands by sixth code hydrologic unit in the Blackfoot watershed. 


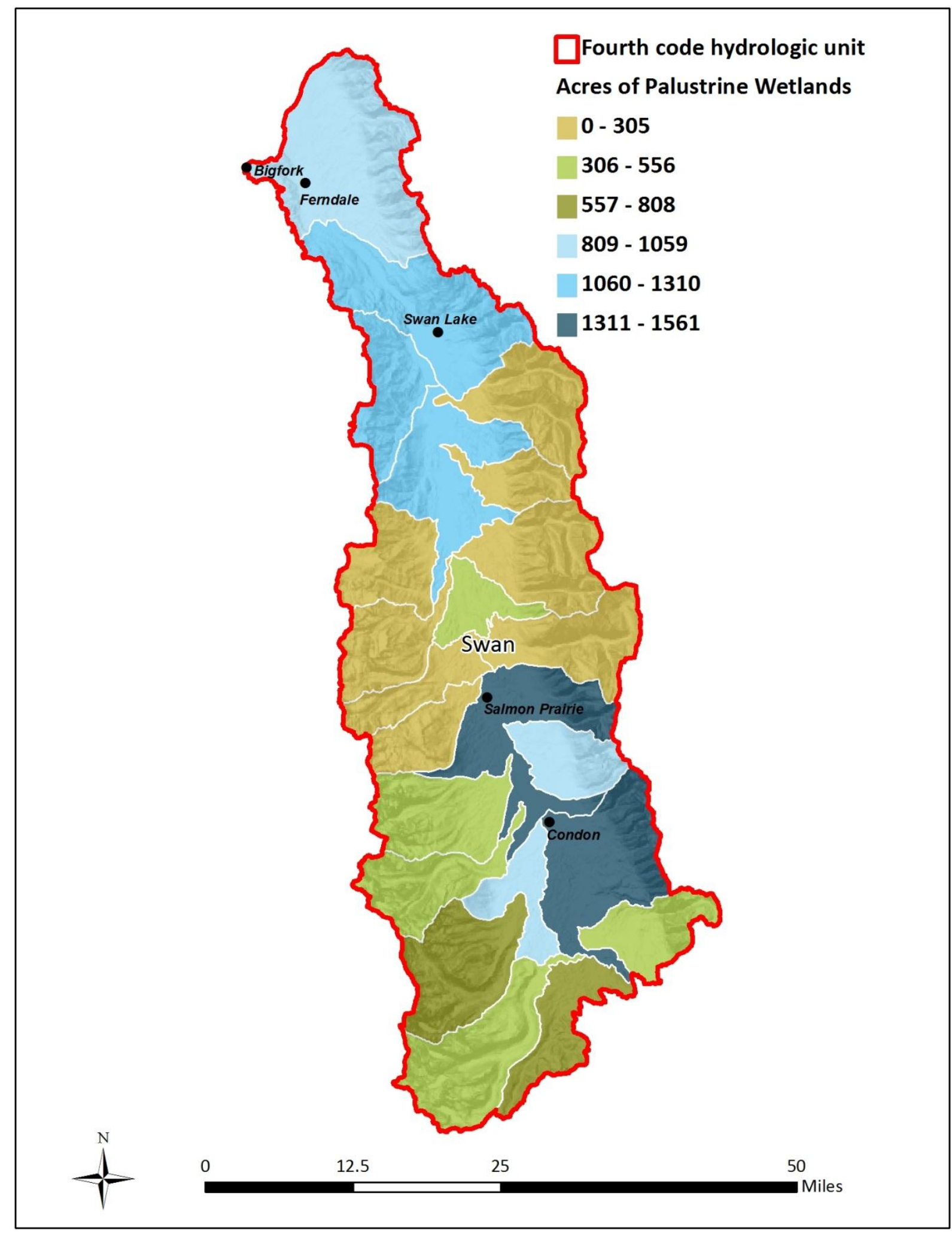

Figure 5. Acres of palustrine wetland by sixth code hydrologic unit in the Swan watershed. 


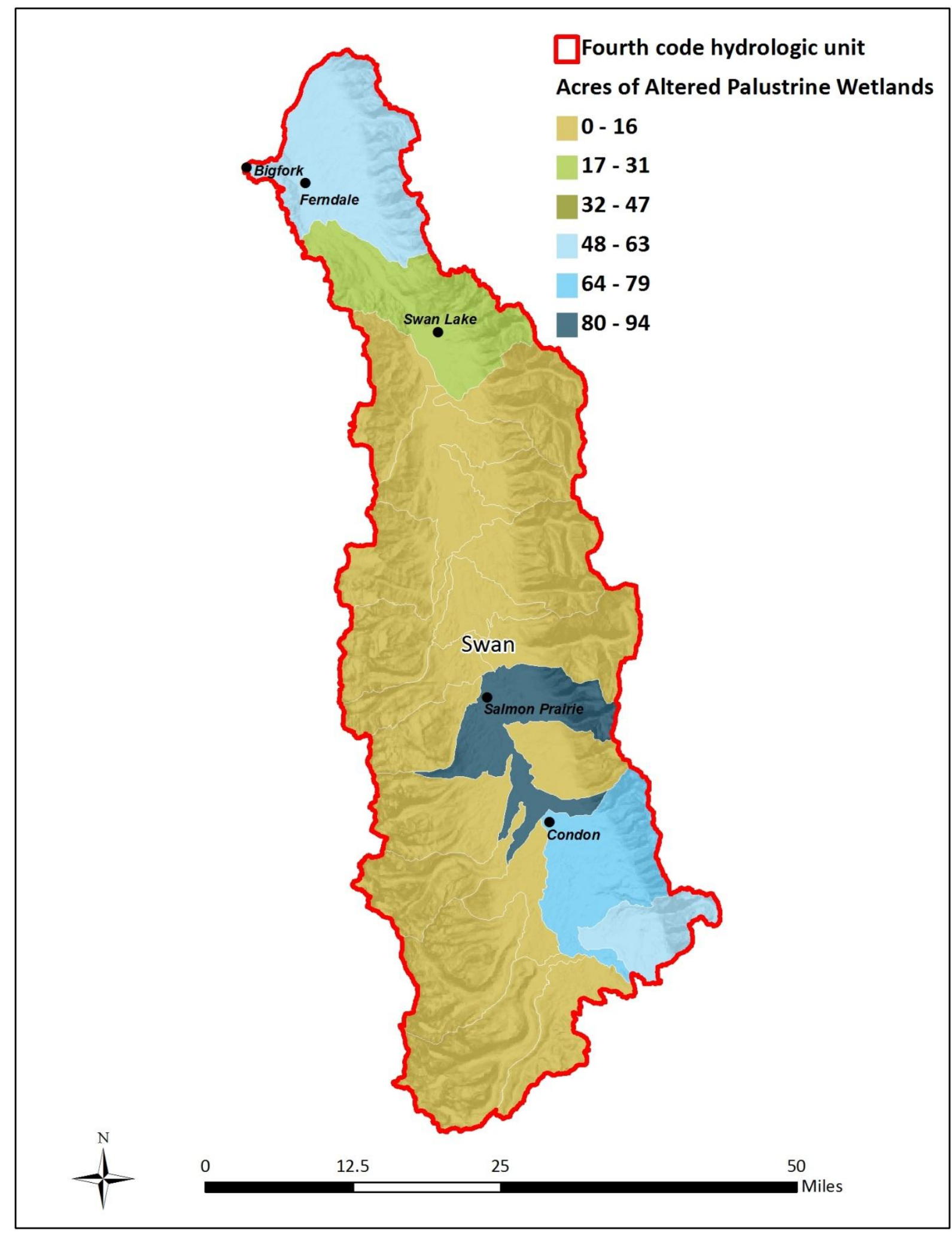

Figure 6. Acres of anthropogenically altered palustrine wetlands (i.e., ditched, drained, impounded, excavated, farmed) by sixth code hydrologic unit in the Swan watershed. 


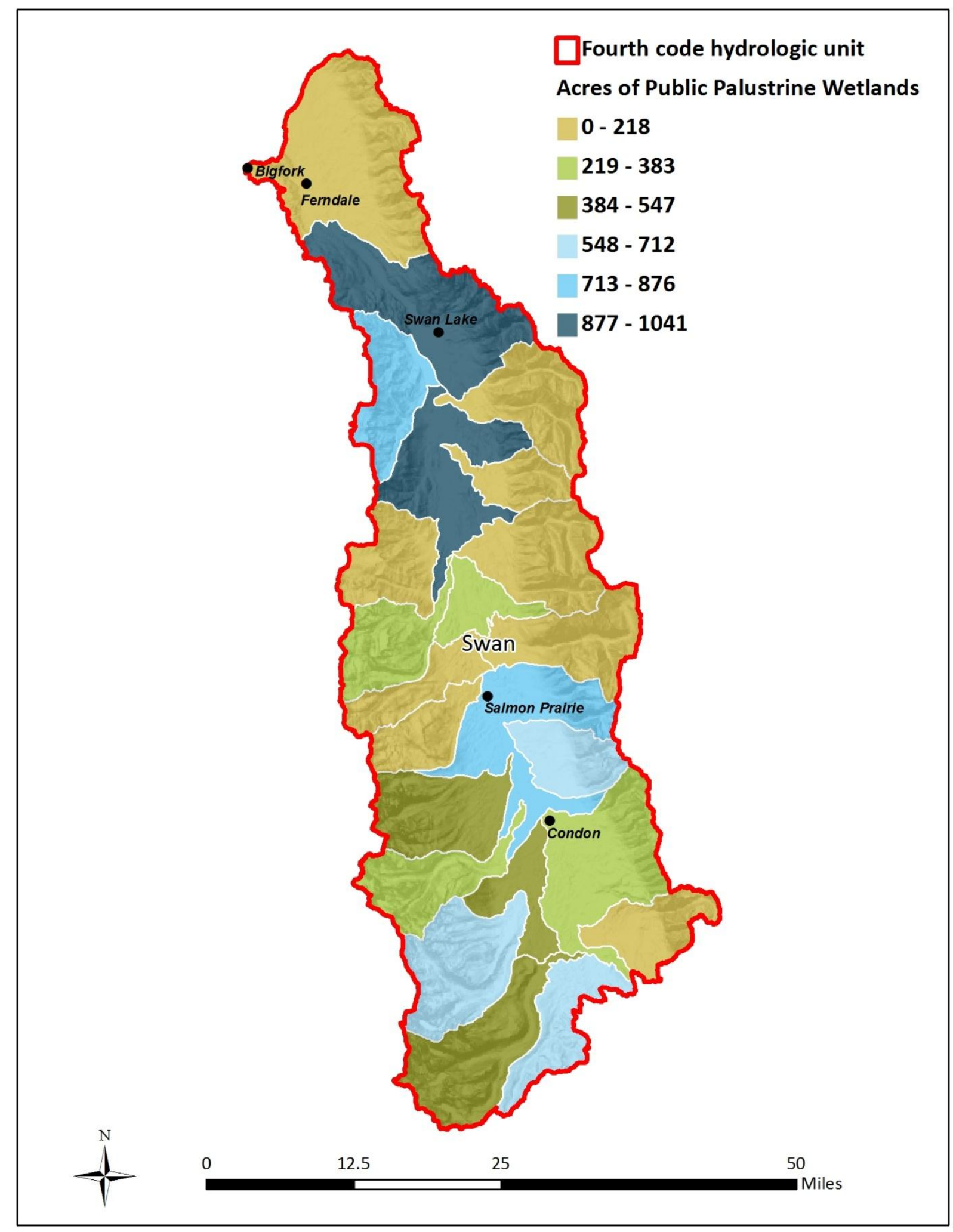

Figure 7. Acres of palustrine wetlands on publicly owned lands by sixth code hydrologic unit in the Swan watershed. 


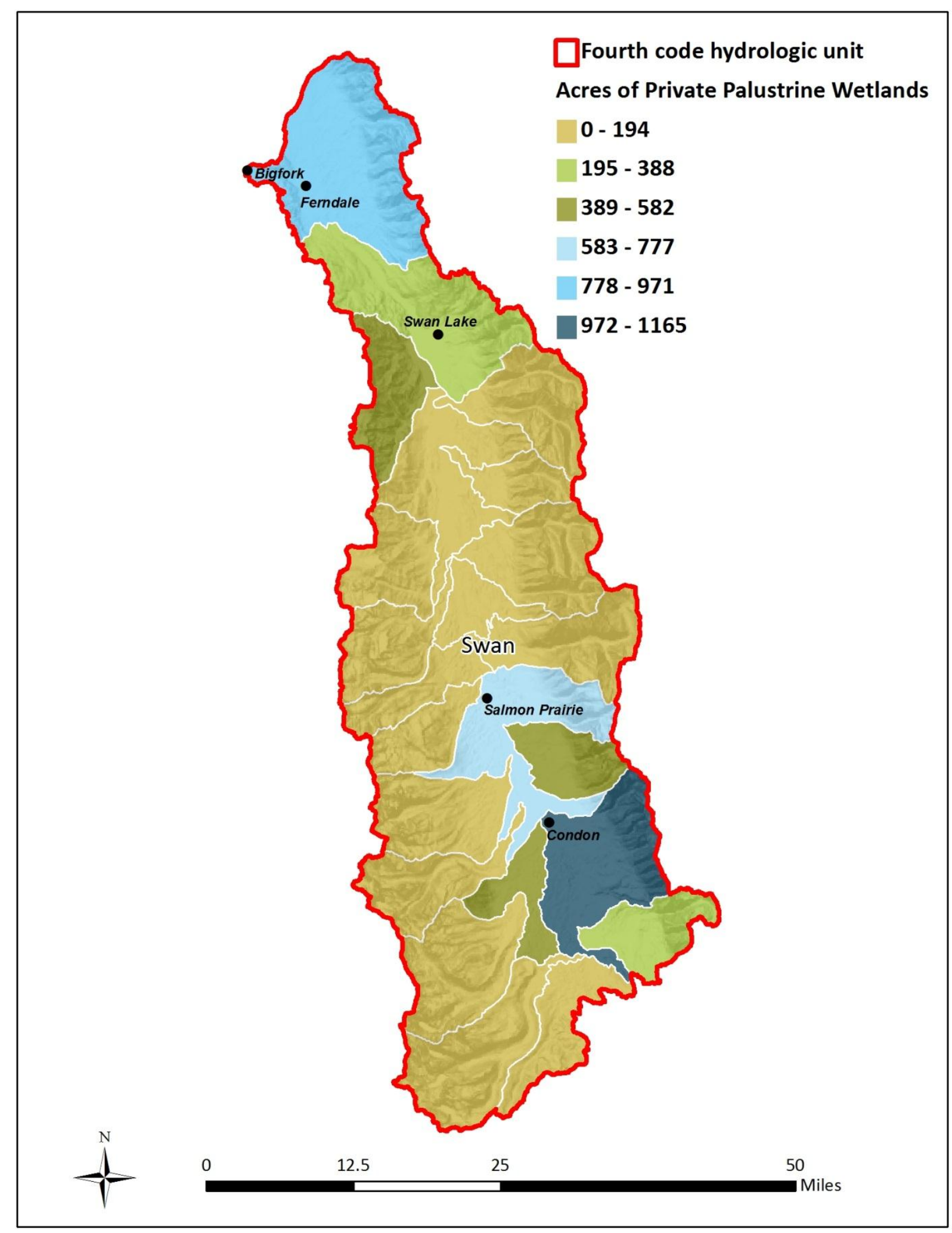

Figure 8. Acres of palustrine wetlands on privately owned lands by sixth code hydrologic unit in the Swan watershed. 


\section{Appendix H. Intermontane Prairie Pothole Ecological System description}

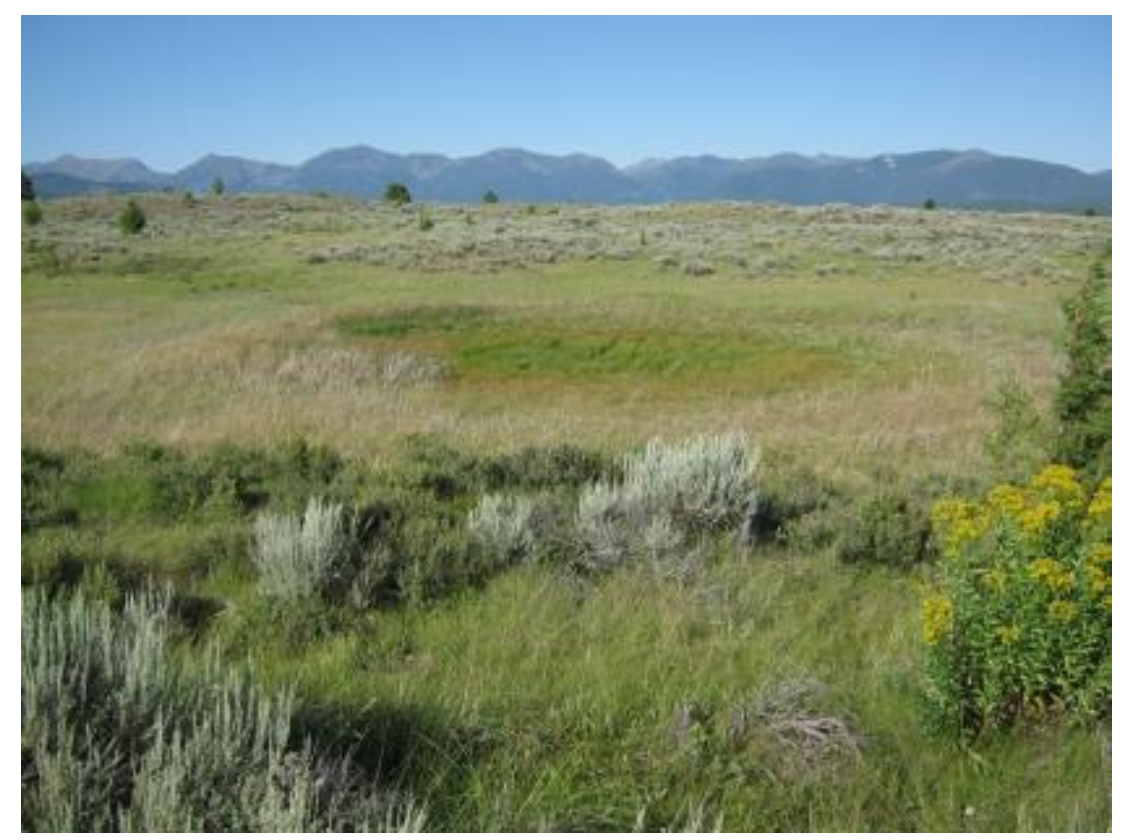

Provisional State Rank: S3

\section{General Description}

The Intermontane Prairie Pothole ecological system occurs in depressions in glaciated valleys of the ecoregions of northwestern Montana, with the highest concentrations found in the Foothill Potholes Level 4 ecoregion north of Ovando and in the Southern Flathead Valley. This system is typically part of a matrix within the Rocky Mountain Lower Montane, Foothill, and Valley Grassland ecosystem. This system is distinguished from the Great Plains Prairie Pothole ecosystem by its location, by its floristic composition, and by hydrology. Unlike wetlands of the Great Plains Prairie Pothole ecosystem, both isolated and connected wetlands within the Intermontane Prairie Pothole ecosystem have only minimal influences from or to local groundwater, and are more likely to exchange water with surrounding uplands than with each other. Water permanence varies depending on wetland size, depth and landscape position, and wetlands of this system can range from temporarily to permanently inundated, although even permanent wetlands may have significant drawdown by the end of the growing season. Vegetation composition varies according to water permanence, but these wetlands are usually dominated by emergent graminoids such as spikerushes (Eleocharis species), sedges (Carex species), rushes (Juncus species) and often, cattails (Typha species) and bulrushes (Schoenoplectus species). In the Flathead valley, reed canarygrass (Phalaris arundinacea) is common, and can become invasive in some wetlands. Zonation is characteristic, with all Intermontane Prairie Potholes having a Low Prairie and Wet Meadow zone, and wetter examples also having a Shallow Marsh, and occasionally, a Deep Marsh zone (sensu Stewart and Kantrud 1971). Because of their limited distribution and their presence on the landscape as wetlandgrassland complexes, wetlands in this ecological system should be regarded as Wetlands of Special Significance. 


\section{Diagnostic Characteristics}

Herbaceous, depression, depressional, flooded or saturated soils, partially isolated

\section{Similar Systems}

- North-Central Interior Freshwater Marsh

- Boreal Freshwater Emergent Marsh

- Alpine-Montane Wet Meadow

- Great Plains Prairie Pothole

\section{Range}

The Intermontane Prairie Pothole ecosystem occurs in depressions in glaciated valleys of the ecoregions of northwestern Montana, with the highest concentrations found in the Foothill Potholes Level 4 ecoregion north of Ovando and in the Ninepipe area of the Southern Flathead Valley. Similar potholes can be found on grassy benches along the North Fork of the Sun River, the Rocky Mountain Front, toe slopes of the Pintler Mountains and in other glaciated valleys where climate favors development of short-grass prairie; however, more field work and analysis will be required to determine whether these similar potholes fall into the current Ecological System

\section{Spatial Pattern}

Matrix

\section{Environment}

Intermontane Prairie Potholes occur in the colluvium and glacial till mantle of valleys in the northwestern Montana mountain ranges. Although the main glacial advance from the cordilleran ice sheet ended in the Flathead Valley, smaller valley glaciers from local mountains formed thick trunk glaciers in these valleys (Hauer et al. 2002). Ice blocks were deposited by retreating glaciers in the Flathead Valley area, forming the kettle depressions in the Ninepipe area, while glacial disintegration created the hummocks and depressions common in the foothill potholes near Ovando. The fine glacial sediments underlying these wetlands consist of glacial "flour" or fine clay, and are generally impermeable. Although the deeper Intermontane Prairie Potholes generally intersect the water table, seasonal and temporary ones are characteristically perched above it (Cook and Hauer 2007). Elevations in the Ninepipe area of the Flathead Valley and the Foothill Potholes ecoregion range from 900 meters to 1,350 meters. Climate is characterized by long, cold winters and moist springs. In the Ninepipe area, climate is distinctly maritimeinfluenced, with the highest precipitation falling between November and January, while the Ovando area receives the greatest amount of precipitation in May and June. 


\section{Vegetation}

Permanently and semipermanent flooded Intermontane Prairie Potholes generally consist of three to four distinct vegetation zones (sensu Stewart and Kantrud 1971): Low Prairie, Wet Meadow, Shallow Marsh, and Deep Marsh. The Deep Marsh zone is characterized by submerged aquatic plants in the open water zone including common hornwort (Ceratophyllum demersum), horned pondweed (Zannichellia palustris), greater bladderwort (Utricularia macrorhiza), and milfoil species (Myriophyllum spp.), as well as floating-leaved plants including lesser duckweed (Lemna minor) and star duckweed (Lemna trisulca), floating pondweed (Potamogeton natans), and slender pondweed (Potamogeton pusillus). The Shallow Marsh zone is typically dominated by hardstem bulrush (Schoenoplectus acutus), cattails (Typha species), narrowleaf bur-reed (Sparganium angustifolium), water smartweed (Polygonum amphibium), common mare's tail (Hippuris vulgaris) and hemlock water-parsnip (Sium suave). The Wet Meadow zone, found in all Intermontane Prairie Potholes, is typically dominated by graminoids including creeping spikerush (Eleocharis palustris), least spikerush (Eleocharis acicularis), common beaked sedge (Carex utriculata), awned sedge (Carex atherodes), foxtail barley (Hordeum jubatum), and boreal mannagrass (Glyceria borealis). In the Ninepipe area, as in many wet meadows in the Flathead Valley, reed canarygrass (Phalaris arundinacea) frequently dominates the wet meadow zone, outcompeting other species. The drier Wet Prairie zone features a mix of graminoids and forbs such as clustered field sedge (Carex praegracilis), tufted hairgrass (Deschampsia cespitosa), wild mint (Mentha arvensis) and silverweed cinquefoil (Argentina anserina). Because many Intermontane Prairie Potholes occur in close proximity to pastures and hayfields, exotic grasses such as intermediate wheatgrass (Elymus hispidus) are common in the Wet Prairie zone.

\section{Alliances and Associations}

\section{Alliances}

- A3807. Eleocharis palustris - Eleocharis acicularis - Eleocharis rostellata Herbaceous Alliance

- A2642. Argentina anserina Low Forb Wet to Dry Meadow Alliance

\section{Associations}

- CEGL001833 Eleocharis palustris Herbaceous Vegetation

- CEGL005825 Argentina anserina Ruderal Herbaceous Vegetation

\section{Dynamic Processes}

Unlike the Great Plains, intermontane valleys like the Flathead and the Blackfoot did not experience a high degree of natural disturbance by large herbivores. However, periodic flooding events, wet-dry climatic cycles and occasional fires operate on both pothole systems in the same 
ways. In dry years, when the aquatic bottoms of shallow water zones are exposed, seeds from both annuals and perennials germinate. When subsequent precipitation floods the depressions, the annuals drown and the perennials survive. Over a series of years the perennials dominate. In the southern Flathead Valley, dry conditions favor the expansion of Phalaris arundinacea into shallow marsh zones; similarly, wet conditions allow it to expand into the Low Prairie zone. In general, species richness can vary considerably among individual intermontane potholes depending on the number of zones present and the degree of grazing in the Low Prairie and Wet Meadow zones.

In contrast to pothole wetlands in the Great Plains, Intermontane Potholes have low groundwater connectivity. Topographic low points on the landscape allow shallow surface-water connections between some wetlands, while high points lead to isolation for others. In both cases, however, Deep and Shallow Marsh areas of these wetlands tend to discharge to the Low Prairie zone in spring, and in summer, as ponded water depth declines, are recharged by water from near-shore soils (Cook and Hauer 2007). Connected wetlands store water longer into the growing season, and show greater primary productivity than isolated wetlands, but there are no notable differences in species diversity, although some species appear to have a greater affinity for connected or isolated wetlands (Cook and Hauer 2007).

\section{Management}

Changes will occur in the plant communities due to climatic conditions and/or management activities as well as the spread of Phalaris arundinacea. Grazing influences at margins or throughout the wetland in drier years can alter the characteristic plant communities. Similarly, agricultural practices may contribute to the spread of exotic species into the Low Prairie zone, and occasionally, into the Wet Meadow zone.

\section{Restoration Considerations}

Intermontane Prairie Potholes in the Ovando area occur mostly in closed basins where the undulating landform does not favor draining or ditching. In other areas, where draining or diversion has occurred, restoration will require reestablishment of the original hydrology, generally by blocking outlets. Once water levels are restored, regrowth and recolonization from dormant rhizomatous root systems of common emergent species can occur within a few years. Livestock grazing should be controlled to allow regrowth, recolonization and resprouting from existing root systems. In areas where Phalaris arundinacea is a problem, aggressive action may be necessary to restore native plant communities. Phalaris arundinacea is undeterred - and in fact may be increased - by burning or mowing. Where flooding can be manipulated, a combination of tillage and flooding may help to control it. Left alone, P. arundinaceae will colonize the areas where sedges and other graminoids would otherwise establish, precluding their successful growth. 


\section{Original Concept Authors}

L. Vance and J. Chutz

\section{Montana Concept Authors}

L. Vance and J. Chutz

Version Date

$11 / 15 / 2015$

\section{Other Classifications:}

National Vegetation Classification Standard

\section{Class}

2. Shrub \& Herb Vegetation

\section{Subclass}

2.B Temperate \& Boreal Grassland \& Shrubland

\section{Formation}

2.B.2 Temperate Grassland \& Shrubland

\section{Division}

D031. Western North American Freshwater Shrubland, Wet Meadow \& Marsh

\section{Macrogroup}

M075. Western North American Montane-Subalpine Wet Shrubland \& Wet Meadow

\section{Group}

G521. Vancouverian \& Rocky Mountain Montane Wet Meadow \& Marsh 


\section{Cowardin Classification System:}

Palustrine Aquatic Bed Permanently Flooded (PABH)

Palustrine Aquatic Bed Semipermanently Flooded (PABF)

Palustrine Aquatic Bed Intermittently Exposed (PABG)

Palustrine Emergent Semipermanently Flooded (PEMF)

Palustrine Emergent Seasonally Flooded (PEMC)

Palustrine Emergent Temporarily Flooded (PEMA)

\section{References}

Cook, B.J. and F.R. Hauer. 2007. Effects of hydrologic connectivity on water chemistry, soils and vegetation structure and function in an intermontane depressional wetland landscape. Wetlands 27(3): 719-738.

Hauer, F.R., B.J. Cook, M.C. Gilbert, E.J. Clairain Jr., and R.D. Smith. 2002. A regional guidebook for assessing the hydrogeomorphic approach to assessing wetland functions of intermontane prairie pothole wetlands in the Northern Rocky Mountains. U.S. Army Engineer Research and Development Center, ERDC/EL TR-02-7, Vicksburg, MS.

Stewart, R. E., and H.A. Kantrud. 1971. Classification of natural ponds and lakes in the glaciated prairie region. U.S. Department of the Interior, U.S. Fish and Wildlife Service, Resource Publication 92, Washington, DC. 